\title{
AVALIAÇÃO DA SUPERFÍCIE RADICULAR APÓS INSTRUMENTAÇÃO MANUAL, ULTRA-SÔNICA E ULTRA- SÔNICA SEGUIDA DE INSTRUMENTAÇÃO MANUAL UTILIZANDO DENTES MINERALIZADOS E DESMINERALIZADOS
}

Dissertação apresentada à Faculdade de Odontologia de Bauru, da Universidade de São Paulo, como parte dos requisitos para obtenção do título de Mestre em Odontologia, área de Periodontia.

Edição Revisada 


\title{
AVALIAÇÃO DA SUPERFÍCIE RADICULAR APÓS INSTRUMENTAÇÃO MANUAL, ULTRA-SÔNICA E ULTRA- SÔNICA SEGUIDA DE INSTRUMENTAÇÃO MANUAL UTILIZANDO DENTES MINERALIZADOS E DESMINERALIZADOS
}

FLÁVIO ROBERTO MACHADO JUSTO

\begin{abstract}
Dissertação apresentada à Faculdade de Odontologia de Bauru, da Universidade de São Paulo, como parte dos requisitos para obtenção do título de Mestre em Odontologia, área de Periodontia.
\end{abstract}

Orientador: Prof. Dr. Euloir Passanezi

(Edição Revisada) 
Justo, Flávio Roberto Machado

J985a Avaliaçăo da superfície radicular após instrumentação manual, ultra-sônica e ultra-sônica seguida de instrumentação manual utilizando dentes mineralizados e desmineralizados. / Flávio Roberto Machado Justo. - Bauru, 2003.

101p.: il.; $30 \mathrm{~cm}$.

Dissertaçāo (Mestrado) - Faculdade de Odontologia de Bauru. Universidade de São Paulo.

Orientador: Prof. Dr. Euloir Passanezi

Autorizo, exclusivamente para fins academmicos e cientificos, a reprodução total ou parcial desta dissertaçăo, por processos fotocopiadores e outros meios eletrônicos.

Assinatura:

Bauru, Março de 2003.

Projeto de pesquisa aprovado pelo Comitê de Ética em Pesquisa da Faculdade de Odontologia de Bauru - Universidade de São Paulo, na reuniăo do dia 19 de agosto de 2002 .

Ofício CEP/FOB-USP nº 05/2002. 


\section{DADOS CURRICULARES}

Nome

Nascimento

$1979-1984$

$1991-1992$

1996

$2001-2003$

Associações:
Flávio Roberto Machado Justo

22 de janeiro de 1959

Santa Mariana - Pr.

Curso de Odontologia - Faculdade de Odontologia da Universidade Estadual de Ponta Grossa.

Curso de Pós-Graduação em Periodontia em nível de Especialização, na Associação Brasileira de Odontologia - Secção Paraná.

Professor da Disciplina de Periodontia do Curso de Odontologia da Universidade Paranaense.

Curso de Pós-Graduação em Periodontia em nível de Mestrado, na Faculdade de Odontologia de Bauru da Universidade de São Paulo.

ABO - Associação Brasileira de Odontologia - Secção do Paraná.

SOBRAPE - Sociedade Brasileira de Periodontia. 


\section{DEDICATÓRIA}

Este trabalho é dedicado às pessoas mais importante da minha vida. Agradeço a Ele por colocar vocês: DARTHHEMIS, ISADORA e BEATRIZ em meu caminho e que sofreram com minha ausência e entenderam a importância deste fato em nossas vidas. Dedico este trabalho com imenso carinho

\footnotetext{
"Você não sabe o quanto eu caminhei pra chegar até aqui percorri milhas e milhas antes de dormir eu não cochilei os mais belos montes escalei nas noites escuras de frio chorei a vida ensina e o tempo traz o tom com a fé do dia a dia encontro a solução [...]"

Cidade Negra
} 


\title{
AGRADECIMEDTOS ESPECIAIS
}

Ao Prof. Dr. Euloir Passanezi

A minha imensa e eterna gratidão pelo tempo dedicado a mim e ao meu trabalho.

Obrigado pelo ensinamento não só da Periodontia mas também pelo conhecimento do que é ser humilde, ético, tenaz entre outros adjetivos que ofazem um grande Mestre.

\author{
"A ética não é uma abstração acadêmica, \\ mas uma das maneiras de ajudar a \\ preservação não só das profissões, \\ como da espécie."
}

Zuenir Ventura 


\section{AGRADECIMENTOS}

Aos meus pais Sérgio (in memorian) e $\mathcal{N} e u s a$ pela formação e os ensinamentos na busca dos ideais.

Aos meus sogros Dalton e Divanir e minhas cunhadas Denise, Daniele e Danusa pelo apoio e por acreditar neste trabalho.

Ao Prof. Dr. Fábio André dos Santos pelo incentivo na busca constante do conhecimento e por me fazer acreditar sempre na Ciência e na Odontologia baseada em evidências científicas

Aos amigos Paulo Davidoff, Edemillson Zarpelon, José Carlos Melo, Gleisi Rieki e todos os colegas que me apoiaram e incentivaram na busca de novos conhecimentos

Ao Prof. Dr. Sebastião Luiz Aguiar Greghi pelo constante incentivo, o meu eterno agradecimento e a Profa $\operatorname{Dr}^{a}$ Adriana Campos Passanezi Sant'ana pela prontidão e simpatia.

Aos funcionários da disciplina de Periodontia, Edilaine, Marcos, Débora e Ivânia pela sua amizade e prestatividade nos momentos em que precisei.

Ao Prof. Eduardo Pfau por manter a disciplina de Periodontia em ordem.

Ao Prof. Dr. Laerte Luiz Bremm pela ajuda e discussão dos temas importantes da Periodontia.

Ao Coordenador do Curso de Odontologia - Campus Umuarama - Prof. Dr. Márcio Grama Hoeppner pela confiança a mim concedida.

Ao Magnífico Reitor da Universidade Paranaense Dr. Cândido Garcia pela ajuda financeira e por incentivar os seus professores a sempre buscar novos conhecimentos.

Aos colegas de Mestrado, João, Neli, Lucinara, Edna, Geraldo, Carrilho, Feis e em especial ao Paulo e a Isa pela amizade que ficou e a ajuda nos momentos difíceis.

À Faculdade de Odontologia de Bauru na pessoa de sua Diretora Prof. Dra Maria Fidela de Lima Navarro por ter abertos as portas desta instituição para que pudéssemos realizar tão brilhantemente nosso trabalho.

Ao Prof. Dr. Newton Expedito de Moraes por dar a oportunidade de nos tornarmos Mestre, pela qual sem sua determinação não estaríamos aqui.

Ao Ricardo Campos, Secretário do Itedes, pela constante disponibilidade e atenção quando necessitamos.

As secretárias do consultório, Claudia, Érica, Adriana, Juliana, Patrícia, Kelly por me agüentarem durante este tempo todo

Ao Edimauro pela ajuda na preparação da parte experimental do trabalho onde seu apoio foi de grande valia.

À Ozania pela colaboração na formatação deste trabalho. 
A todos aqueles que de alguma forma, contribuíram para a realização deste trabalho os meus mais sinceros agradecimentos e muito obrigado. 


\section{SUMÁRIO}

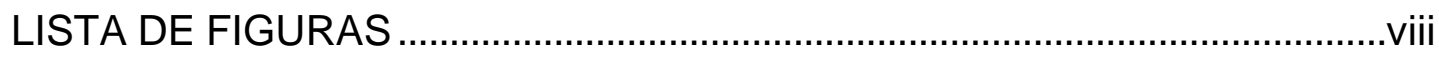

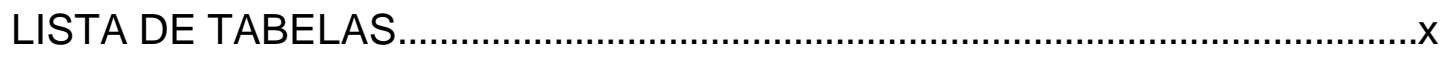

LISTA DE ABREVIATURAS E SÍMBOLOS ……………...............................

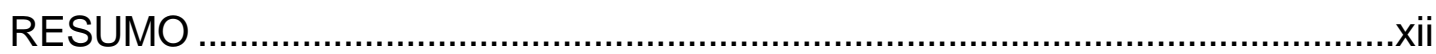

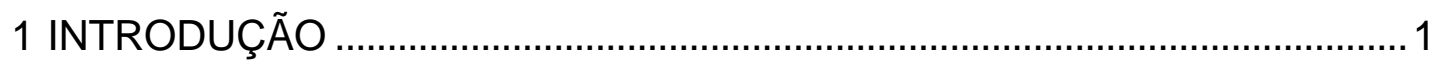

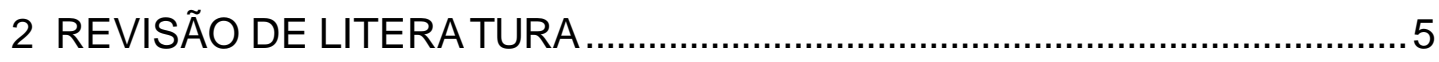

2.1 Importância do Tratamento da Superfície Radicular ...................................... 5

2.2 Efeitos da Instrumentação sobre a Superfície Radicular..........................15

2.3 Efeitos da Desmineralização sobre a Superfície Radicular ........................36

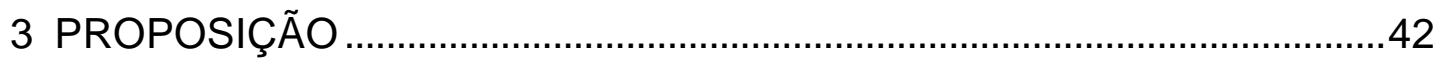

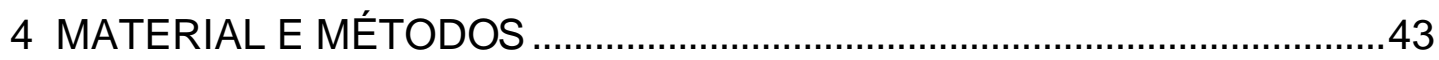

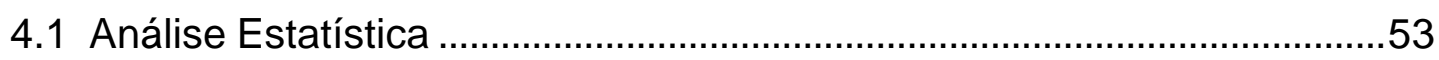

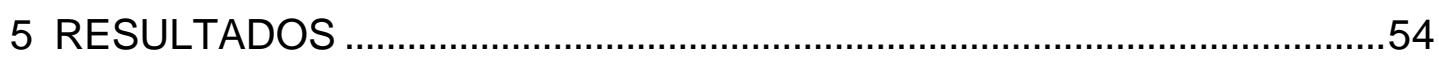

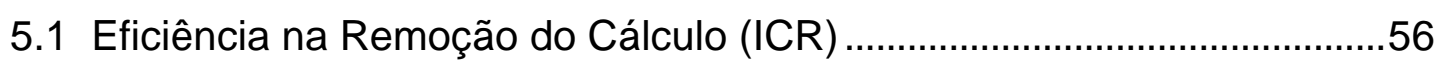

5.2 Avaliação da Rugosidade Superficial (IRS) …………………………....62

5.3 Avaliação da Perda de Substância Dentária (IPSD) ...................................68

5.4 Correlação entre os índices ICR , IRS e IPSD ………………………....73

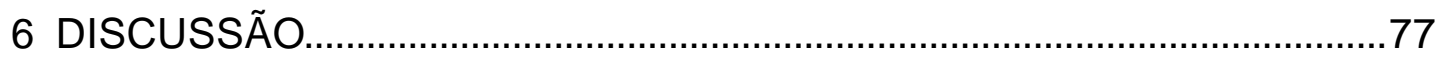

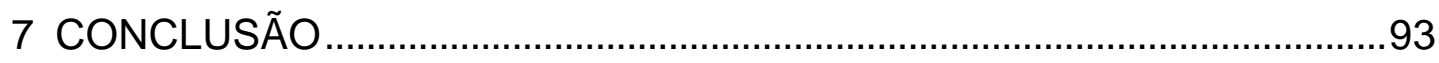

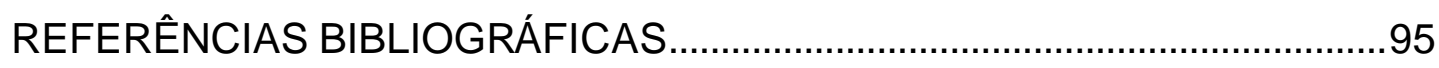

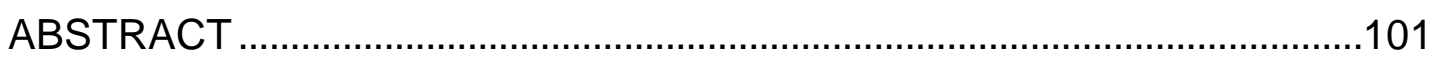




\section{LISTA DE FIGURAS}

FIGURA 1 - Vista do objeto de estudo mostrando o corte no longo eixo do dente antes da instrumentação para evitar acúmulo excessivo de sujeira na superfície a ser instrumentada e manutenção da coroa intacta com intuito de sugerir a possibilidade de melhor apoio e copiar a situação clínica possível.

FIGURA 2-Vista do bloco de trabalho demonstrando a fixação do terço apical em cápsulas de amálgama com resina composta (Concise) deixando a superfície a ser instrumentada livre

FIGURA 3-Vista lateral da superfície mostrando sulcos produzidos lateralmente às áreas a serem raspadas delimitando a quantidade de superfície a ser instrumentada e o tamanho do futuro fragmento ( 5 a $7 \mathrm{~mm}$ ).

FIGURA 4 - Vista do objeto a ser instrumentado estabilizados na prensa Morsa, para facilitar os movimentos de instrumentação. 46

FIGURA 5 - Vista demonstrando forma de apoio e adaptação da lâmina do instrumento e movimentos de tração no sentido ápicocoronário utilizando cureta Gracey 5/6.

FIGURA 6 -Vista demonstrando o modo de aplicação da ponta do instrumento (US) sobre a superfície radicular

FIGURA 7-Vista dos fragmentos obtidos após seccionamento com brocas, e colados no corpo de prova, prontos para serem serem impregnados com ouro

FIGURA 8 -Vista dos fragmentos impregnado com ouro e pronto para análise e obtenção de imagem em MEV

FIGURA 9 -Grupo Controle .54

FIGURA 10 - Interpretação do Kappa .55

FIGURA 11 - ICR (Índice de Cálculo Residual) . .59

FIGURA 12 - Postos médios das medianas dos escores do ICR. 62

FIGURA 13 - IRS (Índice de Rugosidade de Superfície) .65

FIGURA 14 - Postos Médios das Medianas dos Escores do IRS .68 
FIGURA 15 - IPSD (Índice de Perda da Substância Dentária) ..........................70

FIGURA 16 - Postos Médios das Medianas dos Escores do IPSD ..................73

FIGURA 17 - Correlação entre os Valores das Medianas dos Escores do

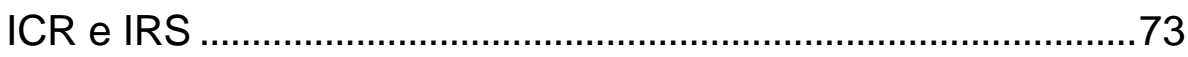

FIGURA 18 - Correlação entre os Valores das Medianas dos Escores do

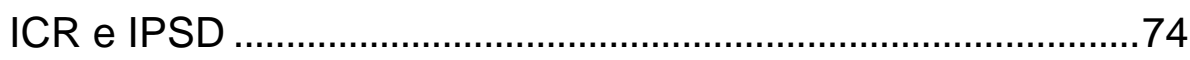

FIGURA 19 - Vista da instrumentação com US isoladamente denotando presença de cálculo (vide setas) o qual demonstra a pouca pouca perda de substância dentária - Aumento 100X .75

FIGURA 20 - Correlação entre os Valores das Medianas dos Escores do

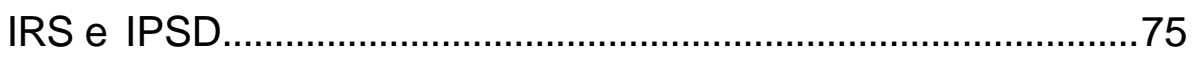

FIGURA 21 - Comparação entre IRS e IPSD ………………………………...76 


\section{LISTA DE TABELAS}

TABELA 1 - Concordância intra-examinador para o Índice de Cálculo Residual (ICR)

TABELA 2-Concordância intra-examinador para o Índice de Rugosidade Superficial (IRS)

TABELA 3-Concordância intra-examinador para o Índice de Perda de Substância Dentária (IPSD) .56

TABELA 4 - Valores de mediana, mínimo e máximo para o ICR

TABELA 5-Soma dos postos e postos médios para os grupos experimentais

TABELA 6 - Resultados do teste de comparações múltiplas de Dunn para os grupos experimentais 58

TABELA 7 - Valores de mediana, mínimo e máximo para o IRS .62

TABELA 8-Soma dos postos e postos médios para os grupos experimentais .63

TABELA 9 - Resultados do teste de comparações múltiplos de Dunn para os grupos experimentais .64

TABELA 10 - Valores de mediana, mínimo e máximo para o IPSD .68

TABELA 11-Soma dos postos e postos médios para os grupos experimentais .69 


\section{LISTA DE ABREVIATURAS E SÍMBOLOS}
AAP - Academy American of Periodontology
C - Cemento
Ca - Cálculo dental
D - Dentina
DP - Doença Periodontal
EDTA - Ácido Etileno Diamino Tetracético
HGF - Human Gingival Fibroblats
ICR - Índice de Cálculo Residual
IGF-I - Fator de Crescimento Insulínico-I
IPSD - Índice de perda da Substância Dentária
IRS - Índice de Rugosidade da Superfície
JEC - Junção esmalte-cemento
LPS - Lipopolisacarídeos
MEM -Meio Essencial Mínimo
MEV - Microscopia Eletrônica de Varredura
Ns - Não significante
$\mathrm{Pa} \quad$ - Força Pascal
PDGF - Fator de Crescimento Derivado de Plaquetas
S - Significante
TGF - Fator de Crescimento Transformador-beta
US - Ultra-Som 


\section{RESUMO}

O presente trabalho avaliou o efeito do tratamento da superfície radicular por meio da instrumentação com curetas, US e US seguido de curetas, utilizando dentes mineralizados e desmineralizados conjugando a utilização de cítrico e tetraciclina. As superfícies dentais foram analisadas em MEV por um único examinador, sendo utilizados 66 dentes unirradiculares com presença de cálculo indicando doença periodontal. Os dentes foram divididos em 6 grupos experimentais com 10 dentes cada e um grupo controle com 6 dentes sem tratamento. O protocolo de tratamento dos grupos seguiu a seguinte orientação: grupo 1- dentes mineralizados instrumentados com curetas; grupo 2- dentes mineralizados instrumentados com US; grupo 3- dentes mineralizados instrumentados com US, seguindo-se instrumentação com curetas; grupo 4- dentes instrumentados com curetas, desmineralizados e novamente instrumentados com curetas; grupo 5 - dentes instrumentados com US, desmineralizados e novamente instrumentados com US; e, grupo 6- dentes instrumentados com US, desmineralizados e novamente instrumentados com curetas. Foram analisadas a quantidade de cálculo residual (ICR), a rugosidade da superfície radicular (IRS) e perda da substância dentária (IPSD). Os resultados demonstraram diferenças estatísticas significativas quanto ao ICR do grupo 2 em relação aos grupos 3 , 4 e 6 e do grupo 5 com os grupos 4 e 6 ; quanto ao IRS houveram diferenças estatísticas significativas entre o grupo 2 e os grupos 1, 4 e 6 e entre o grupo 5 e os grupos 1 e 6; quanto ao IPSD, observou-se que não houve diferenças estatísticas significativas entre os grupos. $\mathrm{O}$ uso de curetas isoladamente ou após US parece melhor se ajustar aos critérios de preparo adequado da raiz, em função dos parâmetros avaliados. 


\section{INTRODUÇÃO}

Para o restabelecimento da saúde, na terapia periodontal é fundamental a remoção da placa dentobacteriana e seus produtos tóxicos, bem como do cálculo dental e cemento contaminado, sendo que o cálculo deve ser removido supra e subgengivalmente, pois tem como característica a capacidade de abrigar microorganismos e seus produtos e a impossibilidade de ser removido pelos meios convencionais de higiene bucal.

Em 1965 LOE; THEILADE; JENSEN ${ }^{39}$, observaram o desenvolvimento de gengivite em pacientes saudáveis pela suspensão dos cuidados de higiene bucal e as subseqüentes mudanças produzidas na microbiota indígena, constante de aumento no número de microrganismos na área gengival e variações na composição da microbiota. Por isso consideraram de suma importância o controle desses fatores, que se consegue por meio do controle de placa e na presença de depósitos calcificados da instrumentação radicular.

A remoção mecânica daqueles depósitos e estruturas contaminadas pode ser conseguida por meio de raspagem e aplainamento com instrumentos manuais (curetas) ou com a utilização de aparelhos ultrasônicos segundo a $A A P^{01}$. Qualquer que seja o instrumento usado, considerase que a instrumentação deve produzir superfície radicular compatível com reparação dos tecidos periodontais que se caracteriza ao exame clínico por meio de lisura da superfície radicular ${ }^{63,57,67,24,44}$. Aliás, a lisura da superfície radicular é realmente o único indicador disponível para avaliar o sucesso imediato da remoção do cálculo e cemento contaminado, até que surja outro método mais preciso.

No entanto, o aspecto da superfície radicular após os diferentes tipos de instrumentação apresentam diferenças com relação à textura radicular, sendo amplamente aceita a dificuldade de remoção de todas as concreções, calcificadas ou não, das superfícies radiculares utilizando raspagem e aplainamento radicular.

Outro ponto importante nos dias atuais refere-se à quantidade de remoção do cemento contaminado ${ }^{47,04,46}$. A capacidade da superfície radicular 
exposta à DP de incorporar material tóxico e passar por inúmeras mudanças histológicas, fisiológicas, químicas e imunoquímicas, foi proposta por RUBEN e SHAPIRO ${ }^{54}$, em 1978, com o que o cemento pode perpetuar os efeitos destrutivos da doença periodontal (DP), agindo como reserva de materiais potencialmente destrutivos ${ }^{43}$.

ALEO et al. ${ }^{03}$ (1974), demonstraram que raízes contaminadas, contêm substâncias tóxicas capazes de deprimirem o crescimento de fibroblastos em cultura de células.

Essas substâncias foram identificadas como endotoxinas, podendo ser extraídas por tratamento com fenol. Essas observações foram confirmadas por FINE et al.. ${ }^{22}$ (1980), que enfatizaram o fato da substância endotoxina ser resistente à autoclavagem e não detectável clinicamente.

Portanto, é sugestivo que raspagem e aplainamento radicular sejam procedimentos de relevância na remoção de produtos tóxicos incorporados à superfície ou camadas internas do cemento, de modo a processar aumento da cementogênese e compatibilidade biológica da raiz para adesão de fibroblastos $^{33,17,25,13,05,56,29}$.

Como relatado anteriormente, a raspagem e o aplainamento radicular podem ser efetuados por instrumentos manuais ou ultra-sônicos e vários estudos têm sido conduzidos para avaliar a efetividade desses dois métodos de instrumentação. Em relação à superfície radicular, alguns autores ${ }^{30,11,07}$, concluíram que o uso de curetas produz superfície mais lisa que a observada após o uso de ultra-som (US), enquanto WOODRUF et al. ${ }^{66}$ (1975), relataram resultado semelhante para os dois métodos de raspagem. Segundo JONES et al. ${ }^{32}$ (1972) não há diferença na eficiência em remover cálculo da superfície dentária com os instrumentos acima propostos, bem como, o instrumento ultra-sônico provoca menos dano à superfície radicular.

Dentro dessa linha de raciocínio, tem-se proposto o uso de US sob o argumento de que deixaria a superfície lisa com menos remoção de estrutura ${ }^{41,48,53}$, enquanto outros têm considerado que, apesar de remover mais estruturas, as curetas produzem superfície mais lisa ${ }^{64,40}$.

Por outro lado, o US pode ser tão efetivo quanto o instrumento manual em remover cálculo, mas não o é na produção de superfície plana, 
por isso STENDE; SCHAFFER ${ }^{61}$, consideraram que o US pode ser usado na remoção inicial do cálculo, completando-se o procedimento com cureta para promover planificação da raiz, com o que concordou GARRETT ${ }^{24}$ em 1977. Para este autor o US produziria remoção de cálculo mais rapidamente e os instrumentos manuais completariam, com sua habilidade em promover melhor remoção do cemento comprometido pela doença periodontal..

É interessante observar a escassez de trabalhos analisando a efetividade da associação de diferentes meios de instrumentação a partir dessa época. Entretanto, outras vantagens poderiam advir como maior conforto ao paciente pela diminuição no tempo de trabalho ${ }^{16}$. Cite-se ainda, que a instrumentação radicular por meio de suas várias modalidades promove a formação de "smear layer", a qual, segundo BLOMLOF ${ }^{09}$ (1997), inibe a adesão, a migração e a proliferação celular sobre a superfície radicular, pois este material assim como o cemento doente, contém produtos citotóxicos provenientes de bactérias. Portanto a presença da "smear layer", reduz significantemente a reparação do periodonto, impedindo a ação celular e dificultando a nova inserção de tecido conjuntivo.

Por outro lado, a efetividade da instrumentação radicular em eliminar as endotoxinas tem sido estudada exaustivamente, sendo aceito que tanto a instrumentação manual como a ultra-sônica podem diminuir a quantidade de endotoxinas nas superfícies radiculares ${ }^{44,13,60}$.

Todavia, considerando as dificuldades e limitações da remoção total das bactérias e suas toxinas ${ }^{02}$, o emprego desses procedimentos pode não levar ao alcance dos objetivos descritos acima, razão pela qual se tem proposto a utilização de agentes químicos que promovam a desmineralização, como por exemplo, o ácido cítrico ${ }^{62}$. Parece, importante que o emprego de agentes desmineralizantes pode facilitar a obtenção de superfície radicular mais uniforme e biocompatível, uma vez que a remoção de fatores capazes de agredirem a estrutura promove superfície adequada para a cicatrização dos tecidos moles circunjacentes.

Vê-se, pois, que a despeito da importância da adequacidade biológica da raiz para expressão da saúde periodontal, ainda se fazem necessários 
estudos na busca de melhores esclarecimentos sobre a abordagem terapêutica das raízes de dentes periodontalmente envolvidos. 


\section{REVISÃO DE LITERATURA}

Para melhor entendimento e facilitar a leitura do trabalho, o presente capítulo será dividido em três partes:

\subsection{Importância do Tratamento da Superfície Radicular}

Ao que parece, um dos primeiros trabalhos de tratamento da raiz que enfatizou a importância do seu preparo adequado, visando algum controle de fatores bacterianos, foi o de $\mathrm{KROMER}^{36}$ em 1962, quando mencionou que a obtenção de regeneração periodontal em procedimentos de enxertos ósseos homógenos requeria a dotação de superfície radicular lisa e dura, implicando com isto uma superfície "estéril".

SELVIG ${ }^{58}$, em 1966, investigou mudanças patológicas em nível ultraestrutural localizadas próximas à superfície da raiz de dentes envolvidos com DP em humanos. Notou uma série de mudanças definitivas, resultando na perda completa das fibras de tecido conjuntivo inseridas no cemento. A destruição das fibras periodontais foi caracterizada pela separação do componente fibrilar, seguida pela ruptura longitudinal das fibrilas colágenas, processo esse iniciado a alguma distância da superfície do cemento. Com isso, microfibrilas não estriadas foram expostas em quantidades crescentes. O estágio mais avançado da degradação do colágeno ocorreu imediatamente adjacente ao epitélio juncional, onde o espaço intercelular apresentou feixes de filamentos não estriados e resíduo granular, mas não fibrilas colágenas típicas. Os produtos de degradação possivelmente contribuem para a formação de cutícula secundária no cemento. Em alguns espécimes foram achadas alterações no interior do cemento, consistindo da remoção de cristais minerais, bem como modificação e possivelmente remoção da matriz colágena em área até $18 \mu \mathrm{m}$ adentro da superfície do cemento. As lesões relativas ao cemento localizadas no fundo da bolsa periodontal e na região da inflamação, sugerem que a alteração da matriz orgânica é causada pelos 
agentes responsáveis pela deterioração das fibras periodontais, enquanto os cristais minerais são removidos pelo processo de descalcificação.

Com o objetivo de estudar a ultra estrutura do cemento e a condição da superfície radicular envolvida com doença periodontal, HERTING ${ }^{27}$, em 1967, realizou estudos sobre o seu conteúdo mineral em secções ultra finas de dentes envolvidos com doença periodontal, analisadas em microscopia eletrônica e tomando como base os resultados obtidos de dentes periodontalmente saudáveis. Verificou que, quando o tecido periodontal saudável circunda a raiz, todas as camadas de cemento estão estruturadas normalmente; na matriz colágena são depositados o mesmo tipo de cristal e da mesma espessura, seguindo o mesmo padrão de epitaxia. A superfície do cemento é lisa $\mathrm{e}$ as fibrilas colágenas atravessam 0 cemento desmineralizado, alcançando os tecidos periodontais. Já o cemento exposto à luz da bolsa periodontal apresenta-se com a superfície coberta por camada de bactérias em forma de membrana, resíduos bacterianos e substâncias não definidas na microscopia eletrônica. Abaixo dessa camada e também sobre a superfície não coberta, a estrutura de cristal da camada superior do cemento pode estar densa ou menos densa do que o normal. Após dissolução e recristalização, outras formas e tamanhos de cristais podem se desenvolver e a orientação dos cristais para as fibrilas colágenas podem diferir. Estes depósitos bacterianos permanecem livres de minerais ou podem formar cálculo pela deposição mineral inter e intrabacteriana. Este material projetase da parte inorgânica do cemento, ou é introduzido do exterior. O cálculo pode estar levemente ou fortemente aderido ao tecido cementário e substâncias contendo ambos, cemento e cálculo, podem se desenvolver. A superfície da camada de cemento alterado ou dos depósitos de cálculo está dividida ou fragmentada, com ausência de fibrilas colágenas. Finalmente, o cemento pode estar alterado e destruído por cárie. Por meio de análise em MEV o autor concluiu que a capacidade funcional ou habilidade funcional do cemento pode ser restaurada somente se coberturas, camadas superiores (superficiais) alteradas de cemento e bactérias invasoras do tecido forem removidas por curetagem vigorosa, de maneira que o cemento normalmente estruturado esteja na superfície. 
Com o intuito de avaliar a aderência do cálculo na superfície radicular com microscopia óptica, em 1969 MOSKOW $^{42}$ utilizou 135 secções selecionadas de dentes humanos intactos e suas estruturas periodontais adjacentes. Todos os espécimes escolhidos demonstraram depósitos de placa e cálculo sobre os dentes. O cemento apareceu separado da superfície dentinária em graus variados, porém de maneira distinta dos artefatos de ruptura, muitas vezes criados nessas áreas durante o processamento dos tecidos para exame histológico. Dentro do espaço criado pela fratura do cemento, freqüentemente se observou acúmulo de placa e cálculo e muitas vezes o referido espaço estava preenchido por cálculo em sua totalidade. Em locais em que houve completa fragmentação do cemento, foi freqüente encontrar cálculo aderido diretamente à dentina. Quer o cemento seja fraturado na porção exposta à bolsa periodontal, quer a fragmentação seja profunda dentro do periodonto, a separação é mais comumente encontrada na junção cemento-dentina. As implicações clínicas deste fenômeno em relação à remoção de cálculo são evidentes por si só. $O$ autor concluiu que o aprisionamento de cálculo nas áreas de separação do cemento dificulta a completa remoção do cálculo, e assim meticuloso aplainamento radicular até a dentina intacta é requerido quando a remoção completa do cálculo é o objetivo, considerando que o cálculo pode atuar como nicho de depósitos adicionais.

Apenas em 1971, HATFIELD; BAUMHAMMERS ${ }^{26}$ observaram que a superfície radicular de dentes periodontalmente envolvidos induziram processos de aversão em células epiteliais.

Em 1974, ALEO et al. ${ }^{03}$, utilizando ensaio de Limulus Lysate para endotoxinas mostraram que superfícies radiculares envolvidas com doença periodontal, contêm endotoxina capaz de deprimir o crescimento e viabilidade das células em cultura de fibroblastos. Essas endotoxinas foram extraídas das raízes com solução de fenol a $45 \%$ em água fenol e mostraram-se resistentes à autoclavagem. Assim concluíram que esse material é realmente endotoxina e que o cemento exposto ao ambiente da bolsa abriga este material. 
Em outro trabalho "in vitro", em 1975, ALEO et al. ${ }^{03}$, compararam a adesão e o crescimento de fibroblastos de gengiva humana sobre superfícies radiculares expostas à doença periodontal (DP) e tratadas de modo a formar 3 grupos: a) tratados com remoção mecânica de cemento até a dentina em uma metade da raiz; b) tratados com fenol a $45 \%$ em água a $60^{\circ}$ por 1 hora, seguida por lavagens múltiplas com etanol a $70 \%$; e c) raízes que não receberam nenhum tipo de tratamento. Dentes não irrompidos ou sem evidência de DP foram removidos cirurgicamente e serviram de controle. Todos os dentes foram autoclavados, plaqueados com células e incubados por 24 e 48 horas. Após a incubação, alguns espécimes foram corados para visualização grosseira das células aderidas e outros processados para análise em MEV. Enquanto os dentes controle permitiram a adesão celular sobre toda a superfície radicular, as raízes não tratadas apresentaram pouca ou nenhuma adesão celular. Quando a endotoxina foi removida da raiz, tanto mecanicamente através da raspagem e aplainamento ou pela utilização de fenol a $45 \%$, as células aderiram e cresceram normalmente sobre toda a superfície radicular. Ao final de 48 horas de incubação as células estavam sobrepostas demonstrando muitos pontos de inserção sobre as superfícies. Correlacionando estes dados a uma situação "in vivo", os autores comentaram que o sucesso clínico dependeria da completa remoção dos materiais tóxicos do cemento doente ou remoção do cemento em si.

Com a finalidade de verificar a efetividade do aplainamento radicular "in vitro" na remoção de endotoxinas bacterianas das raízes de dentes com envolvimento periodontal, JONES; O'LEARY ${ }^{33}$ desenvolveram estudo em serem humanos em 1978. As amostras foram divididas em 5 grupos de tratamento como se segue: grupo com superfícies radiculares aplainadas com curetas afiadas na área subgengival proximal; outro grupo com instrumentação supragengival; o terceiro grupo constou de dentes com superfícies não tratadas, inclusive com cálculo; grupo de superfícies tratadas "in vitro" por remoção do cálculo visível ainda que deixando o cemento intacto; e amostras de dentes não irrompidos e sem envolvimento de DP. As amostras preparadas foram submetidas à avaliação de endotoxinas através do "Limulus Lysate Test" para determinar a quantidade de endotoxinas em 
cada grupo. Este teste é baseado na reação enzimática de quantidades observáveis de endotoxinas com o reagente Lysate. Os resultados demonstraram que somente raspagem sem aplainamento proporcionaram valores de endotoxina mais altos que os encontrados em superfícies radiculares saudáveis. Já o aplainamento radicular foi capaz de tornar superfícies radiculares doentes tão livres de endotoxinas detectáveis quanto as superfícies radiculares de dentes não irrompidos. O trabalho mostrou com clareza que a raspagem isolada não foi suficiente para remover toda a endotoxina da raiz, enquanto que o aplainamento radicular produziu superfície similar as superfícies radiculares não envolvidas no que diz respeito à presença de endotoxinas. Foi sugerido que somente raspagem é insuficiente para promover reinserção periodontal, mas o aplainamento radicular é adequado para produzir superfície radicular compatível com saúde periodontal.

WIRTHLIN et al. ${ }^{65}$, em 1979, propuseram comparar o conteúdo mineral do cemento sadio com o do cemento exposto à DP. As amostras de superfícies radiculares foram obtidas por método de biópsia abrasiva. Comparando os resultados dos 2 grupos houve diferença significativa nos componentes minerais ( $\mathrm{Ca}, \mathrm{Mg}, \mathrm{P}$ e F), ou seja, superfícies contaminadas continham maior conteúdo mineral, cujas implicações clínicas foram consideradas desconhecidas, exceto pelo fato de poder ser favorável no controle da hipersensibilidade cervical.

NISHIMINE; O'LEARY44, em 1979, realizaram estudo “in vivo" para determinar a efetividade da instrumentação manual e ultra-sônica relacionada à remoção de endotoxinas de superfícies radiculares. Um grupo de 46 dentes foi raspado com curetas até que a superfície estivesse lisa e dura. Outros 46 dentes foram submetidos à instrumentação ultra-sônica, buscando as mesmas características de superfície que o grupo anterior. Um $3^{\circ}$ grupo foi formado com 46 dentes com DP e sem nenhum tipo de tratamento e um 4응 grupo com 31 dentes não irrompidos e/ou intraósseos. As toxinas foram avaliadas pelo método Limulus Amebocyte Lysate. O valor médio encontrado no grupo raspagem com cureta foi de $2,09 \mathrm{ng} / \mathrm{ml}$, no grupo US foi de 16,8 $\mathrm{ng} / \mathrm{ml}$, no grupo sem tratamento $169,5 \mathrm{ng} / \mathrm{ml}$, enquanto no grupo de dentes 
não irrompidos foi de $1,46 \mathrm{ng} / \mathrm{ml}$. Os autores concluíram que instrumentação manual com curetas, realizada meticulosamente, resulta na mesma quantidade de toxinas residuais observadas nas superfícies radiculares de dentes sem envolvimento com DP, e que a instrumentação manual foi mais efetiva que o US para remoção de endotoxinas da superfície radicular. Entretanto salientaram que não houve prova irrefutável de se tratar de endotoxina.

A contaminação do cemento envolvido periodontalmente por substâncias bacterianas como lipopolissacarídeos (LPS) tem sido considerada uma razão fundamental para o aplainamento radicular conforme DALY et al. ${ }^{18}$, em 1982. Por isso realizaram estudo para avaliar a presença e localização de LPS dentro de cemento envolvido de 36 dentes com doença periodontal em relação ao cemento não envolvido de 2 dentes controle. As amostras de cemento periodontalmente envolvido e não envolvido foram fixadas e examinadas sob microscopia óptica. Cemento de 12 dentes envolvidos periodontalmente exibiram forte processo de fixação penetrando de 3 a 7 öm dentro da estrutura do cemento coberto por placa, processo este não observado no cemento não envolvido, sugerindo possível origem bacteriana. Grânulos de lípideos foram observados dentro de depósitos de placa, porém não em cemento não envolvido, novamente sugerindo sua possível origem bacteriana. Amostras fixadas revelaram a presença de depósitos microbianos em defeitos de superfície e da junção cemento-dentina , assim como, penetração de microganismos no interior do cemento na ausência de defeitos superficiais. Os resultados indicaram que embora lipídeos e polissacarídeos de possível origem bacteriana possam estar presentes numa zona superficial de $10 \mu \mathrm{m}$ de cemento envolvido, o achado de depósitos bacterianos até o nível da junção cemento-dentina sugere que todo cemento envolvido periodontalmente deveria ser removido durante o aplainamento, para conseguir uma superfície radicular livre de contaminação bacteriana.

NAKIB et al. ${ }^{43}$, em 1982, propuseram-se em seu estudo a analisar, 1) se há penetração de endotoxina bacteriana na superfície radicular exposta ou não à DP, e 2) se a limpeza da superfície radicular pela escovação é capaz 
de remover endotoxinas. Utilizaram 32 dentes, sendo $20 \mathrm{com}$ raiz contaminada e $12 \mathrm{com}$ raiz sadia, avaliando os espécimes pelo método autoradiográfico e por imunofluorêscencia. As amostras foram imersas em endotoxina (E. coli) em várias concentrações durante 2 a 12 semanas, para determinar o alcance da penetração de endotoxina no interior da superfície radicular. Os resultados indicaram que a endotoxina pode aderir ao cemento de dentes envolvidos ou não com DP e que a aderência da endotoxina parece ser tênue, uma vez que ela foi quase totalmente removida pela escovação. Com isso consideraram que a endotoxina localiza-se na superfície do cemento e sugeriram que a remoção excessiva de modo intencional durante $\mathrm{o}$ aplainamento radicular com 0 intuito de eliminar endotoxinas da raiz exposta à DP não é justificada. Contudo chamou a atenção para a possibilidade de que outros contaminantes bacterianos com os mesmos ou maiores efeitos citotóxicos poderiam estar presentes e não terem sido detectados pelos métodos usuais por serem termolábeis.

Com o intuito de estudar a viabilidade e a adesão de fibroblastos de gengiva humana (HGF) sobre superfícies radiculares que receberam diferentes tratamentos, em 1983, COGEN et al. ${ }^{15}$ em 1983, utilizaram dentes extraídos por motivo de doença periodontal e dividiram a amostra em 4 grupos: 1) sem tratamento; 2) aplicação de ácido cítrico sem raspagem; 3) somente raspagem e aplainamento e 4) raspagem e aplainamento mais aplicação de ácido cítrico. Todos os espécimes foram autoclavados para prevenir a contaminação bacteriana da cultura. Após incubação de 3 ou 24 horas as células foram coradas ou marcadas com Cromo radioativo para realização do teste de viabilidade celular. Essas duas análises demonstraram que os diferentes tratamentos radiculares não produziram efeito adverso na viabilidade dos fibroblastos, ou seja, a esterilização dos fragmentos foi eficiente em não contaminar as culturas. Para análise da adesão e crescimento celular, 50000 células foram plaqueadas sobre os fragmentos e incubadas por 72 horas.Os espécimes sem tratamento ou tratados somente com ácido cítrico não apresentaram células aderidas sobre a superfície, enquanto as raízes que foram somente raspadas e aplainadas seguidas ou 
não da aplicação de ácido cítrico, permitiram igualmente a adesão e o crescimento dos fibroblastos.

Ainda nesse ano, O'LEARY; KAFRAWY ${ }^{47}$ analisaram a efetividade de 3 tipos de instrumentos manuais habitualmente empregados para remoção de cemento radicular de dentes afetados periodontalmente. Utilizaram 36 dentes, nos quais todo cálculo visível foi removido pela aplicação de 50 golpes de cureta como limite de instrumentação viável em situação clínica, conforme determinação prévia por meio de estudo piloto.Os instrumentos utilizados foram: raspador (Jaquete n-30/33), cureta (Gracey nำ-2) e cureta (IU no13). A quantidade de cemento residual foi avaliada histologicamente em 3 níveis (cervical, terço médio e terço apical). Os resultados demonstraram que em nenhuma amostra o cemento foi inteiramente removido nos 3 níveis, sendo o terço apical aquele que apresentou a maior quantidade de cemento residual. Os autores concluíram que a remoção total de cemento não é objetivo clínico a ser alcançado com os instrumentos empregados.

Ao avaliarem diferentes métodos de desintoxificação radicular GILMAN; MAXEY ${ }^{25}$, em 1986, citaram que a compatibilidade biológica dos tecidos periodontais circunjacentes à raiz dental seria o objetivo básico da terapia periodontal, pois a citotoxicidade dos sub-produtos bacterianos aderidos à raiz, interfere com a compatibilidade dos tecidos moles e duros. $A$ remoção dos fatores citotóxicos por várias técnicas de descontaminação radicular, poderia ajudar a atingir o objetivo de tornar a superfície radicular biologicamente aceitável ao periodonto. Os autores utilizaram US (Cavitron) e Cavitron e Prophy-jet, na busca de descontaminar a superfície radicular doente, além de um grupo controle com dentes contaminados por DP e não tratados. Após tratamento, a avaliação com cultura de células nas amostras de superfícies radiculares não tratadas mostraram que estas superfícies foram totalmente incompatíveis com crescimento celular, enquanto 0 tratamento com Cavitron e Prophy-jet mostrou melhores resultados de crescimento e vitalidade de fibroblastos. Assim concluíram que nova inserção de fibroblastos à superfície radicular dependerá da completa remoção de materias tóxicos do cemento doente e/ou completa remoção do cemento em si. 
ADRIAENS et al..$^{02}$, em 1988, realizaram estudo bacteriológico em dentes humanos livres de cárie, para determinar o número e distribuição das bactérias que invadem a dentina de raízes periodontalmente doentes. $O$ estudo demonstrou que um número significativo de bactérias está presente nos vários segmentos da dentina radicular de dentes com doença periodontal e livres de cárie. Embora a remoção de toxinas bacterianas associadas ao cemento possa ter importância para os resultados da terapia periodontal, foi demonstrado que mesmo a remoção mecânica de todo cálculo subgengival é freqüentemente impossível, tendo em vista que as estruturas anatômicas da raiz e as lacunas de reabsorção radicular que estão repletas de bactérias, são inacessíveis para a instrumentação. Fica claro que as bactérias que invadem profundamente a dentina radicular como foi demonstrado neste estudo, são ainda mais inacessíveis à instrumentação mecânica. Sendo assim, a raspagem e aplainamento agressivos poderiam ser contraproducentes para se atingir saúde periodontal. O estudo sugeriu que a contaminação bacteriana dos dentes poderia funcionar como reservatório de recolonização da superfície dental, dessa maneira podendo contribuir para alguns dos insucessos da terapêutica periodontal.

Para avaliar se saúde periodontal pode ser obtida sem a remoção do cemento doente em humanos, NYMAN et al. ${ }^{46}$ no mesmo ano obtendo acesso cirúrgico às superfícies radiculares, removeram a totalidade do cemento de dentes acometidos por doença periodontal em um grupo, enquanto em outro grupo realizaram polimento da superfície radicular, para então eliminar o cálculo cuidadosamente com a precaução de não remover cemento. Os achados neste estudo "in vivo" mostraram que o simples polimento da superfície do cemento resultou em saúde periodontal, sugerindo que as endotoxinas presentes no interior do cemento ou são neutralizadas pela resposta inflamatória do hospedeiro, ou esses produtos bacterianos citotóxicos estão localizados tão superficialmente no cemento que são removidos pelo simples procedimento de polimento. Consideraram que embora esses resultados não devam ser interpretados no sentido de que a remoção do cemento na terapia periodontal seja evitada, pois eliminação do cálculo não pode ser feita sem remoção mínima do cemento, a remoção 
intencional excessiva de cemento com o propósito de eliminar endotoxinas parece não ser justificada. Salienta-se, entretanto, que os autores aceitaram a formação de epitélio juncional longo, conforme resultado de trabalho anterior em cães (NYMAN et al., 1986) ${ }^{45}$, porém os pacientes receberam controle profissional a cada duas semanas durante período de 3 meses de experimento.

Relativamente à distribuição e quantificação de endotoxinas na estrutura do cemento, HUGHES; SMALES ${ }^{29}$ em 1990, usaram 12 dentes extraídos por periodontite, identificando as concentrações de LPS por impregnação com prata e micro-análise a raios $X$ em áreas livres de placa ou cálculo. As maiores concentrações situaram-se nas regiões mais apicais da bolsa periodontal, porém ainda assim foram em quantidades pequena e localização muito superficial, sugerindo que o significado clínico da LPS associada ao cemento, tem sido superestimado. Foi interessante o fato dos autores terem considerado a demonstração de LPS como fator indicador mais importante da presença de bactérias retidas e cálculo, do que LPS ligada ao cemento em si.

Em 2001, BABAY ${ }^{05}$ analisou a adesão de fibroblastos de gengiva humana a superfícies radiculares com doença periodontal e tratadas por raspagem e/ou tratamento químico. Os dentes selecionados tiveram meia face tratada mecanicamente de modo a formar 3 grupos iniciais: um raspado com cureta Gracey 7/8, outro com raspador ultra-sônico piezo-elétrico SEM e o 3ํㅡㄹ raspador ultra-sônico piezo-elétrico Amdent. Obtiveram fragmentos contendo metade da raiz instrumentada e metade não instrumentada que serviu como controle. Os fragmentos raspados foram redivididos em quatro grupos, que receberam por 3 minutos, os seguintes tratamentos: solução salina; ácido cítrico; tetraciclina hidroclorídrica ( $\mathrm{pH} 1.8$ ) e EDTA a $8 \%$ dissolvido em solução salina, fosfato tamponada $(\mathrm{pH}$ 7.3). Todos os espécimes foram plaqueados, recobertos com MEM contendo fibroblastos gengivais humanos, incubados por 72 horas e processados para MEV. Concluiu que os fibroblastos não aderiram em dentes com doença periodontal não tratados; apresentaram-se em pequeno número sobre superfícies somente raspadas e foram abundantes nas raízes condicionadas, sem 
diferença entre os agentes utilizados. Além disso, notaram que as células aderiram mais sobre superfícies ultra-estruturalmente rugosas do que lisas.

Preocupada com a receptividade biológica da superfície radicular à adesão de fibroblastos periodontais de seres humanos, SANT'ANA ${ }^{56}$ (2001) desenvolveu experimento de tratamento de raízes periodontalmente envolvidas por raspagem com e sem condicionamento por gel de ácido cítrico em mistura com tetraciclina para, então, proceder à aplicação de PDGF, TGF e IGF, isolados e em associação. Os fibroblastos do ligamento periodontal foram obtidos de dentes humanos não contaminados e cultivados em MEM adequado para possibilitar a obtenção de uma suspensão de células contendo $10^{3}$ fibroblastos, tendo sido usados fibroblastos de $5^{\mathrm{a}}$ geração. Os padrões tratados foram colocados em placas de Petri e cobertos pela suspensão de $10^{3}$ células , sendo então imersos em MEM, onde permaneceram por $24 \mathrm{~h}$ em câmara de gás carbônico a $5 \%$ e ar a $95 \%$, após o que foi feita a fixação em glutaraldeído, seguindo-se a análise em MEV. Os resultados mostraram que o condicionamento por ácido produziu aumento da adesão e proliferação de fibroblastos sobre as raízes, que se manifestou em maior quantidade em ordem decrescente nos padrões tratados pela associação dos fatores de crescimento, PDGF, TGF e IGF, todos significativamente diferentes dos controles, nos quais não se aplicou nenhuma das formulações dos fatores de crescimento. Esses resultados mostraram a importância do tratamento adequado da superfície radicular no estabelecimento da biocompatibilidade necessária à obtenção de regeneração periodontal, ilustrando, uma vez mais, a importância de que é revestido o tratamento adequado da raiz.

\subsection{Efeitos da Instrumentação sobre a Superfície Radicular}

Para responder à questão: "o US é mais eficiente do que a cureta em remover cálculo?”, em 1961 STENDE; SCHAFFER ${ }^{61}$ realizaram trabalho de raspagem no total de 150 dentes condenados por razão protéticas, e agrupados de acordo com os seguintes instrumentos usados: curetas McCall; curetas Gracey; ponta de US regular e ponta de US similar à cureta McCall. 
Os autores concluíram que o US não deixa a superfície radicular plana, o que só pode ser alcançado por instrumentação manual, apesar de ambos os instrumentos deixarem a superfície com quantidades de cálculo semelhantes. Todavia afirmaram que o US deve ser considerado auxiliar e não substituto da instrumentação manual.

Por sua vez, BJORN; LINDHE08, em 1962, procuraram desenvolver um método para determinar mais objetivamente o efeito dos procedimentos de raspagem radicular, por meio de pressão aplicada sobre a superfície radicular durante a raspagem. Comparando o efeito da instrumentação ultrasônica e por raspadores convencionais, observaram que a raspagem com US, usando pressão de mais de 50-100g., transforma a superfície inicialmente lisa em áspera, aumentando o grau de aspereza com o aumento da pressão. Com raspadores convencionais foram produzidos fragmentos descontínuos da dentina tratada.

Em 1964, MOSKOW; BRESSMAN ${ }^{41}$ estudaram clínica e histologicamente o efeito da instrumentação manual e ultra-sônica na superfície do cemento, tendo observado que os dois métodos de instrumentação produziram a remoção efetiva de depósitos calcificados. Entretanto, embora a remoção grosseira do œmento tenha sido feita mais facilmente com as curetas manuais, o alisamento e remoção parcial do cemento de forma adequada foram obtidos mais eficientemente com os instrumentos ultra-sônicos. Além disso, defeitos em forma de buracos ou sulcos foram produzidos com os dois tipos de instrumentação, tendo se apresentado mais pronunciados quando usaram curetas manuais.

No mesmo ano, BELTING; SPJUT ${ }^{06}$ com o intuito de comparar os efeitos físicos de vários tipos de instrumentos (US utilizando potência média, rotatórios, vibratórios e curetas) na superfície radicular durante remoção de cálculo subgengival uitlizaram 103 dentes divididos em 4 grupos, que continham bolsa periodontal, os quais foram raspados por 30 ou 60 segundos, por um único operador. Após extração, as superfícies dentais foram avaliadas em seus 4 grupos macroscopicamente de modo cego. Isto posto, os dentes foram descalcificados e seccionados com o intuito de serem avaliados microscopicamente, para avaliação da profundidade de remoção da 
estrutura dental. Os resultados obtidos mostraram predominância da instrumentação manual quando se avaliou a lisura da superfície radicular, estando o US com superfície pontilhada. Com relação a perda de estrutura dental as curetas foram consistentemente menores quando comparados com os outros instrumentos. Os autores concluíram que os instrumentos oscilatórios e os de alta velocidade causaram mais danos à superfície radicular durante instrumentação subgengival do que as curetas.

Em 1968, CLARK et al. ${ }^{14}$, investigaram a influência da força e potência aplicada na remoção de estrutura radicular com o uso do US. Os defeitos produzidos em termos de volume e a média da estrutura dental removida foram medidas por meio de perfilômetro. Os resultados demonstraram que a utilização do instrumento ultra-sônico em potência média se comparado com alta potência e com baixa força de aplicação (75 g quando comparado com forças de $125 \mathrm{~g}$. e 175g.), resultaram em perda mínima de volume e profundidade da estrutura radicular removida.

Com o objetivo de verificar ultraestruturalmente por MEV superfícies tratadas por instrumentação manual e US, JONES et al. ${ }^{32}$, em 1972, instrumentaram 54 dentes, dos quais 28 apresentaram cálculo residual em regiões consideradas lisas à inspeção clínica com explorador. Se bem que os dois tipos de instrumentação não tenham mostrado diferenças entre si na remoção de cálculo, nas áreas em que o cálculo foi removido o instrumento ultra-sônico causou dano mínimo à superfície radicular, enquanto as auretas manuais usualmente impregnaram ou removeram partes do cemento, dentina ou esmalte.

Usando MEV, PAMEIJER et al. ${ }^{48}$, em 1972, avaliaram superfícies radiculares após instrumentação manual (curetas Gracey) e ultra-sônica (Cavitron com pontas P10) "in vivo" e "in vitro". No protocolo "in vivo" usaram 25 dentes com extração indicada por razões protéticas e naquele "in vitro" usaram 30 dentes recém extraídos. Em cada estudo, um grupo de 10 dentes foi tratado com curetas manuais e outro com instrumentos ultra-sônicos. Os cinco dentes remanescentes do estudo "in vivo" serviram como controle. Os últimos 10 dentes do estudo "in vitro" foram desgastados de forma achatada até a dentina e polidos para ficarem lisos. Um terço dessa superfície tratada 
com instrumentos manuais, um terço com instrumentos ultra-sônicos e um terço sem tratamento serviram como controle. A análise comparada dos resultados mostrou, em ambos os estudos, que o ultra-som deixou a superfície radicular limpa e praticamente inalterada, enquanto os instrumentos manuais removeram mais estrutura dental e foram efetivos em aplainar as superfícies radiculares. Entretanto, na dentina exposta polida, a instrumentação manual, além de remover estrutura dental, deixou a superfície áspera em relação àquela brunida pelo instrumento ultra-sônico.

É interessante observar a ponderação de WILKINSON; MAYBURY $(1973)^{64}$ de que a rugosidade da superfície do dente, causada tanto pela doença periodontal como pela instrumentação radicular, pode facilitar o acúmulo de placa bacteriana e cálculo e, portanto, a remoção de substâncias tóxicas acumuladas e a preparação da superfície radicular pelo aplainamento são geralmente procedimentos importantes no tratamento e prevenção da DP. Com essa preocupação os autores avaliaram em MEV a superfície radicular após o uso de diferentes instrumentos periodontais em dentes humanos e observaram que as curetas produziram superfícies radiculares mais lisas e planas. O US produziu superfícies radiculares caracterizadas por depressões e irregularidades consideradas não desejáveis, por facilitarem o acúmulo de placa.

Em 1974, ROSENBERG; ASH JR. ${ }^{55}$ determinaram a relação entre a rugosidade da superfície radicular, o acúmulo de placa e o índice de inflamação dos tecidos gengivais em seres humanos. Foram raspados e aplainados, até a textura de superfície vítrea, dentes com DP de moderada a severa, utilizando curetas novas, Cavitron e grupo controle. Após instrumentação radicular, os dentes foram extraídos nos períodos pósoperatórios de 28 a 232 dias para verificar o efeito da rugosidade radicular no acúmulo de placa e inflamação gengival. Os resultados demonstraram que embora existissem diferenças estatisticamente significantes nas médias de valores de rugosidade (curetas-9.51; US-17.21 e controle-18.30) encontrados nas superfícies radiculares, não foram encontradas diferenças significativas no acúmulo de placa (cureta-48.55; US-45.66 e controle-52.72) e inflamação gengival (cureta-3.11; US-2.88 e controle-2.77). Uma explicação seria que as 
diferenças de rugosidade foram estatisticamente significativas mas não o suficiente para serem de significância biológica. A explicação mais plausível foi associada à pobre higiene bucal dos pacientes nesta pesquisa, tornando impossível avaliar a capacidade de uma superfície lisa de melhorar o controle da placa. Portanto, consideraram que a eliminação do cálculo instalado dentro de irregularidades da raiz deve ser considerada a principal justificativa para 0 aplainamento radicular.

WOODRUFF et al. ${ }^{66}$, em 1975 compararam a eficácia dos instrumentos ultra-sônicos Orbison $®$ e Cavitron $®$, classificando as superfícies instrumentadas em lisas ou rugosas através de avaliação em MEV. Após serem extraídos, os 20 dentes usados no experimento foram divididos aleatoriamente em terços. Um terço foi instrumentado pelo Cavitron ${ }^{\circ}$, o terço médio serviu como controle e no outro terço foi utilizado o Orbison $®$, sempre com angulação de 15 graus e realizada pelo mesmo operador durante 2 minutos. Das 20 superfícies instrumentadas, cada instrumento produziu 17 consideradas lisas e 3 rugosas. As superfícies controle estavam cobertas por placa bacteriana e fibras do ligamento periodontal. Os autores concluíram que os dois instrumentos foram efetivos na remoção de placa e cálculo, não havendo diferença no desempenho de ambos. Além disso produziram graus semelhantes de lisura superficial.

VAN VOLKINBURG et al. ${ }^{63}$, em 1976, realizaram estudo para comparar a textura da superfície radicular obtida após uso de curetas, US (Cavitron) e instrumento sônico (Alpha sonic). A rugosidade da superfície radicular foi avaliada com perfilômetro e MEV. Utilizaram 32 dentes humanos,cujas faces mesiais e distais foram tratadas por um único instrumento ou por combinação deles, formando 7 grupos. Todos os grupos foram raspados até que se obtivesse lisura superficial mediante avaliação com sonda exploradora. Delimitaram a área a ser raspada com lápis, apical à JEC, de modo a formar um retângulo de $5 \times 7 \mathrm{~mm}$. As amostras foram primeiro avaliadas no perfilômetro, após o que 47 das 64 amostras iniciais raspadas foram preparadas para análise em MEV com aumentos de 120X e 600X. Após avaliação com os referidos aparelhos, realizaram secções nas raízes tratadas para determinar se a superfície radicular instrumentada consistia de 
cemento e/ou dentina. Os resultados com relação ao perfilômetro identificaram dois grupos de resultados, um com superfícies menos rugosas e outro com mais rugosas. O primeiro composto pelos seguintes grupos de tratamento: grupos 1- Alpha sonic + cureta; 2 - cureta somente; 3- Cavitron + cureta; e 4- cureta + Cavitron. As superfícies mais rugosas foram obtidas com os seguintes instrumentos: 1 Cavitron somente; 2- cureta + Alpha sonic; e 3- Alpha sonic somente. Com relação a MEV os resultados mostraram ser semelhantes ao perfilômetro e as superfícies mais irregulares foram produzidas pelo Cavitron e Alpha sonic. $\mathrm{O}$ exame histológico voltado à remoção de cemento mostrou que os grupos tratados com curetas somente, ou associados a outros instrumentos, provocaram maior perda de substância da superfície radicular, sendo o Cavitron e Alpha sonic os que apresentaram maior índice de cemento remanescente. Entretanto, a instrumentação manual com curetas produziu maior lisura da raiz do que Cavitron e Alpha sonic, não havendo diferença de capacidade entre Cavitron e Alpha sonic em promover lisura superficial..

Com o objetivo de avaliar a rugosidade da superfície radicular após instrumentação, MEYER; LIE ${ }^{40}$, em 1977, utilizaram a combinação de métodos de mensuração da microrugosidade com rugosímetro e MEV. As rugosidades das superfícies radiculares foram avaliadas após remoção do cálculo pelos seguintes instrumentos: curetas Gracey, instrumentos Roto-Pro; pontas diamantadas (DW2 Viking) e Ultra-som (Cavitron-ponta p10). Para mensurar a microrugosidade foi usado rugosímetro, utlizando índice de microrugosidade (MRI). Neste caso os resultados demonstraram que as curetas produziram menos rugosidade que os outros instrumentos, sendo que - US e as pontas diamantadas deixaram a superfície irregular. Após avaliação pelo rugosímetro, os espécimes foram preparados para análise em MEV, com aumento de $12 \mathrm{X}$ a $150 \mathrm{X}$. O valor médio para cada instrumento constituíram o índice de rugosidade (SRI). Considerável quantidade de cálculo remanescente, assim como a presença de irregularidades foram encontradas nos espécimes instrumentados com US. As curetas proporcionaram superfícies mais regulares. 
Também preocupados com a propriedade de tratamento adequado das raízes, no mesmo ano LIE; MEYER ${ }^{37}$ estudaram a eficiência da remoção de cálculo e quantidade de perda de substância radicular resultante do uso de curetas manuais, ultra-som, ponta rotatória diamantada e instrumento Rot-pro examinados através de MEV. Superfícies radiculares de incisivos inferiores colocados em modelos foram limpos de depósitos aderidos e fotografados em MEV a um aumento padrão de $72 \mathrm{X}$ e avaliados. Escores foram dados para cálculo remanescente $(\mathrm{RCl})$ e perda de substância radicular (LTSI) de acordo com critérios estabelecidos. Foram examinadas oito áreas das superfícies radiculares instrumentadas. Os resultados revelaram que a remoção de cálculo foi mais efetiva após instrumentação com ponta diamantada ( $\mathrm{RCH}$ 0.4). Cureta ( $\mathrm{RCH} 1.4)$ e Roto-pro ( $\mathrm{RCH} 1.9)$ removeram cálculo quase que proporcionalmente, enquanto US (RC+2.6) foi o instrumento menos satisfatório na remoção de cálculo da superfície radicular. Com relação à quantidade de remoção de substância radicular os instrumentos Roto-pro (LTSH1.3), curetas (LTSH1.3) e US (LTSH1.4) removeram quantidades semelhantes de estrutura radicular, embora a textura das superfícies estivessem diferentes, enquanto as pontas diamantadas (LTSF2.8) removeram todo o cemento, além de deixar marcas profundas da instrumentação na dentina. Os autores levantaram a preocupação quanto ao fato do clínico considerar a remoção excessiva de substância radicular como biologicamente aceitável, desde que como meio necessário para completa remoção de cálculo dental com objetivo de criar superfície radicular lisa. Para esse fim, o presente estudo tem revelado notável diferença entre os instrumentos utilizados.

Por meio de revisão da literatura, GARRET ${ }^{24}$ em 1977, foi em busca de respostas relacionadas às perspectivas do aplainamento radicular como meio de proporcionar superfícies radiculares livres das mudanças patológicas ocorridas subseqüente à doença periodontal. As mudanças que ocorrem nas superfícies radiculares expostas ao meio ambiente da bolsa periodontal, cuja exposição torna-a citotóxica ao epitélio e fibroblastos quando localizados em cultura de tecidos, a qual o aplainamento radicular torna-se necessário com o intuito de remover substâncias patológicas que estão aderidas à superfície 
radicular e com isto criar meios mais favoráveis aos tecidos adjacentes. Isso posto, torna-se especialmente significante porque várias dessas células são responsáveis em promover nova inserção em áreas previamente expostas à doença periodontal. Outro ponto importante, está relacionado com lisura da superfície, a qual é o único critério do ponto de vista clínico a ser avaliado e que indica se cálculo subgengival foi removido ou não, porém, quando analisado em MEV revelam a presença de cálculo residual. No entanto, o autor ressalta que há poucas evidências biológicas na qual a lisura da superfície radicular pode diminuir o crescimento bacteriano ou facilitar a sua remoção. A remoção dos contaminantes e a remoção da zona hipermineralizada (alteração do cemento exposto relacionado com sua fase mineral) da superfície radicular via aplainamento radicular, é pré-requisito no intuito de ganhar novo tecido de inserção em áreas previamente afetadas e também tornar mais efetiva a desmineralização, o que demonstra a eficácia do aplainamento radicular em preparar a superfície radicular adequadamente para a desmineralização e subsequentemente nova inserção. Ainda nesse artigo é discutido qual instrumento (cureta ou US) é mais efetivo em remover placa, cálculo e cemento contaminado da raiz e dentro dos limites deste estudo, a cureta demonstra superioridade em remover cemento exposto e por essa razão é parte necessária ao procedimento de aplainamento radicular. A conclusão que se chega é que a partir de dados da literatura corrente, a instrumentação manual continua sendo parte importante na raspagem e aplainamento radicular pela sua habilidade em remover cemento exposto quando comparado ao ultra-som e o mesmo com sua habilidade em remover cálculo dental mais rápido e trazendo conforto ao paciente, parece ser bem melhor a combinação dos dois tipos de instrumentação. Adicionalmente, meticulosos estudos controlados determinam a quantidade de estrutura dental removida por ambas técnicas de instrumentação, bem como a quantidade necessária a ser removida para alcançar superfície radicular saudável.

RABBANI et al. $(1981)^{52}$ realizaram estudo apresentando avaliação da efetividade da raspagem e aplainamento radicular relacionada à profundidade de bolsa e tipos de dentes, com a finalidade de determinar se 
existe alguma correlação entre cálculo remanescente e profundidade de bolsa e se o tipo de dente, anterior ou posterior, influencia a quantidade do cálculo remanescente. Os resultados demonstraram grande correlação entre porcentagem de cálculo residual e profundidade de bolsas encontradas, evidenciando que quanto maior a profundidade de bolsa mais difícil foi a instrumentação. Os tipos de dentes não influenciaram os resultados.

Por sua vez, HUNTER et al. $^{30}$, em 1984, compararam a instrumentação manual e ultra-sônica, "in vivo", por meio de acesso cirúrgico em seres humanos. Os dentes estudados apresentavam no mínimo $5 \mathrm{~mm}$ de perda de inserção e grau dois ou três no índice de cálculo dentário de Ramfjord. Feito o acesso cirúrgico, os dentes foram instrumentados até à obtenção de estrutura dura e lisa mediante avaliação por um explorador de ponta fina. Os espécimes foram analisados estereomicroscopicamente e histologicamente por microscopia óptica. Com relação a estereomicroscopia (feita em 25 dentes para cada grupo), as quantidades de cálculo residual foram favoráveis aos instrumentos manuais $(5,78 \%$ de cálculo residual) em comparação com os ultra-sônicos $(6,71 \%$ de cálculo residual). Com relação aos resultados histológicos (obtidos do processamento histológico de 20 dentes para cada grupo), foram encontrados cálculos residuais em doze espécimes instrumentados manualmente contra apenas quatro espécimes nos quais se usou o ultra-som. A diferença entre os resultados estereoscópicos e histológicos foi reputada ao fato de que o uso de vibração ultra-sônica possa ter deixado o cálculo solto, sendo então removido durante o processamento histológico. Avaliando a qualidade da superfície raspada, os autores observaram que os instrumentos manuais produziram porcentagem de $56,6 \%$ de áreas consideradas lisas contra $18,8 \%$ conseguidas com os instrumentos ultra-sônicos. Os autores aventaram a possibilidade de que 0 cálculo residual é a razão pela súbita recorrência de bolsas profundas.

Em 1986, BYE; GHILZON; CAFFESSE ${ }^{11}$ realizaram estudo "in vitro" com dentes extraídos e "in vivo" em dentes a serem extraídos , para analisar a rugosidade superficial resultante da raspagem e polimento radicular com curetas e US. No estudo "in vitro" foram utilizados 30 dentes humanos recém extraídos, que foram instrumentados da seguinte forma: 10 dentes raspados 
com curetas Columbia ำ 13/14; 10 dentes raspados com pontas de US Piezomatic P2 e 10 com pontas de US Cavitron. Todos os dentes foram raspados até que o operador obtivesse lisura superficial à análise com sonda exploradora ํo 17 . Outros 10 dentes foram deixados sem instrumentação e serviram como controle. Após instrumentados, os dentes foram analisados com Perfilômetro. Os resultados levaram os autores a considerar que a instrumentação manual e a ultra-sônica com aparelho Piezomatic P2 produziram diminuição significativa da rugosidade superficial em relação ao controle, porém a raspagem manual conduziu à obtenção de superfícies radiculares significativamente mais lisas do que aquela com ultra-som Piezomatic P2; as superfícies radiculares dos dentes posteriores apresentaram-se mais rugosas do que a dos anteriores, a despeito de qualquer tipo de instrumentação usado.

Com o intuito de estudar em MEV os efeitos causados na superfície radicular por meio do uso de curetas e aparelho ultra-sônico, BENFENATTI et al. ${ }^{07}$, em 1987, utilizaram 4 tipos de instrumentação: curetas afiadas, curetas sem corte, curetas com arestas de corte danificadas e ultra-som. Os dentes foram instrumentados por um único operador até que a superfície radicular estivesse lisa e dura ao exame com sonda exploradora. Ao todo foram utilizados 30 dentes, perfazendo o total de 6 dentes para cada grupo, sendo 4 instrumentados e 2 instrumentados e depois polidos com pedra pomes. Os autores concluíram que as curetas afiadas foram mais eficientes na remoção do cálculo e quando seguida de polimento produziram superfície lisa e bastante regular. As curetas sem corte proporcionaram superfície bastante lisa, atribuída ao fato de que tais instrumentos espalharam alguns resíduos sobre a superfície, produzindo "smear layer". As curetas danificadas, além da camada de resíduos, produziram superfície com riscos e ondulações, causadas pelas irregularidades de suas lâminas, enquanto as superfícies tratadas pelo US foram marcadas por inúmeras saliências, rugosidade e com textura irregular e nodular. O polimento mostrourse efetivo em melhorar a lisura superficial das raízes de modo geral. Em função dos resultados e aspectos discutidos os autores consideraram que a cureta afiada 
mostrou ser o meio mais proficiente na remoção de cálculo e no alcance de aceitável superfície radicular lisa.

CHECCHI; PELLICCIONI ${ }^{13}$, em 1988, em estudo "in vitro" também compararam as instrumentações manual e ultra-sônica (Cavitron) quanto à sua efetividade na remoção de endotoxinas de superfícies radiculares. Dentes comprometidos por DP avançada foram extraídos e tiveram suas superfícies radiculares divididas ao meio. Uma parte foi submetida à instrumentação com curetas e a outra parte instrumentada com US, ambas até a obtenção de superfície radicular lisa. Após a instrumentação, os espécimes foram lavados e esterilizados em autoclave. Dentes com saúde periodontal foram usados como controle, enquanto dentes com envolvimento periodontal sem tratamento serviram como controle negativo. Não foram observadas nenhuma diferença significativa no crescimento de fibroblastos, nos fragmentos de superfícies radiculares tratados tanto com curetas como pelo US, da mesma maneira que, após período de incubação de 24 horas haviam fibroblastos aderidos por toda as superfícies radiculares instrumentadas, seja por meio de curetas ou por US. Embora tenham empregado calor de autoclave para promover a esterilização dos fragmentos, também submeteram os fragmentos não tratados ao mesmo procedimento e verificaram menor crescimento de fibroblastos nesses fragmentos.

Com o objetivo de avaliar o efeito desintoxicante da instrumentação ultra-sônica, SMART et al. ${ }^{60}$, em 1990, verificaram, por meio do método Limulus amoebocyte lysate, a quantidade de toxinas residuais (LPS) encontrada em superfícies radiculares tratadas. Foram utilizados 20 dentes, extraídos por doença periodontal, sem presença de cálculo clinicamente detectável. As superfícies foram instrumentadas com US Cavitron 2002 ponta TF-10, com angulação de 15 graus, sob potência média e fluxo de água refrigerada, até que estivesse lisa. Os níveis de substâncias lipopolissacarídicas (LPS) residuais encontrados em 19 das 20 superfícies tratadas foram comparáveis aos encontrados em dentes extraídos com saúde periodontal (10 terceiros molares inclusos). Diante desses resultados, os autores concluíram que a instrumentação ultra-sônica foi efetiva na remoção de LPS e possivelmente de outras substâncias citotóxicas das superfícies de 
dentes envolvidos por doença periodontal. Entretanto, chama a atenção o fato dos autores terem usado dentes periodontalmente envolvidos, porém, curiosamente não apresentavam cálculo, ficando a dúvida quanto à contaminação desses dentes, uma vez que dentes nas mesmas condições e sem tratamento não foram utilizados no experimento. De qualquer maneira, deixaram implícito o questionamento quanto à necessidade de se aplainar as raízes em vez de simplesmente realizar raspagem superficial.

Nesse mister, em 1990 COLDIRON et al. ${ }^{16}$ publicaram resultados de estudo "in vitro", realizado com o objetivo de quantificar o cemento removido durante a instrumentação manual com curetas Gracey 11/12. Usaram 92 dentes sadios e realizaram de 20 a 70 golpes instrumentais com pressão média de $982 \mathrm{~g}$. As curetas foram afiadas a cada 10 a 15 golpes. Analisando valores médios mostraram que a remoção completa de cemento geralmente é alcançada com 20 golpes de cureta, embora fragmentos de cemento tenham permanecido em várias secções mesmo no grupo de 70 golpes. Todavia, houve tendência de diminuir a freqüência de cemento remanescente com o aumento do número de golpes na superfície radicular, a ponto de observarem que a profundidade média da maioria dos defeitos radiculares alcançados com os procedimentos estandardizados usados neste estudo somente atinge a extensão de penetração bacteriana proposta quando 50 ou mais golpes são empregados por sítio. Ainda neste estudo os autores previram tempo de 90 minutos por quadrante para raspagem eficiente. Esse estudo revelou a inconsistência da terapia mecânica empregada, aumentando a significância do tratamento químico ou desintoxicaçãp no alcance de resposta de cura mais previsível no tratamento da doença periodontal, mesmo porque os autores enfatizaram que o emprego de terapia mecânica única leva preferentemente à formação de epitélio juncional longo mais do que de nova inserção de tecido conjuntivo. Finalmente estressaram que aplainamento radicular mais extenso (maior número de golpes por sítio) e maior afiação dos instrumentos do que tem sido correntemente usados na terapia periodontal são necessários para alcançar os objetivos clínicos de aplainamento radicular. 
Por sua vez, em 1990 KEPIC et al. ${ }^{34}$ propuseram 2 sessões de raspagem e aplainamento radicular, sendo uma em campo fechado e outra em campo aberto, com o intuito de promover a total remoção de cálculo em dentes com doença periodontal severa. Para tanto, em campo fechado trataram 14 dentes com US e outros 17 com curetas. Após período de cicatrização de 4 a 8 semanas, os dentes dos referidos grupos receberam o mesmo tipo de tratamento em campo aberto (cirurgia). Os dentes foram extraídos e examinados em microscopia óptica e MEV. Os resultados demonstraram que 12 dos 14 dentes tratados com US e 12 dos 17 tratados com curetas apresentavam cálculo remanescente analisados com MO. Os autores concluíram que a completa remoção do cálculo da superfície radicular contaminada por doença periodontal é objetivo difícil de ser alcançado.

No sentido de avaliar a detecção clínica de cálculo residual após instrumentação subgengival e compará-la à presença de cálculo identificado por estereomicroscopia em dentes extraído, SHERMAN et al. ${ }^{59}$ em 1990, utilizaram 476 superfícies radiculares obtidas de 101 dentes e instrumentadas com US (ponta P10) e curetas Gracey, sem fazer restrições quanto ao tempo gasto na instrumentação. Ao final do terceiro mês os dentes foram extraídos e avaliados em estereomicroscópio com aumento de 10 vezes, para identificar a presença ou ausência de cálculo. Os resultados demonstraram que $57 \%$ de todas as superfícies analisadas apresentaram cálculo residual, enquanto ao exame clínico somente $18,8 \%$ dessas superfícies foram associadas com a presença de cálculo. Esse estudo indicou as dificuldades em se determinar clinicamente a eficácia da instrumentação subgengival e mostrou que a remoção completa do cálculo da superfície radicular periodontalmente doente é rara.

Em estudo "in vitro" de 1991, ZAPPA et al..$^{69}$ avaliaram a quantidade de substância radicular removida pela raspagem e aplainamento radicular, usando número de golpes instrumentais definido, mediante a aplicação de forças conhecidas. Em uma área padronizada da raiz foram aplicados 40 golpes de trabalho com curetas Gracey 1/2, usando pequena força em 30 dentes e forças maiores em 10 dentes. A perda de substância radicular acumulada foi mensurada após 5, 10, 20 e 40 golpes. Adicionalmente, foi 
calculada a perda por golpe de trabalho para os grupos de 0 a 5, 6 a 10, 11 a 20 e 21 a 40 golpes. Os resultados mostraram que a força média por golpe aumentou ligeiramente até os 40 golpes, enquanto a remoção de substância radicular por golpes diminuiu. A remoção de substância durante os golpes de 1 a 5 foi de 6,8 ìm usando-se forças pequenas e 20,6 ìm usando-se forças maiores, ao passo que de 21 para 40 golpes a remoção média por golpe foi de 2,3 ìm com pequenas forças e 5,6 ìm com forças maiores. Estes resultados sugeriram que a instrumentação radicular com aplicação de grandes forças remove mais substância radicular e que esta remoção tornase menor com o aumento do número de golpes de trabalho. Com esses resultados os autores chamaram a atenção para o risco de que a instrumentação freqüente da superfície radicular pode por em risco a integridade pulpar.

A efetividade de diferentes métodos de instrumentação da superfície radicular foi comparada por ESCHLER; RAPLEY20, em 1991, por mensuração da quantidade de depósitos residuais observados após o tratamento de 90 dentes com envolvimento periodontal. Os dentes extraídos foram aleatoriamente distribuídos em 8 grupos experimentais e um controle não tratado, esquematizando-se o grupo de acordo com os seguintes meios terapêuticos usados individualmente ou em combinação: cureta Columbia 13/14; instrumento ultra-sônico com ponta P10 em potência máxima; instrumento ultra-sônico com ponta diamantada P10 em potência máxima e tratamento químico com antifórmio por 5 minutos seguido de imersão em ácido cítrico por 30 segundos). Dentro deste protocolo, incluiu um grupo no qual o tratamento foi feito com ponta ultra-sônica diamantada P10 em alta potência, seguido por tratamento com solução de antiformina por 5 minutos, imersão em solução de ácido cítrico a $5 \%$ por 30 segundos, lavagem por 1 minuto, e, finalmente raspagem com cureta Columbia 13/14 afiada, até a obtenção de superfície lisa à sensibilidade tátil. Os espécimes foram analisados por meio de estereomicroscopia, sistema analisador de imagens (ZIDAS) e microscopia óptica. Em relação aos depósitos residuais os autores concluíram que os grupos de instrumentação mecânica deixaram quantidade significantemente menor de depósitos nas superfícies do que o tratado 
quimicamente e o controle. Embora os autores mencionassem a identificação de cemento em todos os espécimes, na porção mais coronal das secções de 4 espécimes observaram a remoção completa do cemento para o grupo que usou a combinação de ponta ultra-sônica diamantada P10, cureta e antiformina/ ácido cítrico, o grupo no qual a transição da dentina para o cemento se deu com superfície de transição biselada lisa. Consideraram que sob condições de acesso não limitado, todos os métodos mecânicos de instrumentação radicular atuam essencialmente de maneira similar.

No ano seguinte DRAGOO ${ }^{19}$ avaliou os efeitos da raspagem de superfícies subgengivais realizadas por 3 tipos de instrumentação: manual, ultra-sônica com ponta P 10 do Cavitron, ultra-sônica com ponta P10 modificada (menor espessura). Após a instrumentação, os dentes foram extraídos, possibilitando o exame de 168 superfícies com relação à placa e cálculo residuais, rugosidade superficial e níveis de inserção. Estas superfícies consistiram de 76 tratadas com instrumentação manual, 74 por ultra-som com ponta modificada e 18 por ultra-som com ponta não modificada. Todas as superfícies tratadas foram classificadas de acordo com uma escala de 0 a 5, na qual o grau 0 foi atribuído aquela com maior lisura, enquanto que superfícies com irregularidades mais visíveis receberam o grau 5. A média atribuída às superfícies tratadas pelo instrumento ultra-sônico com ponta não modificada foi de 4,3, denotando a presença de irregularidades maiores, seguidas das superfícies tratadas por instrumentação manual $(3,4)$ e das tratadas pelo ultra-som com ponta modificada $(1,4)$, que produziu, portanto, maior lisura superficial. Além disso, foram verificados menores índices de cálculo residual quando da utilização do instrumento ultra-sônico com ponta modificada.

Com o objetivo de verificar a influência da rugosidade produzida pela instrumentação na formação da placa subgengival, LEKNES et al. $^{38}$, em 1994, realizaram estudo em cães, comparando os resultados do tratamento mecânico por raspagem manual com curetas afiadas e daquele com pontas diamantadas em evoluções de 20000 a 30000 rpm, em 10 bolsas periodontais criadas nos caninos maxilares e 10 nos mandibulares de cães. Após alimentação com dieta formadora de placa durante 70 dias, os 
espécimes foram obtidos e preparados para estereomicroscopia e MEV. Os autores observaram que nas superfícies tratadas com curetas houve menor produção de riscos e ranhuras; também verificaram que, em todos os níveis dentais estudados (cervical, médio e apical), as superfícies instrumentadas com pontas diamantadas possibilitaram maior acúmulo de placa subgengival (76\%) do que as tratadas por meio de curetas. Portanto, o presente estudo demonstrou que a rugosidade deixada pela instrumentação subgengival influenciou significativamente a colonização microbiana subgengival.

Estudo "in vitro" com o intuito de avaliar a textura da superfície radicular após raspagem com instrumentos manuais, raspadores ultrasônicos e raspador sônico foi desenvolvido por JACOBSON et al. ${ }^{31}$ (1994), fundamentado em análise por MEV. O material experimental consistiu de 48 dentes humanos extraídos por razões ortodônticas e divididos aleatoriamente em 6 grupos: grupo 1 - superfícies tratadas com curetas McCall 13/14 novas, com angulação de $80-85^{\circ}$ e pressão de $500 \mathrm{~Pa}$, aplicando 10 golpes de raspagem; grupo 2 - superfícies tratadas com curetas igualmente ao grupo anterior, reafiadas pelo método de McBinn e tratadas com 10 golpes de raspagem; grupos 3 e 4 - superfície tratada com 10 movimentos de um lado para outro (sentidos longitudinal e transversal) com ponta $\mathrm{n}$ 은 33 (grupo 3) e $\mathrm{n}^{\circ}$ 34 (grupo 4) de aparelho ultra-sônico piezo elétrico (Amdent AB), trabalhando sem desviar o cabo do instrumento mais do que $10^{\circ}$ em relação ao longo eixo de dente, sem exceder a pressão de $50 \mathrm{~Pa}$ e usando potência média; grupo 5- superfícies tratadas com 10 movimentos iguais aos grupos 3 e 4, porém com raspador eletromagnético (Cavimed 2000), usando pressão não superior a $50 \mathrm{~Pa}$ com potencia média e; grupo 6 superfícies tratadas com 10 movimentos duplos aplicados com ponta universal de aparelho sônico (Titan S) sobre a superfície radicular da mesma maneira que nos grupos 3 e 4, sob pressão não superior a $50 \mathrm{~Pa}$ e pressão de ar de 3bar. Os dentes foram divididos ao meio tendo metade da superfície instrumentada e outra metade não instrumentada como controle. As amostras analisadas, instrumentadas ou não, foram demarcadas transversalmente com um sulco na porção apical e outro na coronal da raiz, perfazendo distância variável de 6 a 10mm. Os autores verificaram que o grupo controle tinha aparência de mosaico e que a 
superfície do cemento na porção mais coronária apresentava aparência mais regular e uniforme do que na porção apical. Entre os grupos 1 e 2 (manual) evidenciou-se textura superficial similar independente da qualidade de corte do instrumento, sendo visíveis ranhuras e escavações paralelas ao longo eixo da raiz em aumento de 70X em MEV. Enquanto os instrumentos sônicos e manuais removeram maior quantidade de cemento, os instrumentos ultrasônicos produziram alterações na superfície radicular somente visíveis em aumento de 500X, o que possivelmente aconteceu, segundo os autores, pelas diferentes forças aplicadas durante a instrumentação.

Pouco tempo depois, considerando ainda não haver, à época, consenso sobre a obtenção das características desejadas da superfície radicular após a limpeza, SCHLAGETER et al. ${ }^{57}$ em 1996, avaliaram a lisura superficial resultante da instrumentação radicular por meio de acesso cirúrgico e processada com os seguintes instrumentos: curetas Gracey; US piezoelétrico; cureta motorizada ("Perioplaner"); raspador sônico e brocas diamantadas com espessura de 15 e75 ìm (Perioset com 20000 e 30000 rpm). As superfícies foram instrumentadas até que apresentassem lisura superficial avaliado clinicamente. A rugosidade superficial média e a profundidade média do perfil da rugosidade foram determinadas com aparelho planimétrico. Os autores concluíram que as curetas Gracey, curetas motorizadas e brocas diamantadas com granulação de15ìm produziram superfície mais lisa e menos rugosas do que as produzidas com instrumentos oscilatórios (curetas ultra-sônica e sônica e brocas diamantadas de granulação grossa).

Devido à incompleta remoção de cálculo durante a instrumentação radicular com curetas e ultra-som, YUKNA et al. ${ }^{67}$, em 1997, procuraram avaliar a efetividade na remoção de cálculo subgengival, de curetas manuais e três tipos diferentes de pontas de ultra-som (ponta comum, ponta diamantada de granulação fina e ponta diamantada de granulação média), usando como parâmetro a rugosidade superficial deixada pela raspagem radicular subgengival de 80 dentes com bolsas variáveis de 5 a $12 \mathrm{~mm}$ de profundidade. A instrumentação foi finalizada quando clinicamente a superfície se apresentava lisa à sensibilidade tátil com sonda exploradora. As 
áreas interessadas dos dentes extraídos foram analisadas em fotografias obtidas com aumento de 10X, as quais para tanto foram superpostas por tela de $4 \mathrm{~mm}$ e individualmente avaliadas com lentes de aumento, de forma cega, por dois examinadores, que não tinham conhecimento do tratamento realizado. As análises foram direcionadas para a profundidade de bolsa, cálculo remanescente e rugosidade superficial, para a qual foi respeitada uma escala de 1 a 4 na qual $1=$ superfície lisa; $2=$ pequenas irregularidades; $3=$ rugosidades moderadas; e $4=$ superfície rugosa. Foi ainda analisado o tempo necessário para que se obtivesse a lisura clínica da superfície radicular. Observaram que as três pontas de US foram mais rápidas que a cureta manual, porém sem variação entre elas. Quanto à rugosidade, os dentes raspados com curetas foram considerados mais lisos seguidos dos instrumentados com pontas ultra-sônicas diamantadas e dos instrumentos com pontas ultra-sônicas lisas. Quanto à efetividade da remoção de cálculo as pontas ultra-sônicas recobertas por diamante foram muito mais eficientes que as manuais e ultra-sônicas em bolsas com profundidade de moderada a profunda.

No ano seguinte, FLEMMIG et al. ${ }^{23}$ realizaram estudo para avaliar a influência da força lateral, angulação da raspagem, força aplicada pelo instrumento e tempo de instrumentação na remoção de substâncias radiculares, utilizando raspador ultra-sônico com ponta desenhada para raspagem subgengival. Os autores analisaram os seguintes parâmetros: forças desenvolvidas $\left(0,5,1\right.$ e $2 \mathrm{~N}$ ); angularidade da ponta ( $\mathrm{O}^{\circ}, 45^{\circ}$ e $90^{\circ}$ ), potência de regulagem do aparelho (baixa, média e alta) e tempo de instrumentação (10, 20, 40 e 80 segundos). Como resultados constataram que com aumento do tempo de instrumentação os defeitos provocados aumentaram quase que de maneira linear, tanto em extensão como em profundidade, fato este que ocorreu em todos os parâmetros estudados. Quanto à danificação da raiz em função da angularidade, força e potência, os melhores resultados foram obtidos quando a ponta trabalhou com ângulo de $0^{\circ}$, força lateral de 0,5 e 1,0N e com qualquer potência e quando se trabalhou com ângulo de $45^{\circ}$, força lateral de $0,5 \mathrm{~N}$ e potência baixa ou média. Os autores concluíram que uma faixa segura de uso em relação a esse 
parâmetro radicular para aparelhos deste tipo seria utilizando força de $0,5 \mathrm{~N}$, potência de regulagem baixa ou média e a menor angulação possível da ponta ativa.

Com o propósito de determinar "in vivo" se a combinação de instrumentos manuais com outros tipos de instrumentação (rotatórios e jatos abrasivos) podem aumentar a efetividade da raspagem e aplainamento radicular, HUERZELER et al. ${ }^{28}$ em 1998, desenvolveram estudo com 4 incisivos inferiores condenados por perda de suporte periodontal e presentes em 11 pacientes. Após obtenção de acesso cirúrgico à superfície radicular, de modo aleatório os incisivos foram assim tratados: 1) controle - sem tratamento; 2) dentes raspados por 5 minutos com cureta (método 1); 3) dentes raspados por 4 minutos com cureta mais 1 minuto com broca diamantada de granulação $15 \mathrm{ìm}$ (método 2) e 4 - dentes raspados por 3 minutos com curetas, mais um minuto com broca diamantada 15 ìm e mais um minuto de jato abrasivo (método 3). Após obtenção, as amostras foram analisadas em MEV e Microscopia de Força Atômica para analisar a rugosidade superficial e avaliar a efetividade da instrumentação. Em relação à efetividade em remover resíduos, todos os métodos (1, 2 e 3 ) foram satisfatórios, sendo o método 3 o mais eficiente dos 3 métodos estudados. Entretanto, o debridamento radicular mais efetivo "in vivo" requer a combinação de diferentes modalidades terapêuticas, quais sejam, curetas, brocas periodontais diamantadas e sistema de ar abrasivo.

Em artigo preparado pela $A A P^{01}$, em 2000, revisaram a eficácia e o papel dos raspadores ultra-sônicos na terapia periodontal. Estudaram vários tópicos como a seguir: quando se relaciona a redução de profundidade de sondagem e sangramento à sondagem estas duas variáveis podem ser alcançados tanto pelo US como pelo instrumento manual. Com relação a remoção de cálculo não há consenso sobre qual melhor método é mais eficiente na remoção do cálculo devido a inconsistência de metodologias ou projetos estudados e que a tentativa de completa remoção de cálculo requer extensiva instrumentação e pode significar extensa perda de cemento e dentina a qual pode induzir hipersensibilidade dentinária e aumentar a prevalência de pulpites e concluem que se o US for utilizado sobre média ou 
baixa potência e a ponta do instrumento estiver com ângulo próximo de zero provoca menos dano à superfície radicular. As alterações provocadas na superfície radicular por instrumentos US estão relacionados com algumas variáveis (tempo de contato da ponta sobre o dente, ângulo e pressão) e que devido a isto não se conclui qual método pode causar menos dano à superfície radicular. Em resumo, parece que saúde periodontal pode ser alcançada sem extensiva remoção de cemento por ambos tipos de instrumento.

Estudos recentes têm demonstrado que endotoxinas estão localizados na superfície do cemento radicular de dentes com envolvimento periodontal e não em seu interior, sendo sugerido que a superfície radicular pode ser tratada pouco agressivamente durante terapia periodontal. Assim em 2000, KOCHER et al..$^{35}$, propuseram novo instrumento e compararam a sua capacidade na remoção de depósitos bacterianos em bolsas profundas, sendo usados raspadores convencionais para análise comparativa. Utilizaram 51 pacientes com dentes expostos à doença periodontal, dos quais obtiveram 84 dentes. Uma superfície proximal foi raspada sem limite de tempo e outra superfície serviu como controle. Os seguintes instrumentos foram usados: 1) curetas Gracey (11 dentes); 2) US Piezoeletrico com potência média (18 dentes); 3) instrumento sônico convencional (16 dentes); 4) raspador sônico cuja ponta foi recoberta com tubo de teflon (16 dentes); e 5) raspador Periotor (15 dentes). Após extração, os dentes foram corados com verde malaquita e as seguintes áreas foram analisadas: áreas sem placa e cálculo, área com cálculo e área coberta somente com placa. Os resultados foram processados em sistema computadorizado de análise de imagem e mostraram que tanto as curetas $(97,5 \%)$, como o US $(92,2 \%)$ e o raspador sônico convencional $(92,1 \%)$ foram eficientes para remover grandes áreas de placa e cálculo da superfície radicular, com vantagens significativas para o grupo cureta que praticamente não deixou cálculo. Já os instrumentos raspadores sônicos com ponta modificada (84\%) e Periotor $(80 \%)$ apresentaram áreas menores de superfície livre de placa e cálculo, quando comparados com os instrumentos convencionais. Os autores concluíram que os instrumentos Periotor e raspadores sônico com ponta modificada podem ser adequados para remover 
depósitos moles sobre a superfície radicular, mas não efetivo na remoção do cálculo.

Com o propósito de comparar dois tipos de raspadores ultra-sônicos e um instrumento manual considerando o tempo, a remoção do cálculo, rugosidade da superfície ao exame por MEV, antes e após a instrumentação, em 2001 BUSSLINGER et al. ${ }^{10}$, propuseram-se a desenvolver estudo com 30 dentes humanos com cálculo supra e sub-gengival e divididos em 3 grupos conforme o tipo de instrumento usado para raspagem da superfície radicular: 1) cureta (10 dentes); 2) US Cavitron (10 dentes); e 3) US piezoeletrico Sonosoft 5 (10 dentes). Um único operador realizou movimentos de raspagem com curetas de apical para coronal, paralelamente ao longo eixo do dente, e com os dois tipos de US a ponta foi disposta paralela ao longo eixo do dente e os golpes de trabalho foram realizados perpendicularmente ao longo eixo do dente. Antes e após o procedimento, cada superfície escolhida foi fotografada com câmera fotográfica digital e a imagem processada para uso em computador para documentação e determinação da quantidade de cálculo em programa de computador especialmente desenhado para este fim. Ainda antes e após a instrumentação, os espécimes foram moldados em suas áreas raspadas com silicona, com 0 objetivo de se obter réplicas que foram preparadas para análise em MEV. As réplicas das áreas de interesse antes e depois do experimento foram então avaliadas perfilometricamente para mensuração da rugosidade superficial. A análise em MEV foi feita para determinar a quantidade de estrutura dental perdida e de cemento ainda presente, danos, trincas, defeitos em goiva, frestas e possíveis resíduos. Os resultados revelaram que o tempo necessário para raspagem foi significantemente menor para o instrumento US piezoeltrico $(74,1 \mathrm{~s}$.). Cálculos remanescentes foram poucos e mostraram-se similares para os três grupos, não havendo diferenças significativas entre eles. Os valores finais relacionados à rugosidade da superfície foram significantemente piores para o grupo US piezoeletrico $(2,02)$ se comparados com os grupos cureta $(1,42)$ e US Cavitron $(1,36)$. A avaliação ao MEV revelou que houve lisura superficial nos três grupos, sendo que o grupo cureta produziu maior perda de substância dentária, enquanto que o Cavitron 
produziu a menor perda de substância, situando-se 0 instrumento piezoelétrico com perda média de substância. Os autores concluíram que todos os três instrumentos de raspagem testados podem produzir superfície radicular livre de cálculos quando corretamente aplicados; as curetas manuais produziram superfície lisa após instrumentação; o aparelho Cavitron produziu superfície radicular lisa conservada em tempo moderadamente curto; e finalmente, o trabalho com o instrumento ultra-sônico piezoelétrico é o mais rápido.

Em trabalho "in vitro", FEIST ${ }^{21}$, em 2002, verificou a adesão e a proliferação de fibroblastos de gengiva humana sobre superfícies radiculares tratadas com laser de Er:YAG ou instrumento manual, valendo-se de 27 dentes uniradiculares com doença periodontal recém extraídos. A amostra foi dividida em três grupos: A) superfície radicular aplainada com curetas Gracey; B) irradiadas com fibra periodontal, energia de $35 \mathrm{~mJ} /$ pulso e C) irradiadas com energia de $59 \mathrm{~mJ} /$ pulso. Fragmentos de $5 \times 6 \mathrm{~mm}$ obtidos foram autoclavados, plaqueados com $10^{3}$ células e acompanhados por $1,2 \mathrm{e}$ três dias. Os espécimes foram processados em MEV e a contagem de células foi feita sobre as eletromicrografias com o auxílio de uma grade quadriculada. Os fibroblastos de gengiva humana aderiram e proliferaram sobre todas as superfícies tratadas. Nos dias 1 e 2 o número de células sobre os fragmentos do grupo $B$ foi significantemente maior do que sobre os dos outros dois grupos. Após três dias do plaqueamento as células dos grupos $A$ e $B$ apresentaram total confluência e o número de células sobre os fragmentos do grupo $B$ foi significantemente maior do que sobre os do grupo $C$. Baseados nestes resultados pôde concluir que as superfícies tratadas com laser de Er:YAG (35 mJ/pulso) favorecem a adesão e a proliferação de fibroblastos.

\subsection{Efeitos da Desmineralização sobre a Superfície Radicular}

Em 1982 DALY $^{18}$ investigou o efeito anti-bacteriano do ácido cítrico contra depósitos de placa presentes sobre superfícies radiculares "in vitro". Cultura de microrganismos aeróbicos e anaeróbicos foram obtidas a partir da 
placa dentobacteriana de 20 dentes com DP. A seguir 10 dentes foram expostos ao ácido cítrico pH1 por três minutos e então lavados com soro fisiológico por um minuto. Isso posto, nova amostra de placa foi obtida adjacente à remoção da primeira e submetida ao mesmo processo de cultura bacteriana anterior. Um grupo controle usou somente água estéril e as amostras foram colhidas e cultivadas conforme o grupo experimental. Os resultados indicaram que a aplicação de ácido cítrico em todos os casos reduziu o crescimento de colônias no grupo experimental.

Trabalhando "in vitro", PITARU et al. ${ }^{51}$, em 1984, analisaram a migração, adesão e crescimento de fibroblastos de gengiva humana sobre 4 raízes de dentes suínos, apresentando superfície de dentina desmineralizada, cemento desmineralizado, dentina mineralizada e cemento mineralizado. Após o preparo dessas condições, os fragmentos representativos obtidos foram colocados em cultura de fibroblastos e acompanhados por 1, 3 e 6 dias. Verificaram que as células começaram a migrar e aderir na periferia dos espécimes imediatamente após colocação em meio de cultura, formando-se pontes celulares entre a superfície radicular e a placa de Petri nas primeiras 24 horas e que aumentaram gradualmente em número e tamanho em todo 0 período experimental. As superfícies desmineralizadas foram mais efetivas em estimular a migração, adesão e a orientação celular do que as superfícies não desmineralizadas, e, por sua vez, as superfícies de dentina desmineralizadas foram mais efetivas que as de cemento desmineralizadas. Esses resultados levaram os autores a considerarem que a desmineralização produz efeitos estimulantes da cura da ferida e sugerem que a dentina desmineralizada representa a superfície dental mais efetiva nesse sentido.

POLSON et al. ${ }^{50}$, em 1984, avaliaram a natureza da superfície radicular em relação aos efeitos da raspagem e aplainamento unicamente ou acompanhados por condicionamento tópico com ácido cítrico aplicado por 3min, seguindo-se lavagem com soro fisiológico. Para tanto, extraíram 6 dentes de macacos, que foram submetidos ao aplainamento na metade coronal da superfície radicular para eliminar cemento e ligamento periodontal. A seguir, 3 dos dentes foram condicionados com ácido cítrico $\mathrm{pH} 1$ por 3 minutos e após lavados com soro fisiológico e preparados para leitura em 
MEV. As raízes apenas raspadas apresentaram superfícies irregulares, correspondentes à camada de impregnação, enquanto que os dentes tratados com ácido cítrico exibiram túbulos dentinários abertos e zonas intertubulares com material fibrilar. Assim, os autores consideraram que o ácido cítrico é um dos mais efetivos na remoção da camada de impregnação, exposição das fibras da dentina intertubular e exposição e ampliação dos túbulos dentinários em forma de funil, devido à ação preferencial sobre a dentina peritubular mais altamente mineralizada

Alguns anos mais tarde,TANAKA et al. ${ }^{62}$, em 1989, estudaram a ação do ácido cítrico sobre o cálculo e placa dentobacteriana persistentes após raspagem radicular $\infty m$ curetas em 5 dentes humanos com cálculo aderido clinicamente visível. Em cada dente foi eleita uma superfície proximal, que foi raspada e dividida ao meio com um disco diamantado fino. Uma metade foi condicionada com ácido cítrico ( $\mathrm{pH} 1)$, brunida com bolinha de algodão por 3 minutos (teste) e imersa em solução salina para lavagem. A outra metade foi apenas brunida com bolinhas de algodão (controle) em solução salina por 3 minutos. As superfícies tratadas foram processadas para análise em MEV. Como resultados, os autores observaram que os espécimes controle mostravam estrias deixadas pela cureta, a superfície do cálculo estava lisa, porém também exibiam estrias de raspagem; além disso, grande número de bactérias foi identificado nas margens entre o cálculo remanescente e 0 cemento. Nos espécimes do grupo teste, não encontraram bactérias presentes nas margens do cálculo, a superfície do cálculo foi alisada e aparentemente descalcificada, permitindo a visualização de alguns cocos em seu interior. Os autores concluíram que o condicionamento por brunidura com ácido cítrico removeu virtualmente as bactérias e descalcificou pequenos cálculos sub-clínicos, deixados sobre a superfície dental pela ineficácia incontrolável do procedimento de raspagem radicular em remover todo o cálculo, de modo que ressaltaram poder ser esse o maior benefício da aplicação do ácido.

Por sua vez, CHAVES et al. ${ }^{12}$, em 1993, estudaram a ação do ácido cítrico sobre dentes humanos com comprometimento periodontal, em MEV. Dentes unirradiculares foram selecionados e divididos em cinco grupos: grupo 
1- 10 dentes sem comprometimento periodontal; grupo 2- 10 dentes acometidos por DP, sem nenhum tratamento; grupo 3- 10 dentes com DP que receberam apenas condicionamento com ácido cítrico $(\mathrm{pH} 1)$; grupo 4- 10 dentes com DP que receberam apenas raspagem e alisamento radicular; grupo 5-10 dentes com DP que receberam raspagem e alisamento radicular + condicionamento com ácido cítrico por 3 minutos. Os resultados mostraram que no grupo 1 a superfície radicular estava coberta por cemento superposto à dentina; no grupo 2, massas densas de cálculo cobriram várias áreas da superfície do cemento, podendo ser observadas algumas bactérias ao redor e entre os espaços do cálculo; no grupo 3 pôde ser observado cemento por toda a superfície, mas não uniformemente, e presença de cálculo; no grupo 4 as superfícies apresentaram-se lisas, planas e regulares, com a presença normal de estrias paralelas características da raspagem e presença de camada de impregnação ("smear layer") cobrindo túbulos dentinários nas áreas em que a dentina foi exposta; e, no grupo 5 a superfície radicular mostrou semelhança com o grupo anterior e ausência de camada de impregnação, com túbulos dentinários desobstruídos e áreas intertubulares desmineralizadas e com fibras colágenas expostas.

Com o objetivo de avaliar a formação dessa camada de impregnação ("smear layer") pela raspagem radicular com vários instrumentos e a sua remoção e exposição de fibras colágenas pelo condicionamento por $2 \mathrm{~min}$ com EDTA a 24\%, BLOMLÖF et al. ${ }^{09}$, em 1997, utilizaram dentes humanos com periodontite e divididos em 6 grupos: 1-instrumentados com US; 2instrumentados com US + condicionamento com EDTA; 3 instrumentados com curetas; 4 instrumentados com cureta + condicionamento com EDTA; 5instrumentados com broca diamantada e 6- instrumentados com broca diamantada + condicionamento com EDTA. Após os grupos serem tratados conforme descrição acima foram preparados para análise em MEV. Puderam observar que todos os tipos de instrumentos, inclusive o ultra-som, causaram formação da camada de impregnação sobre a superfície radicular, cobrindo por completo os túbulos dentinários; por sua vez, o EDTA foi efetivo na remoção dessa camada, deixando filamentos de colágeno expostos sobre as superfícies radiculares condicionadas. Os autores concluíram que o 
condicionamento de superfícies radiculares tratadas com EDTA a $24 \%$ foi eficiente na remoção da superfície hipermineralizada e da camada de impregnação, acompanhada pela exposição de colágeno sem comprometimento do potencial de cicatrização dos tecidos circundantes.

ZAMAN et al. ${ }^{68}$, em 2000, avaliaram quantitativamente a migração, adesão e orientação de células do ligamento periodontal humano (HPLC) sobre cemento e dentina desmineralizados após raspagem e aplainamento radicular de dentes periodontalmente doentes. Utilizaram dentes extraídos em razão de comprometimento por doença periodontal, os quais foram raspados e aplainados de modo que metade do dente permaneceu com cemento remanescente e a outra metade continha dentina exposta. Isto posto, procederam à desmineralização com diferentes meios. A análise do comportamento em cultura de células não mostrou diferença significante no índice de adesão e orientação de HPLC para o cemento comparado com a dentina, embora tenha havido diferenças significativas na adesão e orientação celular para dentina desmineralizada com EDTA e ácido cítrico em relação à dentina não desmineralizada e para as 3 superfícies de cemento desmineralizadas em relação à superfície do cemento não desmineralizada. Os autores concluíram que a utilização de ácido cítrico e EDTA pode aumentar a adesão e orientação de HPLC na superfície radicular e que não é necessário remover excessivamente o cemento quando procedimento de desmineralização é utilizado.

A Revisão de Literatura formulada parece evidenciar nitidamente a preocupação dos autores ao longo dos anos de avaliar a importância dos diferentes procedimentos de tratamento da superfície radicular, visando não só o provimento de condições propícias para o estabelecimento e preservação da higiene bucal, como também preenchendo requisitos biológicos para que se possa ter melhor efetivação dos processos de cura da ferida cirúrgica periodontal, favorecendo a reconstrução do periodonto. Dessa forma, o tratamento adequado da raiz está voltado essencialmente e é fundamental para o provimento de saúde e estabelecimento das condições necessárias e propícias à aplicação dos procedimentos preventivos em Periodontia. 
Todavia, pode-se claramente perceber que, a despeito do grande número de trabalhos publicados em função da importância desse procedimento, ainda hoje não se chegou a um consenso mais amplo sobre 0 tipo de tratamento que produza superfícies radiculares com características mais apropriadas para esse fim, justificando, assim, a realização deste trabalho. 


\section{PROPOSIÇÃO}

Considerando a importância e a variabilidade de recursos disponíveis e a procura de outros meios para o tratamento periodontal adequado da superfície radicular, por meio de MEV empreendeu-se projeto de pesquisa com a aplicação de diferentes meios de preparo radicular, visando:

1- Analisar "in vitro" os efeitos da instrumentação manual e ultra-sônica na superfície radicular;

2- Identificar possíveis efeitos benéficos provenientes da associação desses meios na adequacidade da superfície radicular tratada;

3- Verificar se a desmineralização da superfície radicular com ácido cítrico proporciona mudanças nas superfícies radiculares, tornando-as mais compatíveis com as propostas literárias. 


\section{MATERIAL E MÉTODOS}

Ressalte-se, de início, que o presente projeto foi submetido à apreciação do Comitê de Ética e Pesquisa da Faculdade de Odontologia de Bauru, tendo sido aprovado conforme parecer no 05/2002

Foram utilizados 66 dentes uni-radiculares obtidos do banco de dentes da Disciplina de Periodontia da Faculdade de Odontologia de Bauru, com a presença de cálculo e superfície visível de doença periodontal, armazenados em soro fisiológico (Solução de Cloreto de Sódio a 0,9\% Darrow Laboratórios - Brasil). Os dentes foram avaliados com lupa (Lactona 4x) para examinar, antes da instrumentação, concavidades e convexidades excessivas, que dificultariam a leitura pela microscopia eletrônica de varredura.

Para viabilizar o tratamento adequado dos dentes conforme as variáveis propostas no trabalho, os dentes tiveram que ser preparados para serem fixados, por meio de resina concise, a cápsulas vazias de amálgama, formando o bloco de trabalho (Figura 2)

O preparo dos dentes constou, inicialmente, de seccionamento das raízes ao meio no sentido longitudinal deixando as coroas intactas, descartando uma das metades seccionadas e assim formando superfícies radiculares no sentido vestíbulo-lingual ou mésio-distal, dependendo da melhor localização do cálculo para instrumentação. Esses cortes foram feito com discos de carburundum, sob refrigeração (Figura 1). 


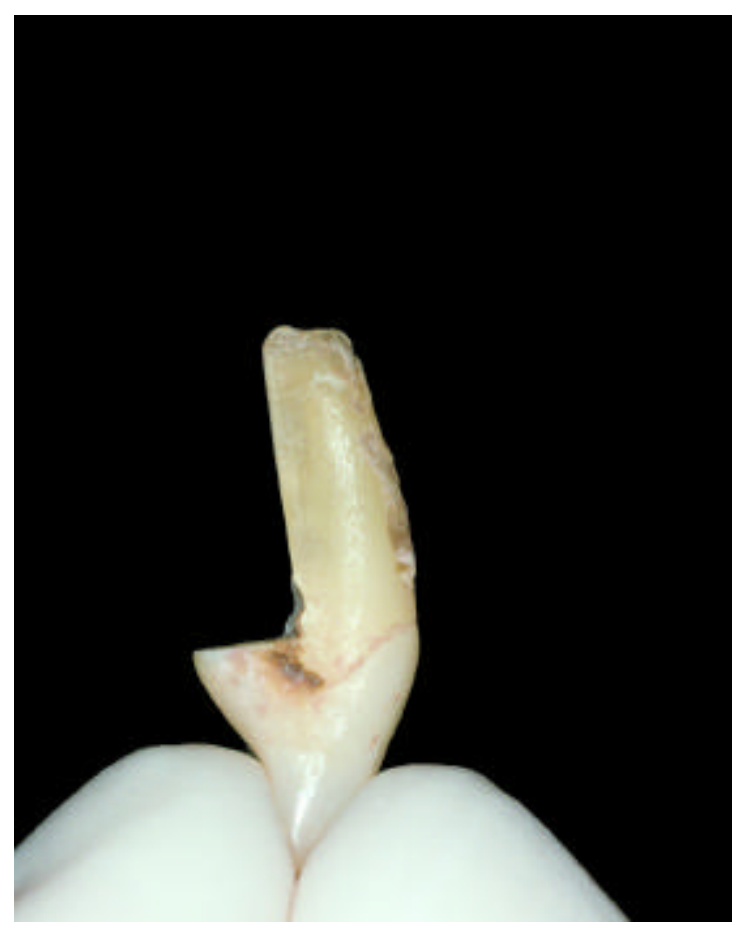

FIGURA 1 - Vista do objeto de estudo mostrando o corte no longo eixo do dente antes da instrumentação para evitar acúmulo excessivo de impurezas na superfície a ser instrumentada e manutenção da coroa intacta com intuito de sugerir a possibilidade de melhor apoio e copiar a situação clínica possível.

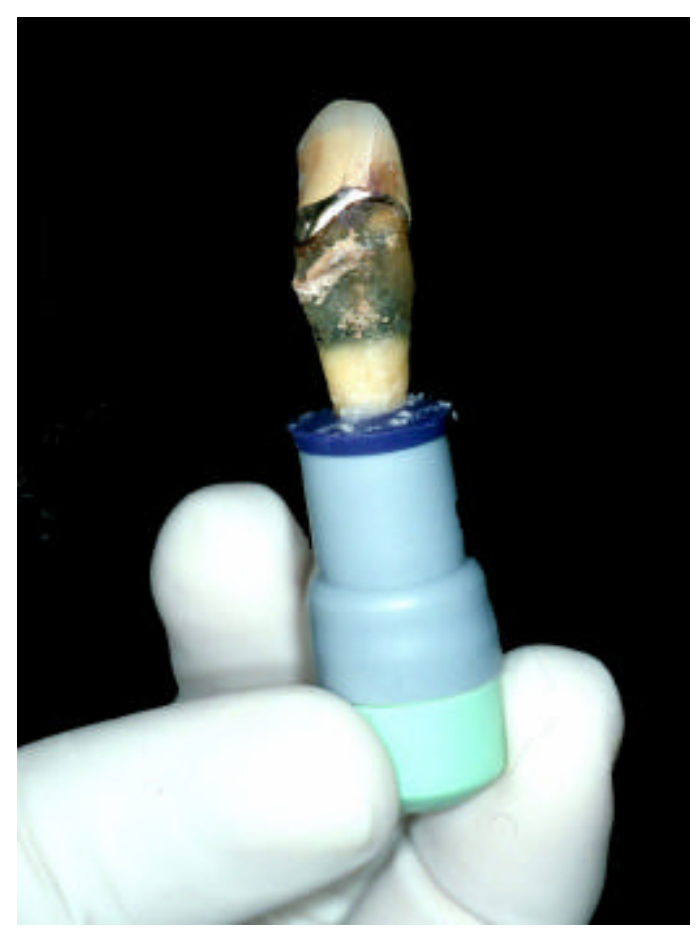

FIGURA 2 - Vista do bloco de trabalho demonstrando a fixação do terço apical em cápsulas de amálgama com resina composta (Concise) deixando a superfície a ser instrumentada livre. 
Em seguida, lateralmente às áreas a serem raspadas, foram impressas marcas de referência com brocas carbide no 1/2 em alta rotação, sob refrigeração e localizadas uma $1 \mathrm{~mm}$ apicalmente à junção cementoesmalte e outra à distância padronizada de $5 \mathrm{a} 7 \mathrm{~mm}$ apicalmente à primeira, em função da extensão do cálculo existente, de modo que os fragmentos a serem lidos em MEV tivessem todos aproximadamente o mesmo tamanho (Figura 3).

Com o objetivo de facilitar a instrumentação, os dentes, em seus 3 a $4 \mathrm{~mm}$ apicais, foram então incluídos em resina composta autopolimerizável (Concise), contida em cápsulas de amálgama, formando o bloco de trabalho, no qual a superfície com cálculo a ser instrumentada ficou amplamente exposta.

Os blocos foram estabilizados em uma prensa Morsa (Figura 4), para que a instrumentação periodontal conferisse a maior fidelidade possível em relação à instrumentação clínica in vivo. 


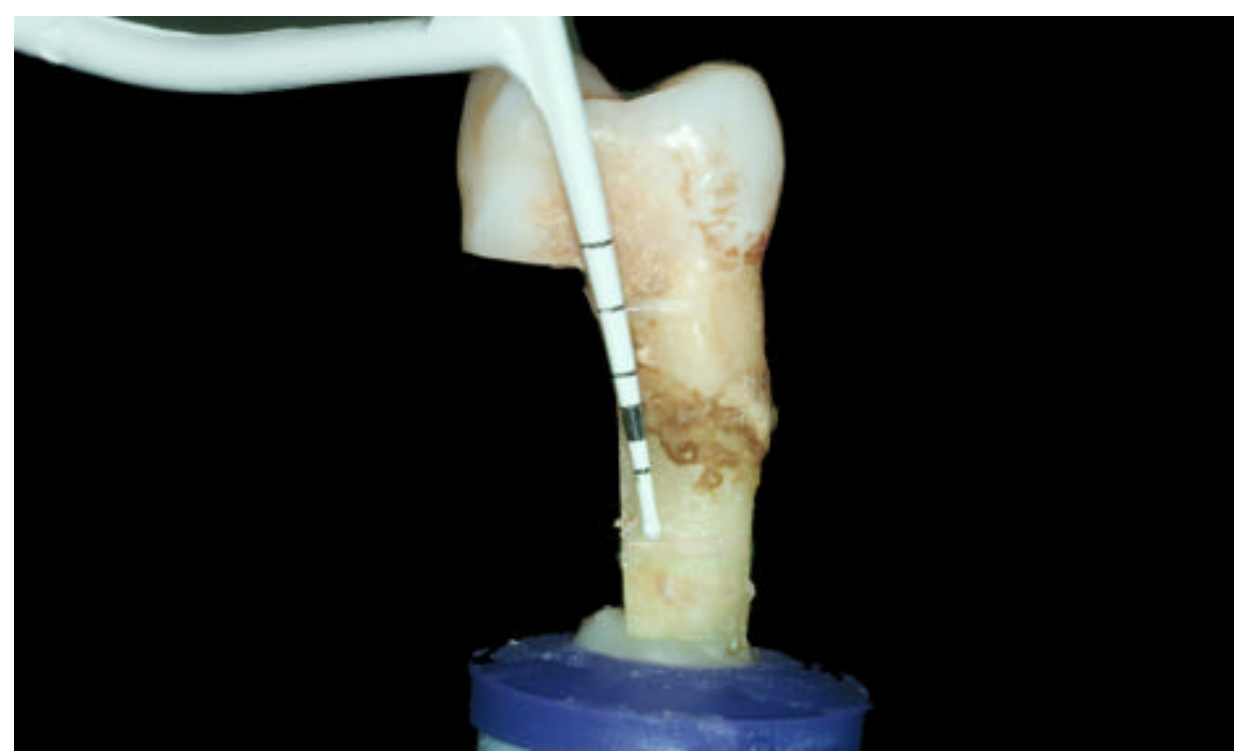

FIGURA 3 - Vista lateral da superfície mostrando sulcos produzidos lateralmente às áreas a serem raspadas delimitando a quantidade de superfície a ser instrumentada e o tamanho do futuro fragmento $(5 \mathrm{a} 7 \mathrm{~mm})$

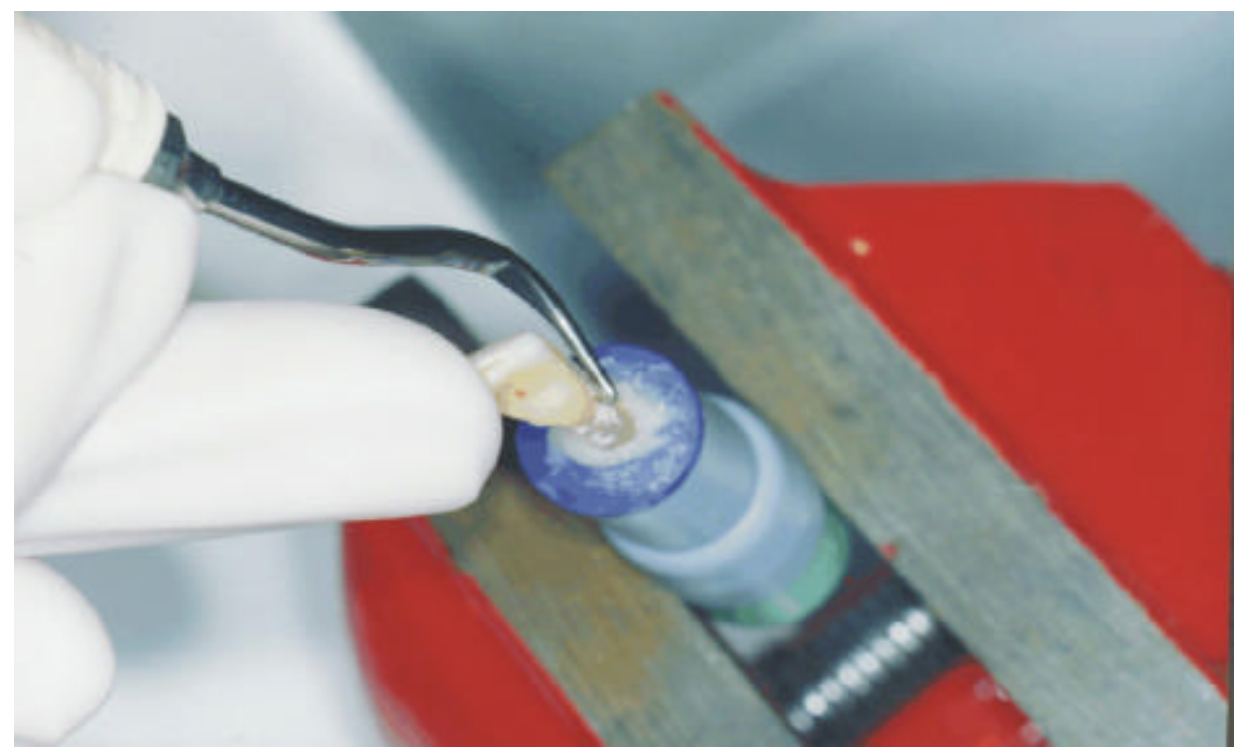

FIGURA 4 - Vista do objeto a ser instrumentado estabilizados na prensa Morsa, para facilitar os movimentos de instrumentação. 
Os instrumentos utilizados no trabalho foram curetas Gracey \#5/6 (Hu-friedy-USA) e pontas convencionais do aparelho ultra-sônico Profi III Bios (Dabi Atlante), trabalhando com potência média (SMART et al, $1990^{60}$; FLEMMIG et al, $1998^{23}$; KOCHER et al. $.^{35}, 2000$ ) e seguindo as normas amplamente aceitas de uso desses instrumentais (PATTISON; PATTISON) ${ }^{49}$. Enquanto metade dos dentes permaneceram com a superfície mineralizada, a outra metade foi desmineralizada imediatamente após a primeira instrumentação e antes de outra seguinte. Com isso foi possível elaborar a formação de 6 grupos com 10 dentes cada, aleatoriamente escolhidos e assim constituídos: Grupo 1 - dentes mineralizados utilizando instrumentação manual com curetas; Grupo 2 - dentes mineralizados utilizando instrumentação ultra-sônica; Grupo 3 - dentes mineralizados utilizando instrumentação ultra-sônica seguida de instrumentação manual com curetas; Grupo 4 - dentes inicialmente instrumentados com curetas, desmineralizados e novamente instrumentados com curetas; Grupo 5 - dentes inicialmente instrumentados ultra-sonicamente, desmineralizados e novamente submetidos à instrumentação ultra-sônica; e, Grupo 6 - dentes inicialmente instrumentados ultra-sonicamente, desmineralizados e novamente instrumentados agora com curetas manuais.

A desmineralização dos dentes foi feita inequivocamente após a primeira e antes da segunda instrumentação pertinente ao grupo, usando gel da associação de ácido cítrico pH 1 e tetraciclina (Decalcific Gel-Dentoflex), aplicados por 3min, seguindo-se lavagem abundante com soro fisiológico, seguida pela $2^{\mathrm{a}}$ instrumentação com as mesmas normas anteriores.

Os 6 dentes remanescentes formaram o Grupo 7, considerado controle e tendo como características tratarem-se de dentes com doença periodontal, recobertos por cálculo visível e que não experimentaram nenhum tipo de instrumentação, conseqüentemente o grupo controle não foi considerado na análise estatística.

A raspagem foi realizada por um único pesquisador, com força e movimentos semelhantes aos utilizados clinicamente, no sentido do longo eixo da raiz e de apical para coronal. Nos grupos em que se utilizaram curetas determinourse o número de 30 golpes instrumentais (O'LEARY; 
KAFRAWY, 1983) $)^{47}$, como parâmetro final da instrumentação radicular(Figura 5). . Saliente-se que a cada 30 golpes as curetas Gracey foram afiadas com pedras Arkansas (Hu-Friedy-USA), seguindo recomendações de PATTISON; PATTISON ${ }^{49}$

O uso do aparelho ultra-sônico foi estimado entre 2 a 3 minutos por dente, utilizando potência média com irrigação, conforme orientação de WOODROF et al. ${ }^{66}, 1975$; SMART et al. ${ }^{60}, 1990$; FLEMMIG et al. ${ }^{23}, 1998$ (Figura 6).

Após o término da instrumentação as raízes dos dentes foram seccionadas novamente, agora no sentido transversal e em dois níveis, determinados pelas marcas de referência a $1 \mathrm{~mm}$ apical à JCE e 5 a $7 \mathrm{~mm}$ apical à primeira, de modo a incluir no fragmento interessado toda a região trabalhada. Esses cortes foram feitos com brocas carbide n. 171 (SS White) em alta rotação, sob refrigeração abundante.

Os fragmentos obtidos, identificados por grupos, foram acondicionados em embalagens plásticas contendo soro fisiológico, ficando armazenados até a preparação para leitura em microscopia eletrônica de varredura. 


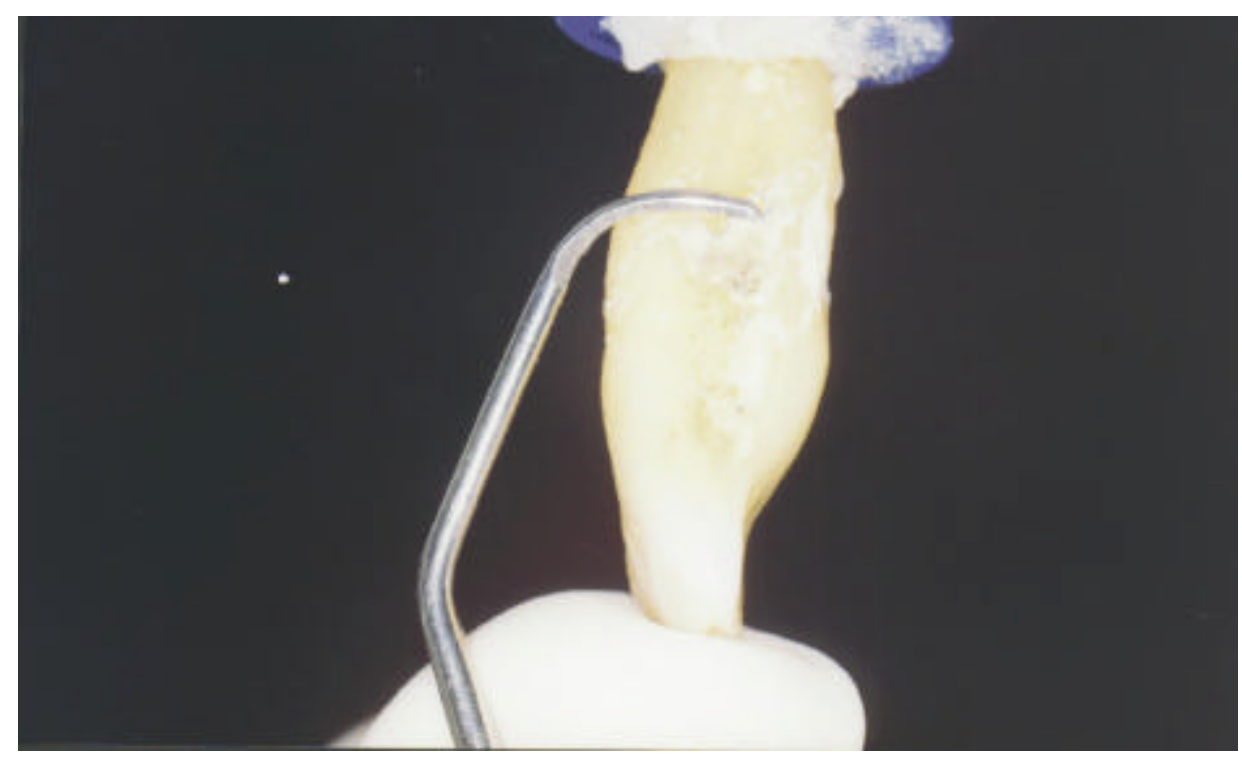

FIGURA 5 - Vista demonstrando forma de apoio e adaptação da lâmina do instrumento e movimentos de tração no sentido ápico-coronário utilizando cureta Gracey 5/6.

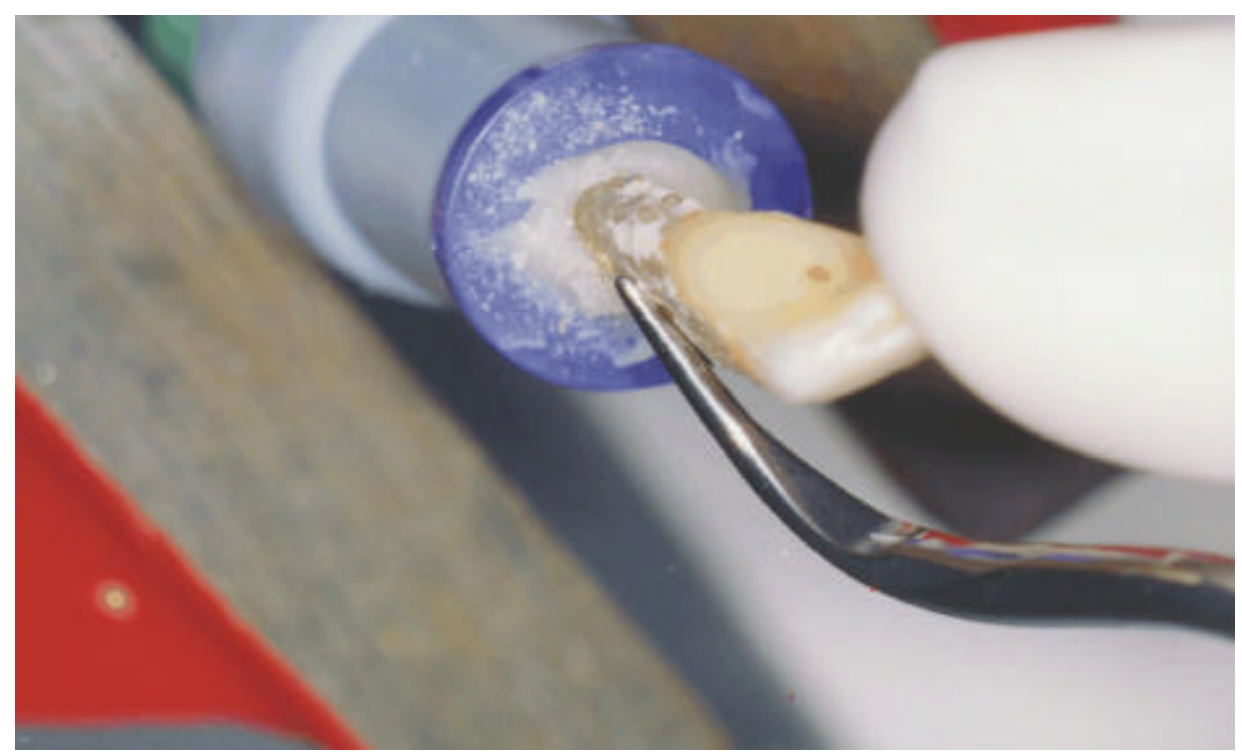

FIGURA 6 - Vista demonstrando o modo de aplicação da ponta do instrumento (US) sobre a superfície radicular 
Para preparar os fragmentos para leitura em MEV, os espécimes foram secos inicialmente com papel absorvente e depois com ar condicionado por uma noite. Após desidratação em álcool absoluto por 2 minutos e secagem novamente com papel absorvente, os fragmentos foram colados com esmalte de unha em uma mesa circular de $1 \mathrm{~cm}$ de diâmetro, especialmente preparada em alumínio (Figura 7).

Após a colagem, os fragmentos foram colocados no aparelho "Sputer Coatering" (BAL-TEC - SCD 050 - USA), no qual a superfície a ser estudada foi impregnada com a camada superficial de ouro necessária para a leitura em MEV (Figura 8).

Isto posto, o conjunto preparado foi levado ao MEV, no qual foram feitas as leituras com aumentos de 35X, 100X e 350X utilizando a porção central do fragmento para as leituras principais e $750 \mathrm{X}$ e $1500 \mathrm{X}$ para confirmação de eventuais dúvidas de identificação do detalhe da leitura. Esses procedimentos foram feitos usando o microscópio eletrônico JEOL (JSM-T 220A), regulado em 20Kv. Após a seleção do campo para leitura, os fragmentos foram fotografados com filmes Fuji Acros ASA 100, posteriormente revelados em cópia branca e preta no tamanho 9x12, possibilitando as condições para obtenção dos resultados a serem avaliados.

A leitura das características superficiais interessadas foi feita por um único examinador previamente treinado e calibrado. $O$ treinamento do examinador consistiu da análise e discussão de fotomicrografias que apresentavam os vários escores dos índices avaliados com um segundo pesquisador. A calibração foi realizada através da análise de 60 fotomicrografias, em dois momentos distintos, com intervalos de 3 dias de maneira cega e aleatória. As análises das 180 fotomicrografias foram realizadas em duas leituras cegas, independentes e aleatórias, levantando os dados de identificação da rugosidade superficial, persistência de cálculo e perda da substância dental. Após a obtenção dos valores, para cada elemento amostral, foi obtido a mediana, sendo esta representativa do elemento. 


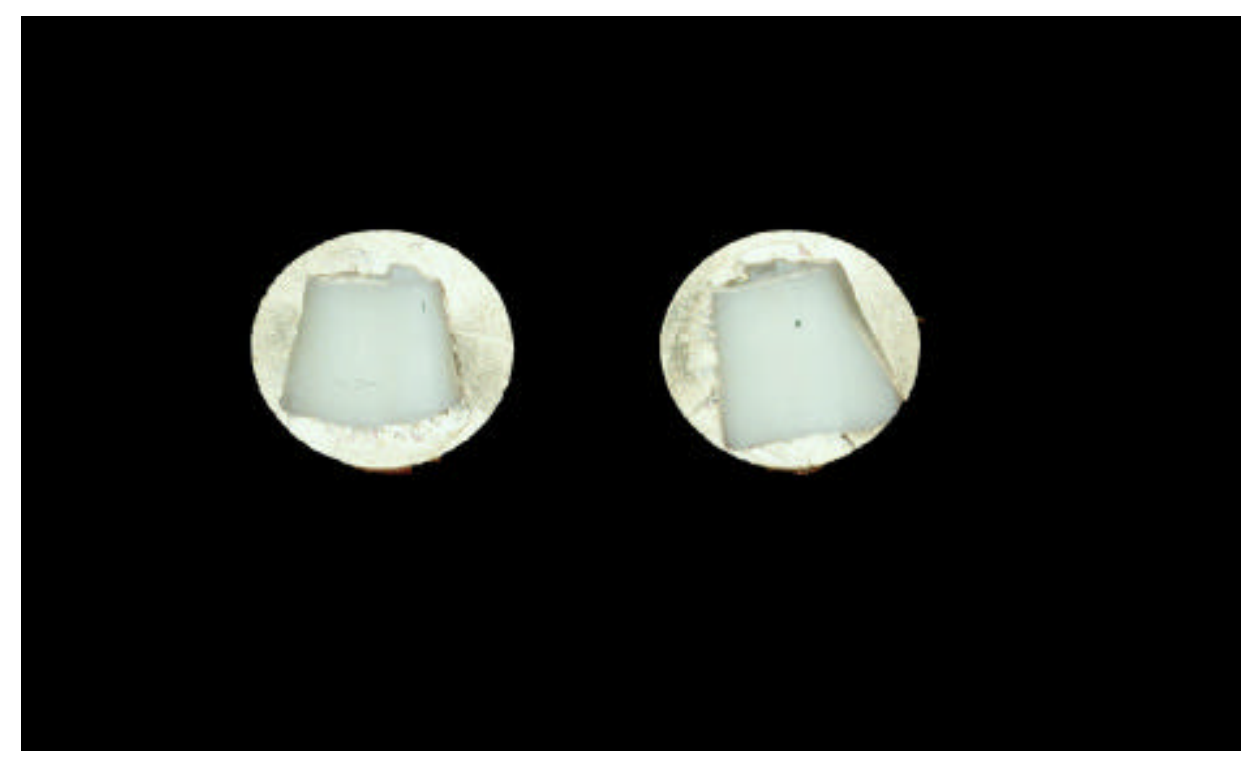

FIGURA 7 - Vista dos fragmentos obtidos após seccionamento com brocas, e colados na base metálica, prontos para serem impregnados com ouro

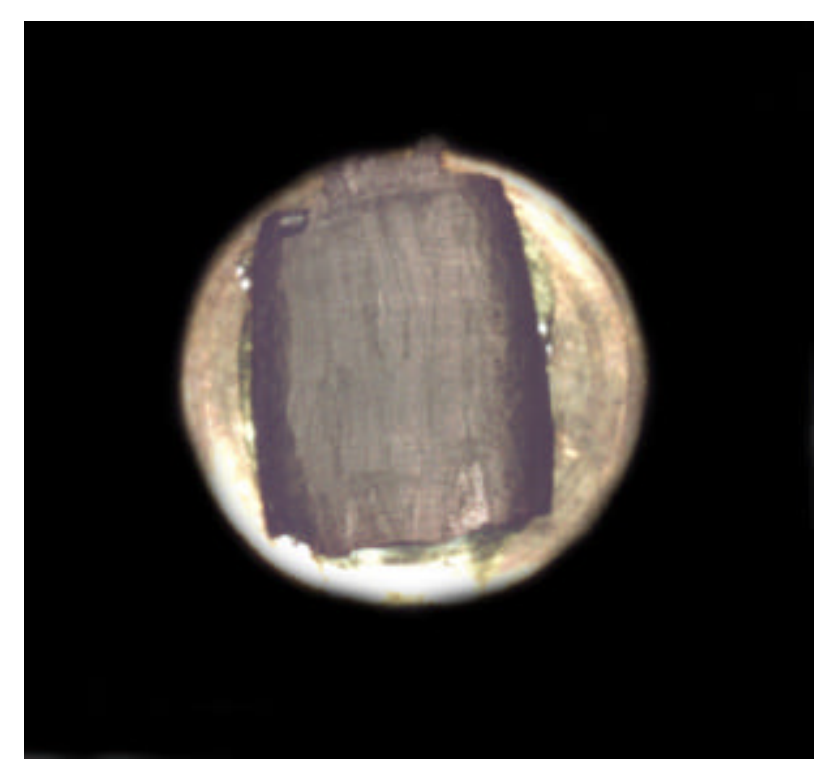

FIGURA 8 - Vista dos fragmentos impregnado com ouro e pronto para análise e obtenção de imagem em MEV 
A rugosidade superficial foi analisada de acordo com 0 índice de rugosidade superficial de varredura (IRS) de MEYER e LIE $^{40}$ (1977), que respeita os seguintes critérios:

1) superfícies lisas e uniformes ou ligeiramente rugosas, porém sem sinais do instrumento usado;

2) maioria das áreas ligeiramente rugosas com algumas regiões onduladas, porém sem marcas óbvias do instrumento usado;

3) áreas definitivamente onduladas e algumas marcas do instrumento, porém áreas também relativamente uniformes; e,

4) superfícies definitivamente onduladas e com riscos do instrumento usado, abrangendo a maioria das áreas.

A presença de cálculo residual foi identificada de conformidade com o índice de cálculo remanescente (ICR) de LIE e MEYER ${ }^{37}$ (1977), que usa os seguintes critérios:

1) nenhum cálculo remanescente na superfície radicular;

2) pequenos manchas de material estranho, provavelmente consistindo de cálculo;

3) manchas definidas de cálculo confinadas a áreas menores; e,

4) quantidades consideráveis de cálculo remanescente, aparecendo como uma ou algumas manchas volumosas ou como várias manchas menores distribuídas na superfície tratada.

A perda da substância dental foi avaliada pelo índice correspondente (IPSD), também de LIE e MEYER ${ }^{37}$ (1977), usando os seguintes critérios:

1) nenhuma perda detectável de substância;

2) ligeira perda de substância dental limitada a áreas localizadas, estando a maioria do cemento intacta;

3) perda definida de substância dental na maior parte da superfície tratada, porém sem marcas profundas do instrumento na dentina, podendo o cemento estar ausente em algumas áreas; e,

4) perda considerável da substância dental, com marcas profundas do instrumento na dentina, estando a maioria do cemento removida. 


\subsection{Análise Estatística}

A análise da concordância intra-examinador foi testada utilizando o teste Kappa.

As variáveis qualitativas ordinais representadas pelos índices de cálculo residual (ICR), rugosidade superficial (IRS) e perda de substância dentária (IPSD) foram avaliadas comparando os seis grupos experimentais utilizando o modelo estatístico não paramétrico de Kruskal-Wallis, sendo os dados transformados em postos (ranks).

A relação entre as medianas dos escores dos índices foi testada através do teste de correlação não paramétrica de Spearman.

Foi adotado como nível de significância o valor de 0,05. Desta forma, se $p>0,05$ a hipótese de nulidade $(\mathrm{Ho})$, pela qual todos os grupos apresentariam valores semelhamentes seria aceita. Caso $p \leq 0,05$, então Ho seria rejeitada. Neste caso, a comparação entre os postos médios das amostras seria efetuada através do teste de comparações múltiplas de Dunn, a fim de se detectar entre quais grupos havia diferenças estatisticamente significantes.

Todos os cálculos foram realizados com o auxilio dos softwares estatísticos GraphPad InStat ${ }^{\circledR}$ version 3.00 for Windows 95 (GraphPad Software, San Diego California USA, www.graphpad.com") e GMC versão 8.1 - 2001 (http://www.forp.usp.br/restauradora/gmc/gmc.html). 


\section{RESULTADOS}

Embora os resultados do grupo controle não tenham sido considerados na análise estatística por não terem sido tratados, a variável passível de ser amostrada nesse grupo seria apenas a presença de cálculo, que corresponderia ao índice máximo de cálculo residual.

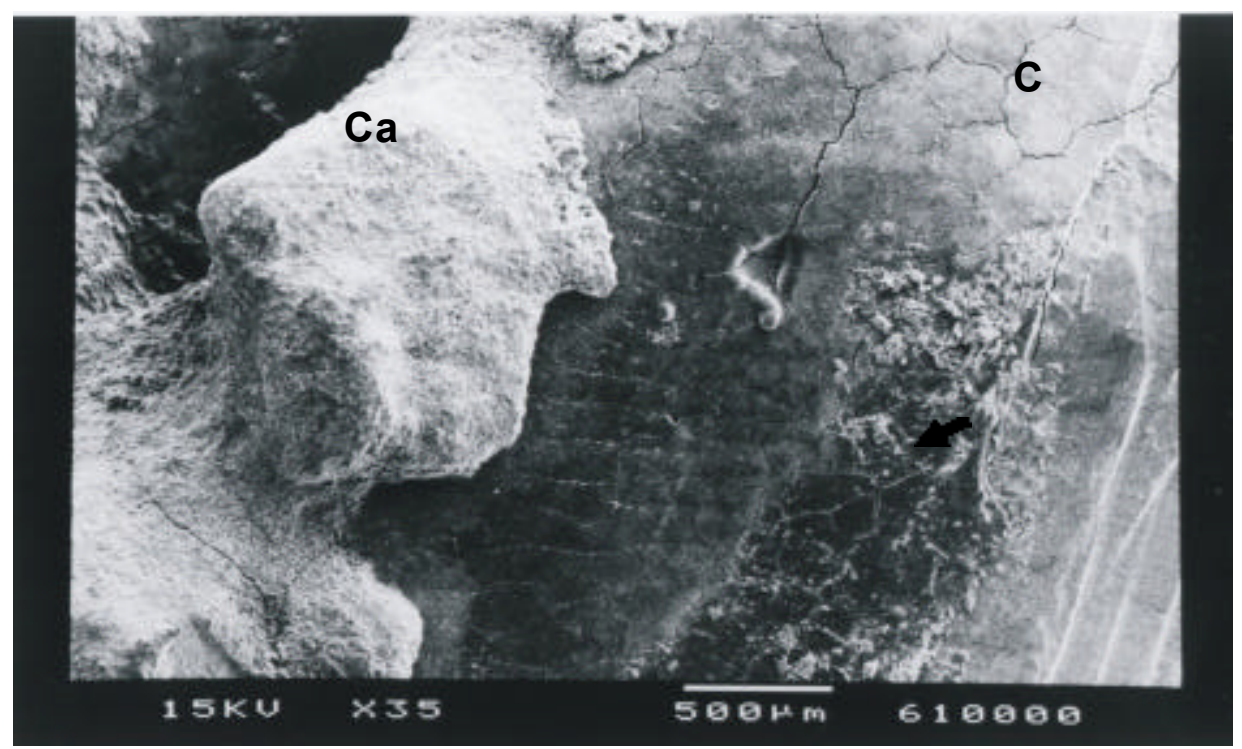

FIGURA 9 - Grupo Controle

FIGURA 9.A - Imagem ilustrativa demonstrando áreas de reabsorção de cemento (vide seta) em aumento de 35X - C- cemento; Cacálculo

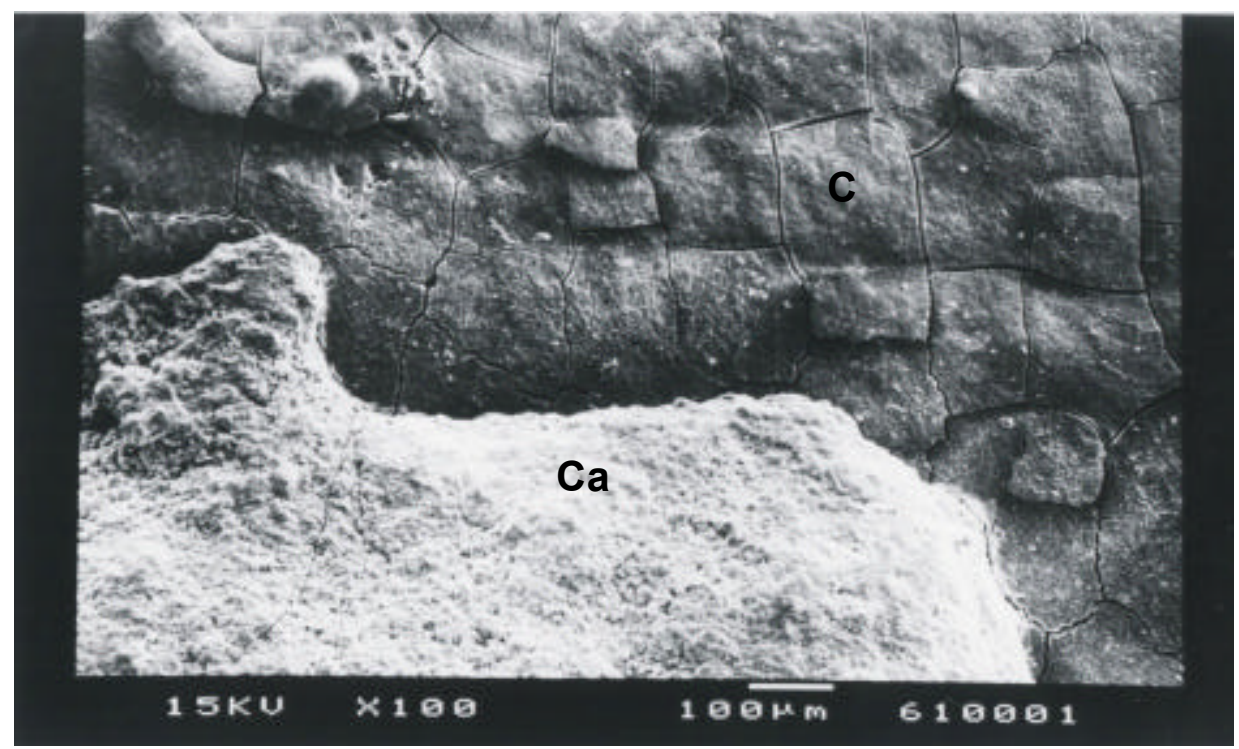

FIGURA 9.B - Imagem ilustrativa demonstrando presença de cálculo (Ca) com sua superfície áspera e porosa aderida ao cemento (C) 
Portanto, todas as alterações produzidas pela instrumentação apresentaram variáveis diferentes do controle.

Para que se pudesse analisar os diferentes índices examinados e a variação entre os grupos experimentais estudados, avaliou-se inicialmente o nível de concordância intra-examinador utilizando o teste de Kappa, o qual demonstrou concordância moderada, cujo termo significa avaliação entre bom e regular, entre os 3 índices utilizados (ICR, IRS e IPSD).

\begin{tabular}{|c|c|}
\hline Valor de Kappa & Significado \\
\hline 1 & Perfeita \\
\hline $0,81-0,99$ & Muito boa \\
\hline $0,61-0,80$ & Boa \\
\hline $0,41-0,60$ & Regular \\
\hline $0,21-0,40$ & Fraca \\
\hline $0-0,20$ & Muito fraca \\
\hline
\end{tabular}

Fonte: LANDIS, J.R.; KOCH, G.G. The measurement of observer agreement for categorical data. Biometrics, Alexandria, v.33, n.1 (suppl.), p.159-174, Nov., 1977.

FIGURA 10 - Interpretação do Kappa

As Tabelas 1,2 e 3 representam a análise da concordância - teste Kappa

TABELA 1 - Concordância intra-examinador para o Índice de Cálculo Residual (ICR)

\begin{tabular}{|c|c|c|c|c|c|c|}
\hline & & & $1^{\circ} \mathrm{E}$ & & & \\
\hline & Escores & 0 & 1 & 2 & 3 & Total \\
\hline & 0 & 22 & 5 & 0 & 0 & 27 \\
\hline$\frac{\varepsilon}{\widetilde{్}}$ & 1 & 6 & 16 & 0 & 0 & 32 \\
\hline யీ & 2 & 0 & 3 & 3 & 0 & 6 \\
\hline & 3 & 0 & 1 & 3 & 1 & 5 \\
\hline & Total & 28 & 25 & 6 & 1 & 60 \\
\hline
\end{tabular}

k=0,56, concordância moderada - Freqüências observadas $=23-$ Freqüências causais $=14$ 
TABELA 2 - Concordância intra-examinador para o Índice de Rugosidade Superficial (IRS)

\begin{tabular}{|c|c|c|c|c|c|c|}
\hline & \multicolumn{6}{|c|}{$1^{\circ}$ Exame } \\
\hline \multirow{6}{*}{ 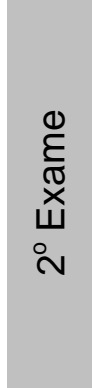 } & Escores & 0 & 1 & 2 & 3 & Total \\
\hline & 0 & 6 & 7 & 1 & 0 & 14 \\
\hline & 1 & 6 & 25 & 2 & 0 & 33 \\
\hline & 2 & 0 & 3 & 10 & 0 & 13 \\
\hline & 3 & 0 & 0 & 0 & 0 & 0 \\
\hline & Total & 12 & 35 & 13 & 0 & 60 \\
\hline
\end{tabular}

$k=0,46$, concordância moderada - Freqüências observadas $=41$ - Freqüências causais $=25$

TABELA 3 - Concordância intra-examinador para o Índice de Perda de Substância Dentária (IPSD)

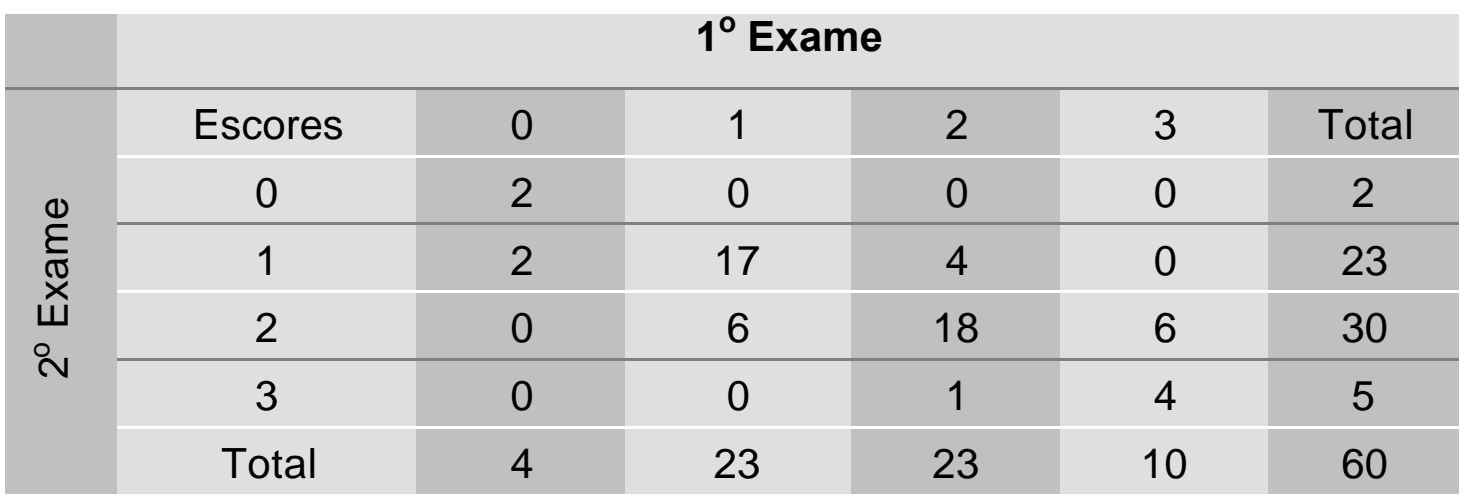

k=0,51, concordância moderada - Freqüências observadas $=41$ - Freqüências causais $=21$

Isso posto, procedeutse à obtenção dos resultados de conformidade com as variáveis selecionadas para análise, passando-se a apresentá-las por variável e por combinação de variáveis.

\subsection{Eficiência na Remoção do Cálculo (ICR)}

As medianas foram obtidas utilizando os escores das fotomicrografias nos 3 aumentos $35 \mathrm{X}, 100 \mathrm{X}$ e $350 \mathrm{X}$ associando a somatória da $1^{\circ}$ e do $2^{\circ}$ exame.

Nas Tabelas 4, 5 e 6 e na Figura 12 são apresentados os valores da análise para o ICR 
TABELA 4 - Valores de mediana, mínimo e máximo para o ICR

\begin{tabular}{|c|c|c|c|c|}
\hline Grupos & N & Mediana & Mínimo & Máximo \\
\hline ICR-1 & 10 & 1,00 & 0 & 3,0 \\
\hline ICR-2 & 10 & 2,00 & 1 & 3,0 \\
\hline ICR-3 & 10 & 1,00 & 0 & 1,5 \\
\hline ICR-4 & 10 & 0,75 & 0 & 1,0 \\
\hline ICR-5 & 10 & 2,00 & 0 & 3,0 \\
\hline ICR-6 & 10 & 0,50 & 0 & 1,0 \\
\hline
\end{tabular}

Ao realizar as comparações dos valores do ICR, foi encontrado valor de $\mathrm{KW}=28,490$ (teste de Kruskal-Wallis), significante porque a ele correspondeu um valor de $p<0,0001$. Desta forma, houve diferenças estatisticamente significativas entre os grupos experimentais quanto ao valores do ICR (Tabela 5).

TABELA 5 - Soma dos postos e postos médios para os grupos experimentais

\begin{tabular}{|c|c|c|c|}
\hline Grupos & n. & Soma dos Postos & Postos Médios \\
\hline ICR-1 & 10 & 286,0 & 28,60 \\
\hline ICR-2 & 10 & 487,5 & 48,75 \\
\hline ICR-3 & 10 & 250,5 & 25,05 \\
\hline ICR-4 & 10 & 191,5 & 19,15 \\
\hline ICR-5 & 10 & 434,5 & 43,45 \\
\hline ICR-6 & 10 & 180,0 & 18,00 \\
\hline Teste de Kruskal-Wallis - KW=28,490 (Corrigido para empates) \\
\hline
\end{tabular}

Estabelecida a existência de diferenças significantes entre os grupos, passou-se a analisar entre quais grupos apresentaram diferenças estatisticamente significantes, por meio da aplicação do teste de comparações múltiplas de Dunn, o qual se encontra expresso na Tabela 6. 
TABELA 6 - Resultados do Teste de Comparações Múltiplas de Dunn para os Grupos Experimentais

\begin{tabular}{|c|c|c|c|}
\hline Grupos & Diferenças dos Postos & Diferença & Valor de P \\
\hline ICR-1 X ICR-2 & $-20,150$ & $n s$ & $\mathrm{P}>0,05$ \\
\hline ICR-1 X ICR-3 & 3,550 & $\mathrm{~ns}$ & $\mathrm{P}>0,05$ \\
\hline ICR-1 X ICR-4 & 9,450 & $\mathrm{~ns}$ & $\mathrm{P}>0,05$ \\
\hline ICR-1 X ICR-5 & $-14,850$ & $\mathrm{~ns}$ & $\mathrm{P}>0,05$ \\
\hline ICR-1 X ICR-6 & 10,600 & $\mathrm{~ns}$ & $\mathrm{P}>0,05$ \\
\hline ICR-2 X ICR-3 & 23,700 & $*$ & $\mathrm{P}<0,05$ \\
\hline ICR-2 X ICR-4 & 29,600 & $*$ & $\mathrm{P}<0,01$ \\
\hline ICR-2 X ICR-5 & 5,300 & $\mathrm{~ns}$ & $\mathrm{P}>0,05$ \\
\hline ICR-2 X ICR-6 & 30,750 & $*$ & $\mathrm{P}<0,001$ \\
\hline ICR-3 X ICR-4 & 5,900 & $\mathrm{~ns}$ & $\mathrm{P}>0,05$ \\
\hline ICR-3 X ICR-5 & $-18,400$ & $\mathrm{~ns}$ & $\mathrm{P}>0,05$ \\
\hline ICR-3 X ICR-6 & 7,050 & $\mathrm{~ns}$ & $\mathrm{P}>0,05$ \\
\hline ICR-4 X ICR-5 & $-24,300$ & $*$ & $\mathrm{P}<0,05$ \\
\hline ICR-4 X ICR-6 & 1,150 & $\mathrm{~ns}$ & $\mathrm{P}>0,05$ \\
\hline ICR-5 X ICR-6 & 25,450 & $*$ & $\mathrm{P}<0,05$ \\
\hline ns - não significante & & & \\
\hline * significante & & & \\
\hline
\end{tabular}

A avaliação entre os seis grupos experimentais examinados, quando utilizados o ICR (Índice de Cálculo Residual) conforme escores estabelecidos e obtidas as medianas que se tornaram representativas do modelo de análise proposto. Na Tabela 6 e na Figura 12 pode-se evidenciar as diferenças estatísticas significativas entre o grupo 2 (US) em relação aos grupos 3 (US+curetas), 4 (cureta+ácido+cureta) e 6 (US+ácido+cureta). Também quando se analisou o grupo 5 (US+ácido+US) comparado com os grupos 4 (cureta+ácido+cureta) e grupo 6 (US+ácido+cureta) encontrou-se diferenças estatísticas significantes. Não houve diferenças entre os grupos 2 e 5 com relação a remoção de cálculo.

Na seqüência apresenta-se a Figura 11, a qual é representativa do ICR com seus respectivos grupos. 


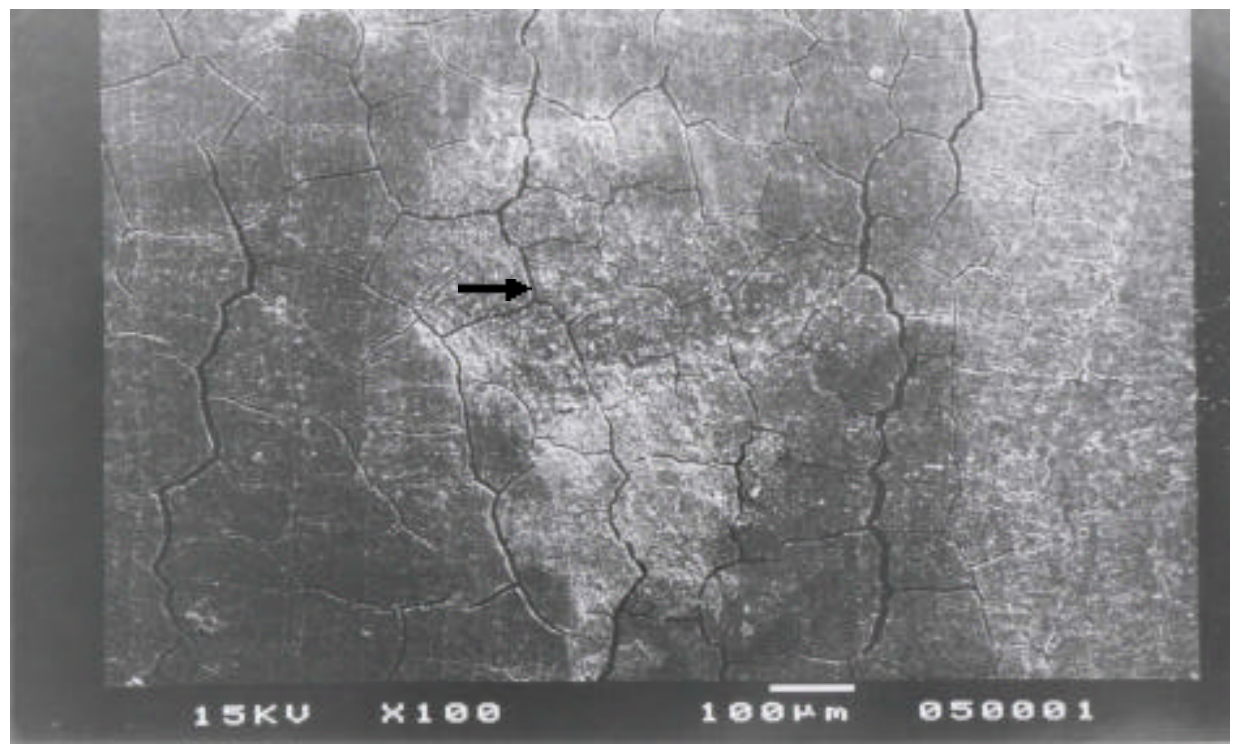

FIGURA 11 - ICR (Índice de Cálculo Residual)

FIGURA 11.A - GRUPO 1 - Vista do espécime instrumentado com cureta isoladamente demonstrando superfície radicular com algumas manchas sugerindo ser cálculo residual (vide seta), porém superfícies lisas também são encontradas Aumento100X

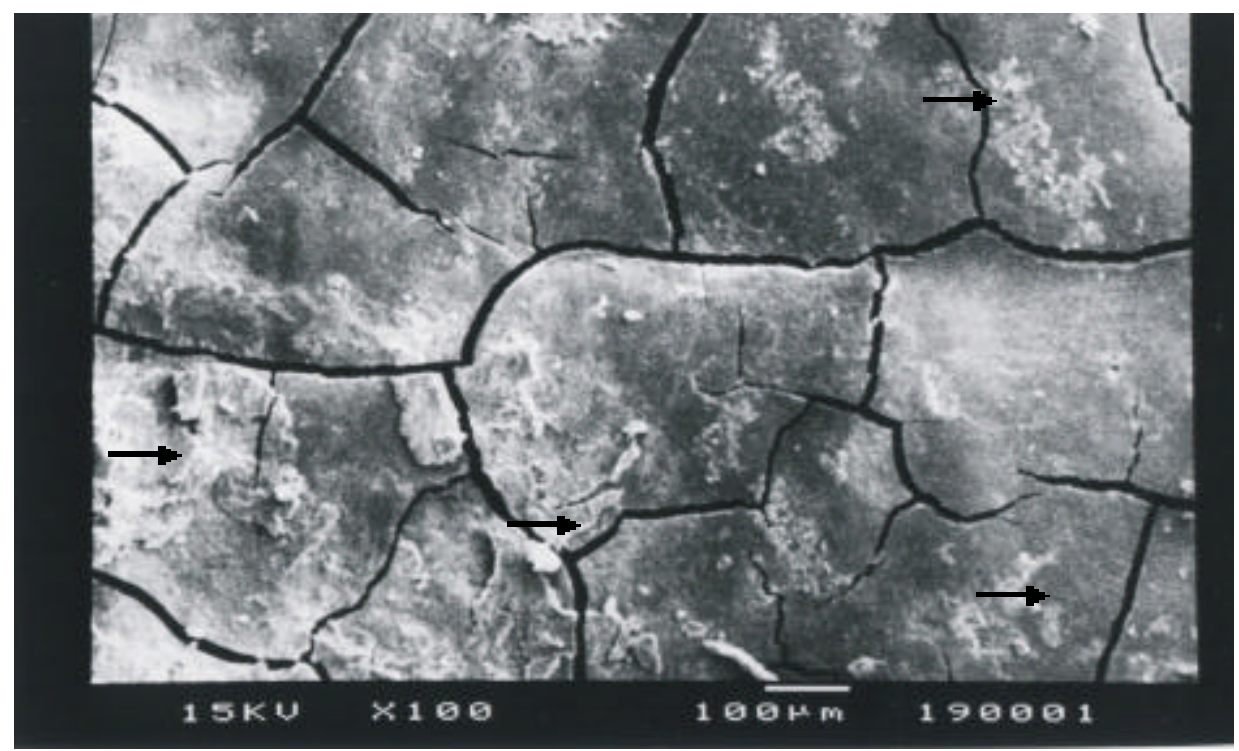

FIGURA 11.B - GRUPO 2 - Vista do espécime instrumentado com US isoladamente mostrando superfíce cementária e presença de cálculo residual (vide setas) em tamanho e quantidade razoável- Aumento 100X 


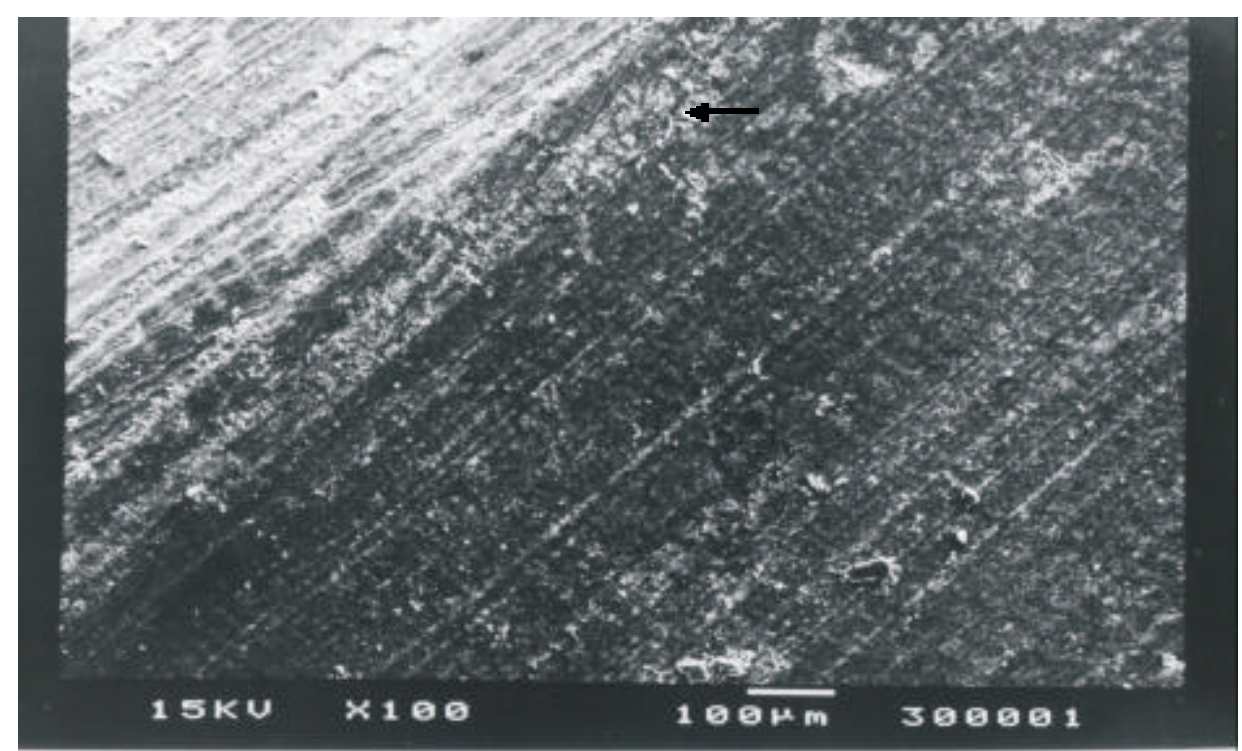

FIGURA 11.C - GRUPO 3 - Vista do espécime instrumentado com US+cureta mostrando superfície com quantidade mínima de cálculo residual - Aumento 100X

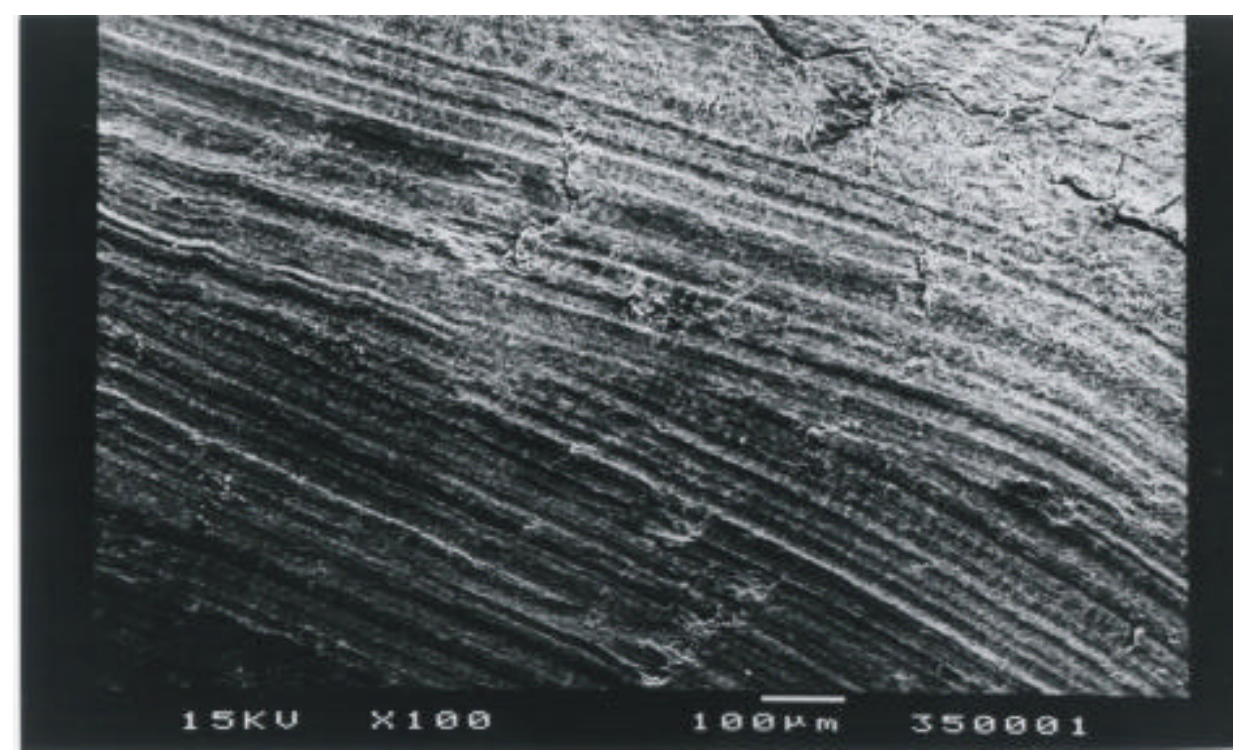

FIGURA 11.D - GRUPO 4 - Imagem ilustrando a instrumentação com cureta+ácido+cureta mostrando superfície lisa e com marcas específicas da instrumentação não denotando presença aparente de cálculo na área analisada Aumento 100X 


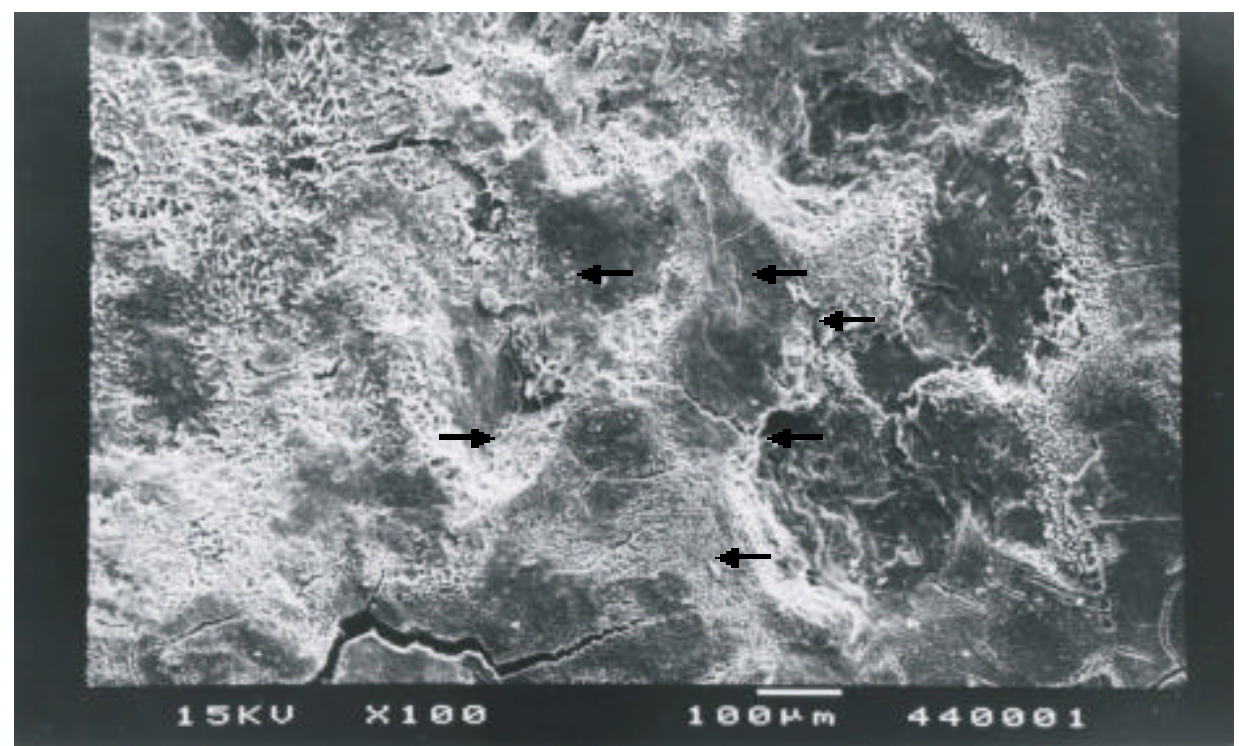

FIGURA 11.E - GRUPO 5 - Imagem ilustrando a instrumentação com US+ácido+US cuja superfície radicular apresenta quantidade razoável de cálculo aderido sobre áreas de cemento - Aumento 100X

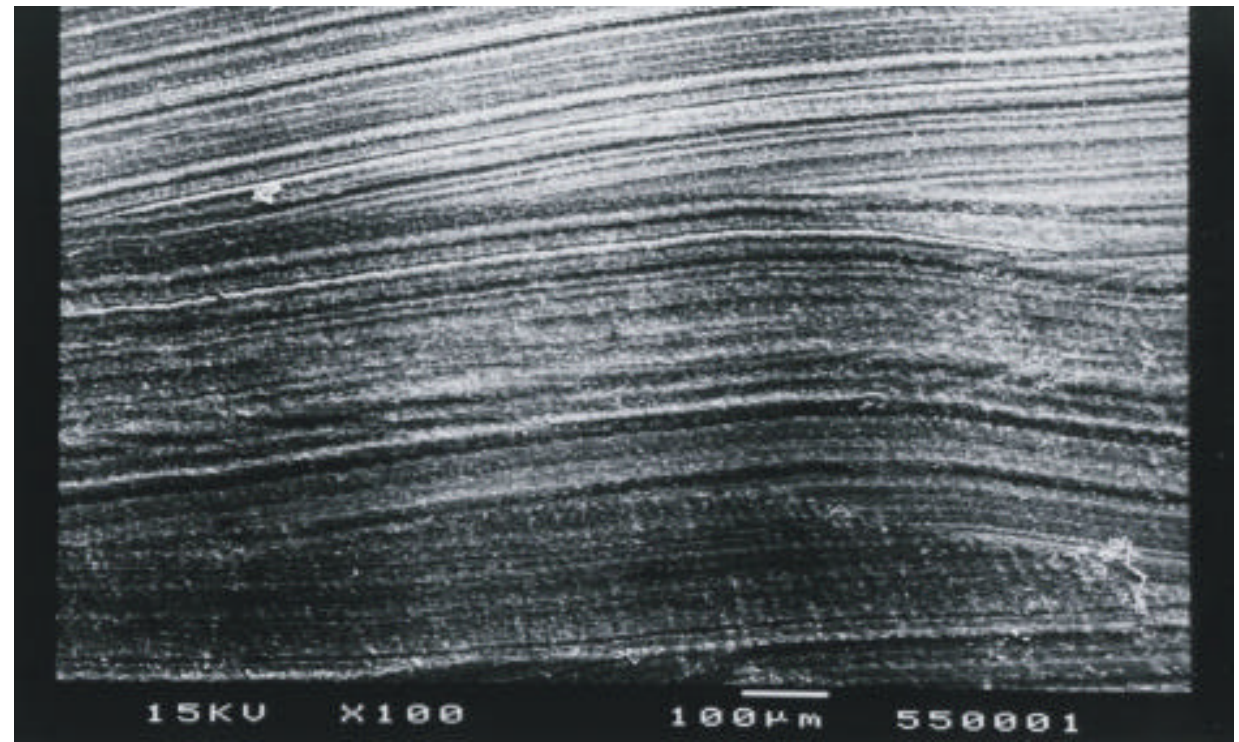

FIGURA 11.F - GRUPO 6 - Imagem ilustrando a instrumentação com US+ácido+cureta mostrando superfície lisa e uniforme não denotando presença de cálculo sobre a superfície avaliada e com marcas características da cureta na superfície radicular - Aumento 100X 


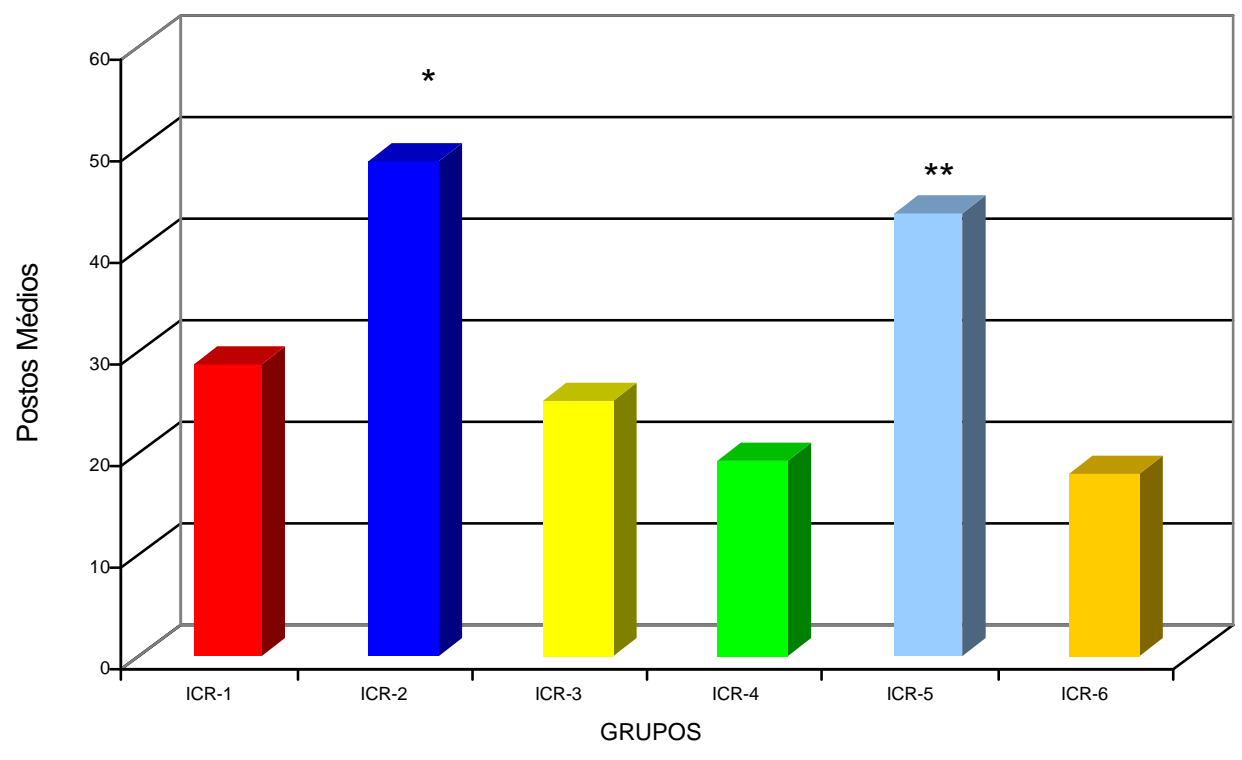

* significativo "versus" ICR-3, ICR-4 e ICR-6 - p<0,05

** significativo "versus" ICR-4 e ICR- $6-p<0,05$

FIGURA 12 - Postos médios das medianas dos escores do ICR

\subsection{Avaliação da Rugosidade Superficial (IRS)}

Quanto à análise da rugosidade da superfície radicular estão expressos nas Tabelas 7, 8 e 9 e na Figura 14 os valores da análise para o IRS.

TABELA 7 - Valores de Mediana, Mínimo e Máximo para o IRS

\begin{tabular}{|c|c|c|c|c|}
\hline Grupos & N & Mediana & Mínimo & Máximo \\
\hline IRS-1 & 10 & 1,00 & 0,0 & 2,0 \\
\hline IRS-2 & 10 & 2,25 & 1,5 & 3,0 \\
\hline IRS-3 & 10 & 1,00 & 1,0 & 2,0 \\
\hline IRS-4 & 10 & 1,00 & 0,5 & 2,0 \\
\hline IRS-5 & 10 & 2,25 & 1,0 & 3,0 \\
\hline IRS-6 & 10 & 1,00 & 0,0 & 1,5 \\
\hline
\end{tabular}

Ao realizar as comparações dos valores do IRS, foi encontrado valor de KW-30,292 (teste de Kruskal-Wallis), significante porque a ele correspondeu valor de $p<0,0001$. Desta forma, houve diferenças 
estatisticamente significativas entre os grupos experimentais quanto aos valores do IRS (Tabela 8).

TABELA 8 - Soma dos Postos e Postos Médios para os Grupos Experimentais

\begin{tabular}{|c|c|c|c|}
\hline Grupos & N & Soma dos Postos & Postos Médios \\
\hline IRS-1 & 10 & 194,0 & 19,40 \\
\hline IRS-2 & 10 & 485,5 & 48,50 \\
\hline IRS-3 & 10 & 275,5 & 27,50 \\
\hline IRS-4 & 10 & 245,5 & 24,55 \\
\hline IRS-5 & 10 & 445,0 & 44,50 \\
\hline IRS-6 & 10 & 184,5 & 18,45 \\
\hline
\end{tabular}

Analogamente ao índice anterior, para localizar os grupos que apresentam diferenças estatisticamente significantes, foi realizado o teste de comparações múltiplas de Dunn, o qual se encontra expresso na Tabela 9. 
TABELA 9 - Resultados do Teste de Comparações Múltiplos de Dunn para os Grupos Experimentais

\begin{tabular}{|c|c|c|c|}
\hline Grupos & Diferenças dos Postos & Diferença & Valor de P \\
\hline IRS-1 X IRS-2 & $-29,15$ & $*$ & $\mathrm{P}<0,01$ \\
\hline IRS-1 X IRS-3 & $-8,15$ & Ns & $\mathrm{P}>0,05$ \\
\hline IRS-1 X IRS-4 & $-5,15$ & Ns & $\mathrm{P}>0,05$ \\
\hline IRS-1 X IRS-5 & $-25,10$ & $*$ & $\mathrm{P}<0,05$ \\
\hline IRS-1 X IRS-6 & 0,95 & Ns & $\mathrm{P}>0,05$ \\
\hline IRS-2 X IRS-3 & 21,00 & Ns & $\mathrm{P}>0,05$ \\
\hline IRS-2 X IRS-4 & 24,00 & $*$ & $\mathrm{P}<0,05$ \\
\hline IRS-2 X IRS-5 & 4,05 & Ns & $\mathrm{P}>0,05$ \\
\hline IRS-2 X IRS-6 & 30,10 & $*$ & $\mathrm{P}<0,001$ \\
\hline IRS-3 X IRS-4 & 3,00 & Ns & $\mathrm{P}>0,05$ \\
\hline IRS-3 X IRS-5 & $-16,95$ & Ns & $\mathrm{P}>0,05$ \\
\hline IRS-3 X IRS-6 & 9,10 & Ns & $\mathrm{P}>0,05$ \\
\hline IRS-4 X IRS-5 & $-19,50$ & Ns & $\mathrm{P}>0,05$ \\
\hline IRS-4 X IRS-6 & 6,10 & Ns & $\mathrm{P}>0,05$ \\
\hline IRS-5 X IRS-6 & 26,05 & $*$ & $\mathrm{P}<0,05$ \\
\hline ns - não significante & & & \\
\hline - significante & & & \\
\hline
\end{tabular}

As avaliações com relação ao IRS (Índice da Rugosidade Superficial) demonstraram diferenças estatísticas significantes quando comparado ao grupo 2 (US) em relação aos grupos 1 (cureta), 4 (cureta+ácido+cureta) e 6 (US+ácido+cureta). O grupo 5 (US+ácido+US) também demonstrou diferenças significativas quando relacionados com os grupos 1 (cureta) e 6 (US+ácido+cureta).

Na seqüência apresenta-se a Figura 13, a qual é representativa do IRS com seus respectivos grupos. 


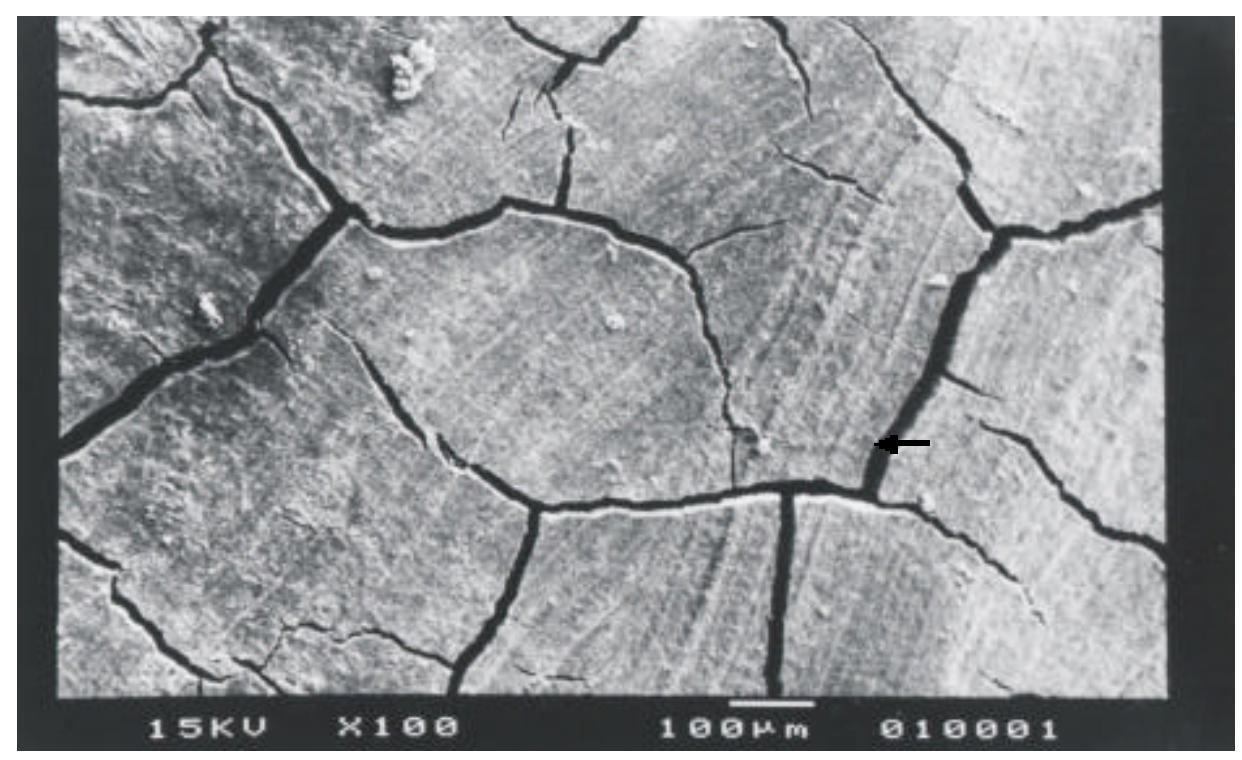

FIGURA 13 - IRS (Índice de Rugosidade de Superfície)

FIGURA 13.A - GRUPO 1 - Vista da instrumentação com cureta isoladamente sobre a superfície radicular mostrando superfície lisa e uniforme. $O$ aspecto de fraturas na superfície (vide seta) é devido a desidratação do fragmento quando do preparo do fragmento para análise em MEV - Aumento 100X

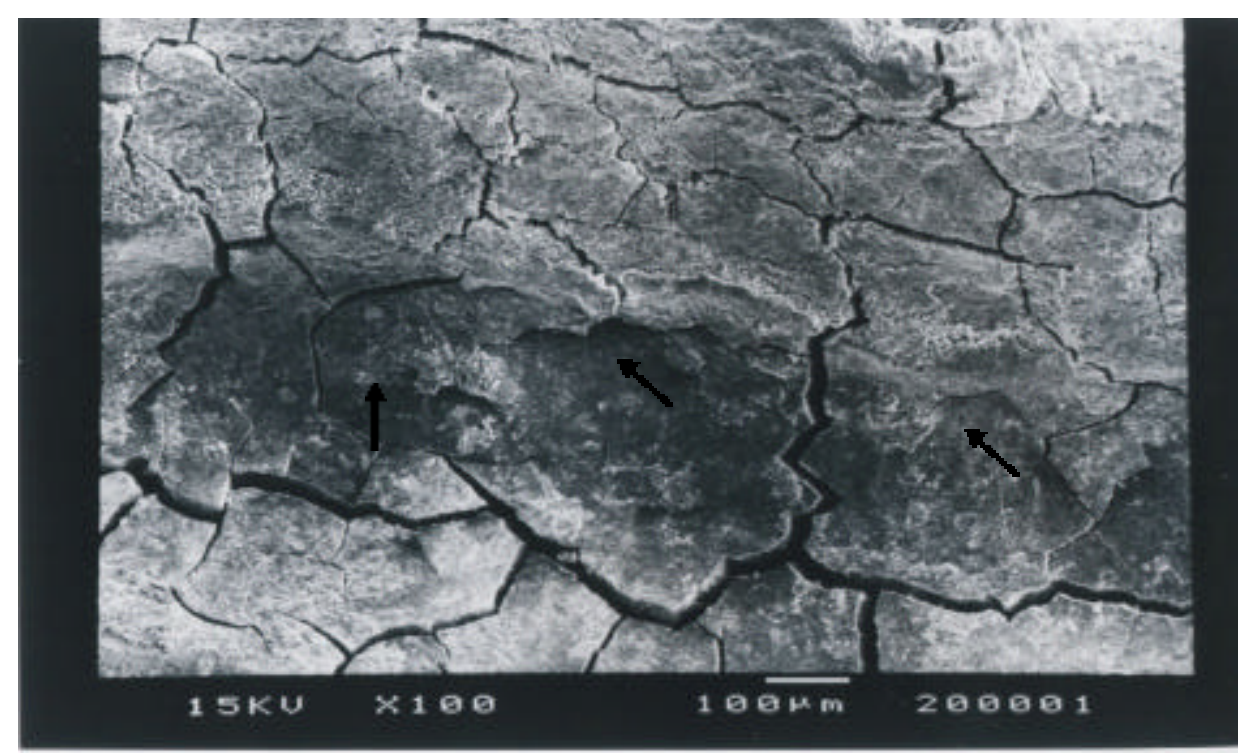

FIGURA 13.B - GRUPO 2 - Vista da instrumentação com US isoladamente ilustrando superfície radicular bastante irregular com depressões (vide setas) formadas pelo instrumento e com características rugosas - Aumento 100X 


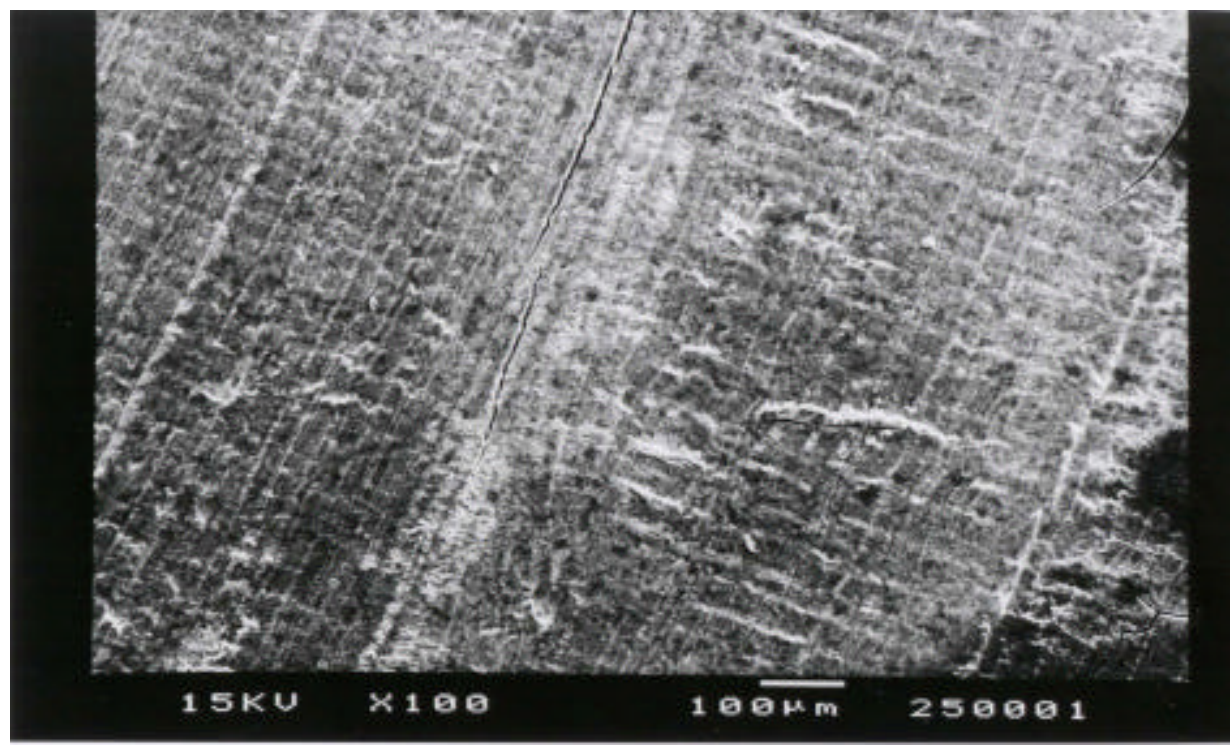

FIGURA 13.C - GRUPO 3 - Vista da instrumentação com US+cureta mostrando superfície lisa e aparentemente uniforme, porém com algumas áreas rugosas (vide setas) - Aumento $100 \mathrm{X}$

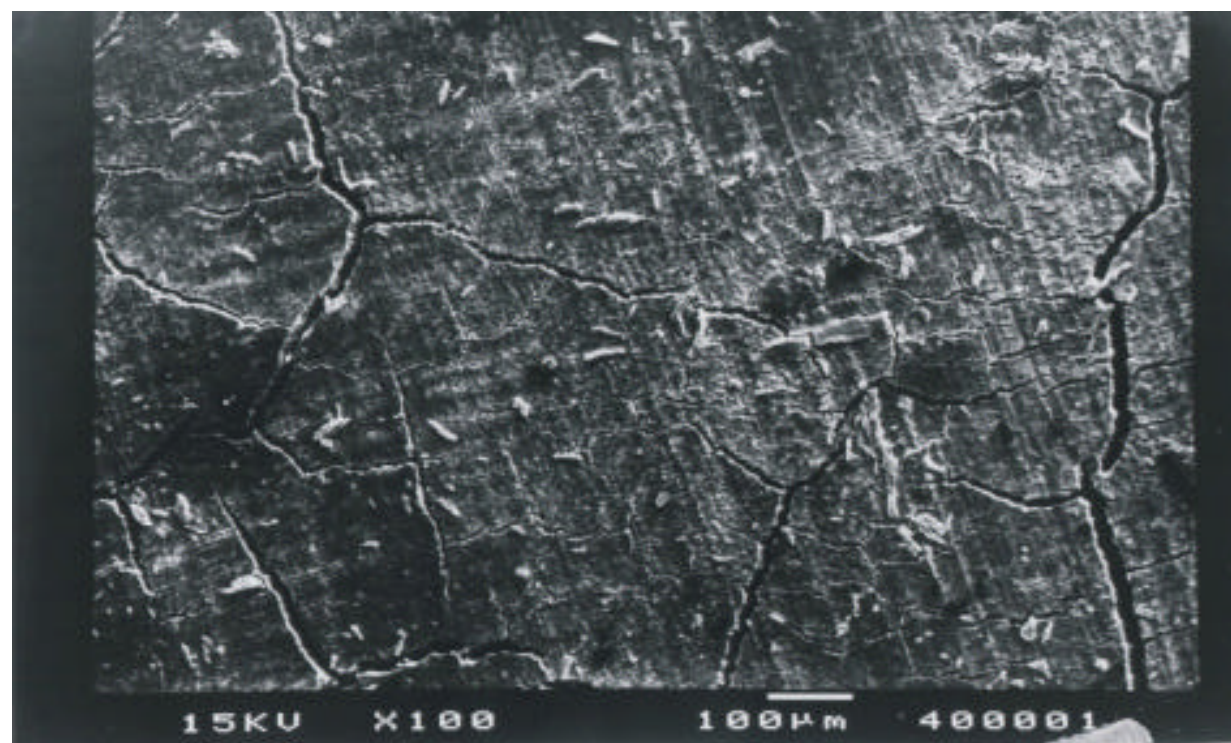

FIGURA 13.D - GRUPO 4 - Vista da instrumentação com cureta+ácido+cureta mostrando superfície lisa com certa uniformidade e com pouca rugosidade - Aumento $100 \mathrm{X}$ 


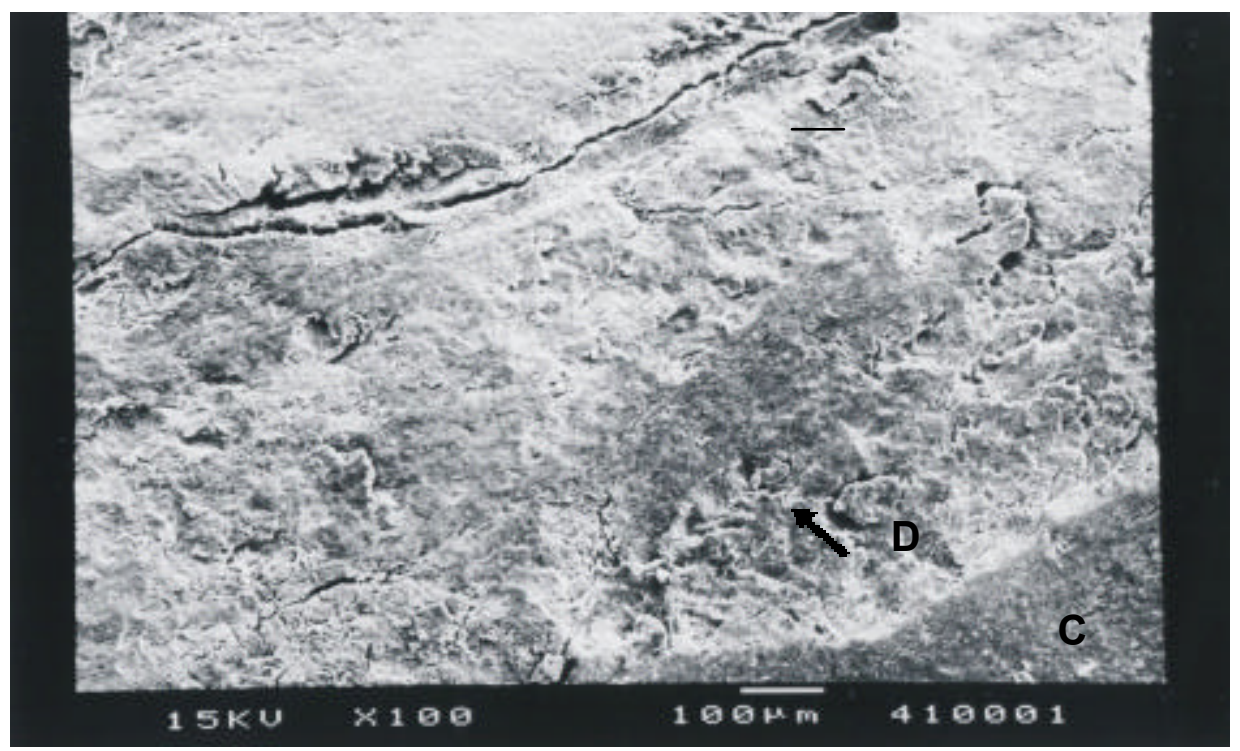

FIGURA 13.E - GRUPO 5 - Vista da instrumentação com US+ácido+US mostrando superfície bastante rugosa de cemento (C) e com presença de dentina exposta bastante rugosa (vide seta) - Aumento $100 \mathrm{X}$

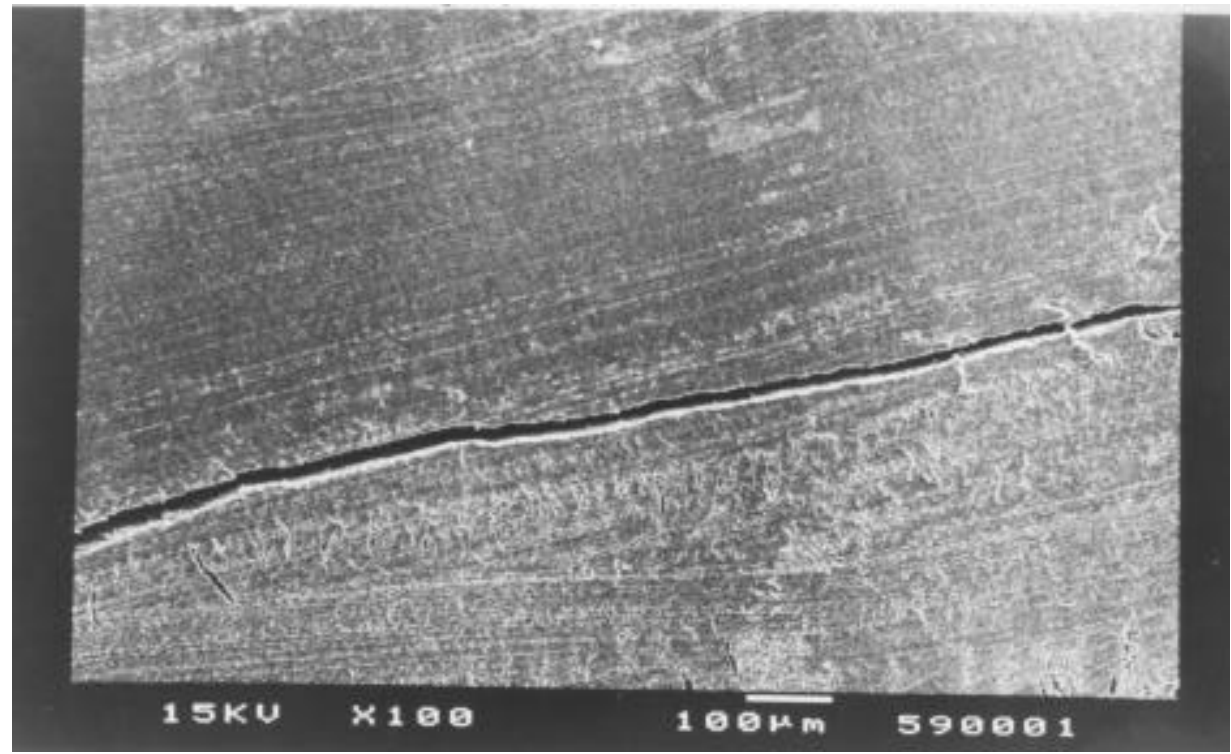

FIGURA 13.F - GRUPO 6 - Vista da instrumentação com US+ácido+cureta mostrando superfície radicular lisa e uniforme - Aumento $100 \mathrm{X}$ 


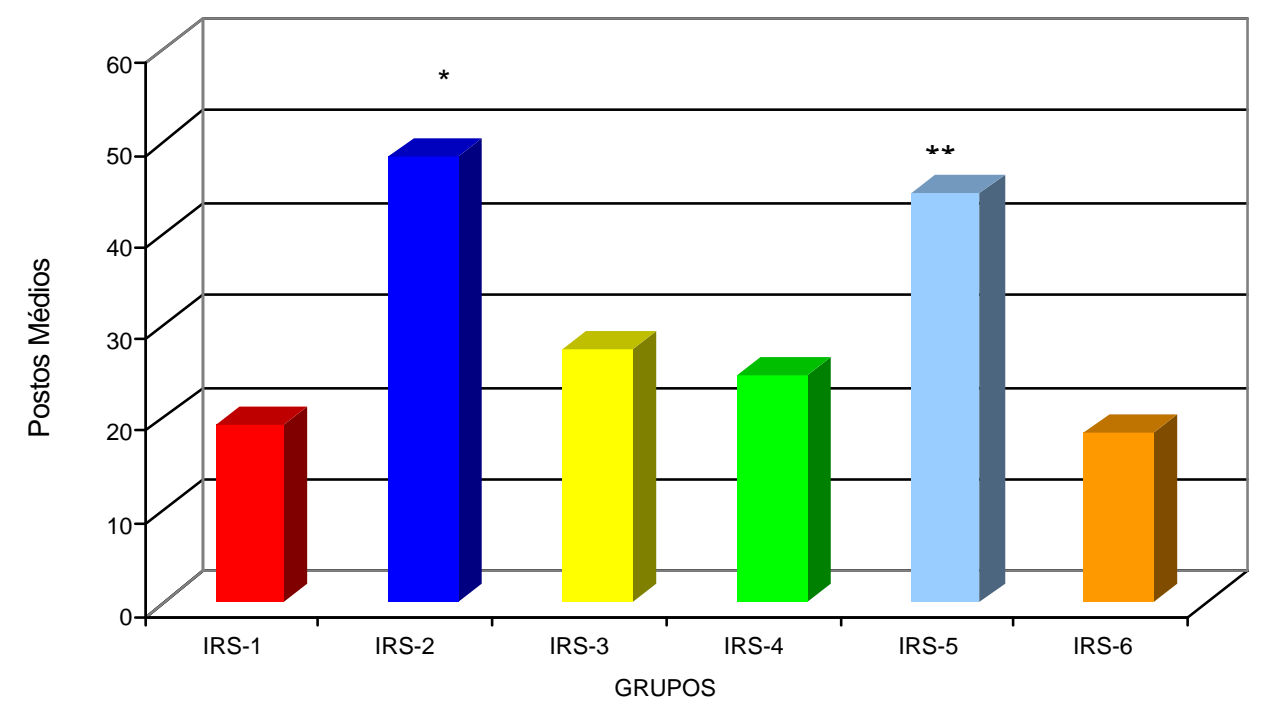

* significativo "versus" IRS -1, IRS -4 e IRS6 - p<0,05

** sianificativo "versus" IRS-1 e IRS- $6-\mathrm{D}<0.05$

FIGURA 14 - Postos Médios das Medianas dos Escores do IRS

\subsection{Avaliação da Perda de Substância Dentária (IPSD)}

Nas Tabelas 10 e 11 e na Figura 16 são apresentados os valores da análise para o IPSD.

TABELA 10 - Valores de Mediana, Mínimo e Máximo para o IPSD

\begin{tabular}{|c|c|c|c|c|}
\hline Grupos & N & Mediana & Mínimo & Máximo \\
\hline IPSD-1 & 10 & 1,5 & 1,0 & 2,5 \\
\hline IPSD-2 & 10 & 1,0 & 0,5 & 3,0 \\
\hline IPSD-3 & 10 & 2,0 & 1,0 & 3,0 \\
\hline IPSD-4 & 10 & 2,0 & 1,0 & 2,5 \\
\hline IPSD-5 & 10 & 1,0 & 0,0 & 3,0 \\
\hline IPSD-6 & 10 & 2,0 & 0,0 & 3,0 \\
\hline
\end{tabular}

Ao realizar as comparações dos valores do IPSD, foi encontrado valor de $\mathrm{KW}=7,298$ (teste de Kruskal-Wallis), considerado não significante porque a ele correspondeu valor de $p=0,1994$. Desta forma, não houve diferenças 
estatisticamente significativas entre os grupos experimentais quanto aos valores do IPSD (Tabela 11).

TABELA 11 - Soma dos Postos e Postos Médios para os Grupos Experimentais

\begin{tabular}{|c|c|c|c|}
\hline Grupos & n. & Soma dos Postos & Postos Médios \\
\hline IPSD-1 & 10 & 281,5 & 28,15 \\
\hline IPSD-2 & 10 & 283,5 & 28,35 \\
\hline IPSD-3 & 10 & 346,0 & 34,60 \\
\hline IPSD-4 & 10 & 388,0 & 38,80 \\
\hline IPSD-5 & 10 & 202,5 & 20,25 \\
\hline IPSD-6 & 10 & 328,5 & 32,85 \\
\hline \multicolumn{2}{l}{ Teste de Kruskal-Wallis - KW=7,298 (Corrigido para empates) } \\
\hline
\end{tabular}

Com relação a perda de substância dentária não houve diferenças estatísticas significativas entre os seis grupos examinados.

Na seqüência apresenta-se a Figura 15, a qual é representativa do IPSD com seus respectivos grupos. 


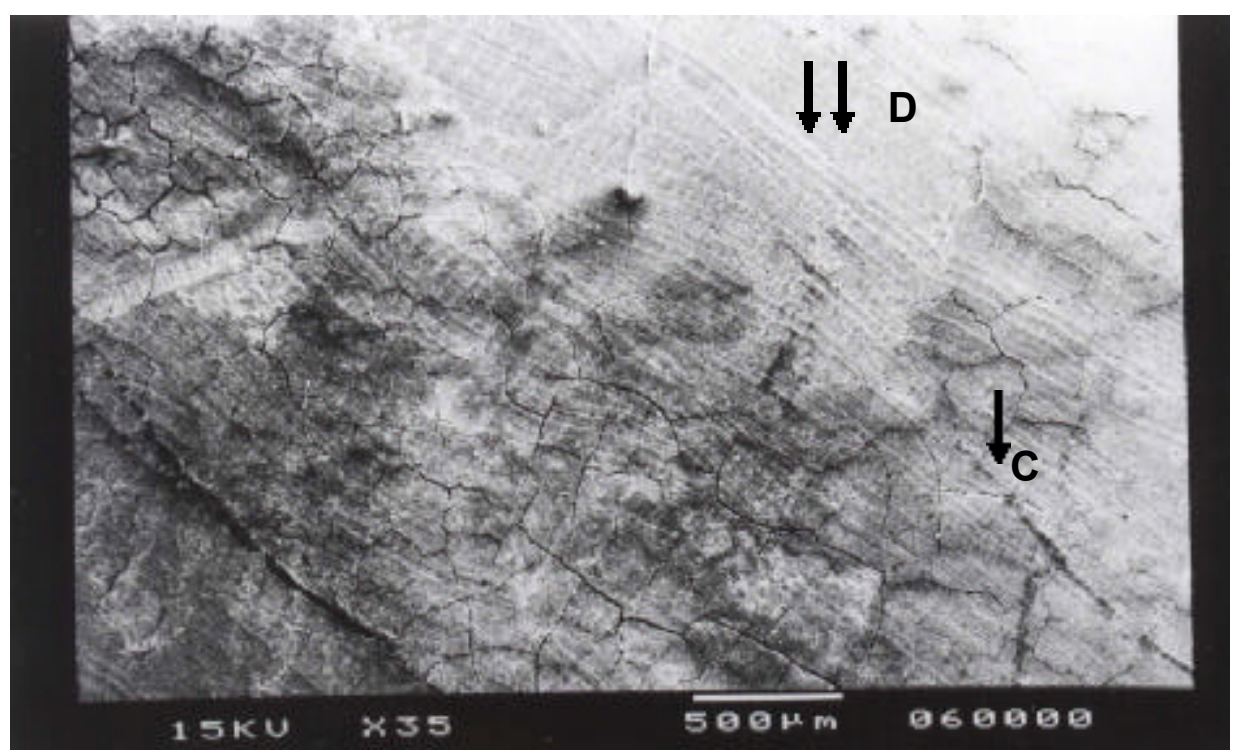

FIGURA 15 - IPSD (Índice de Perda da Substância Dentária)

FIGURA 15.A - GRUPO 1 - Vista da instrumentação com cureta isoladamente mostrando camada de cemento (C) (vide seta simples) e camada de dentina (D) (vide seta dupla) Aumento 35X

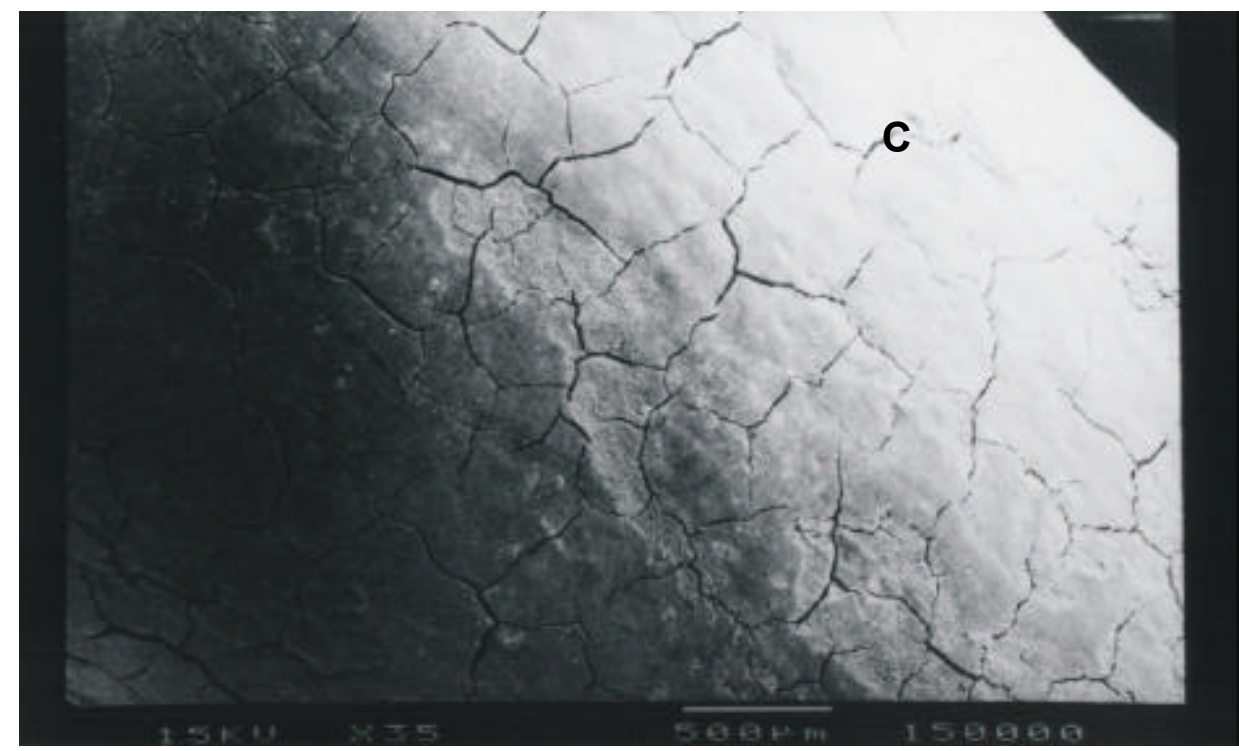

FIGURA 15.B - GRUPO 2 - Vista da instrumentação com US isoladamente mostrando grande quantidade de cemento (C) sem camada de dentina exposta- Aumento 35X 


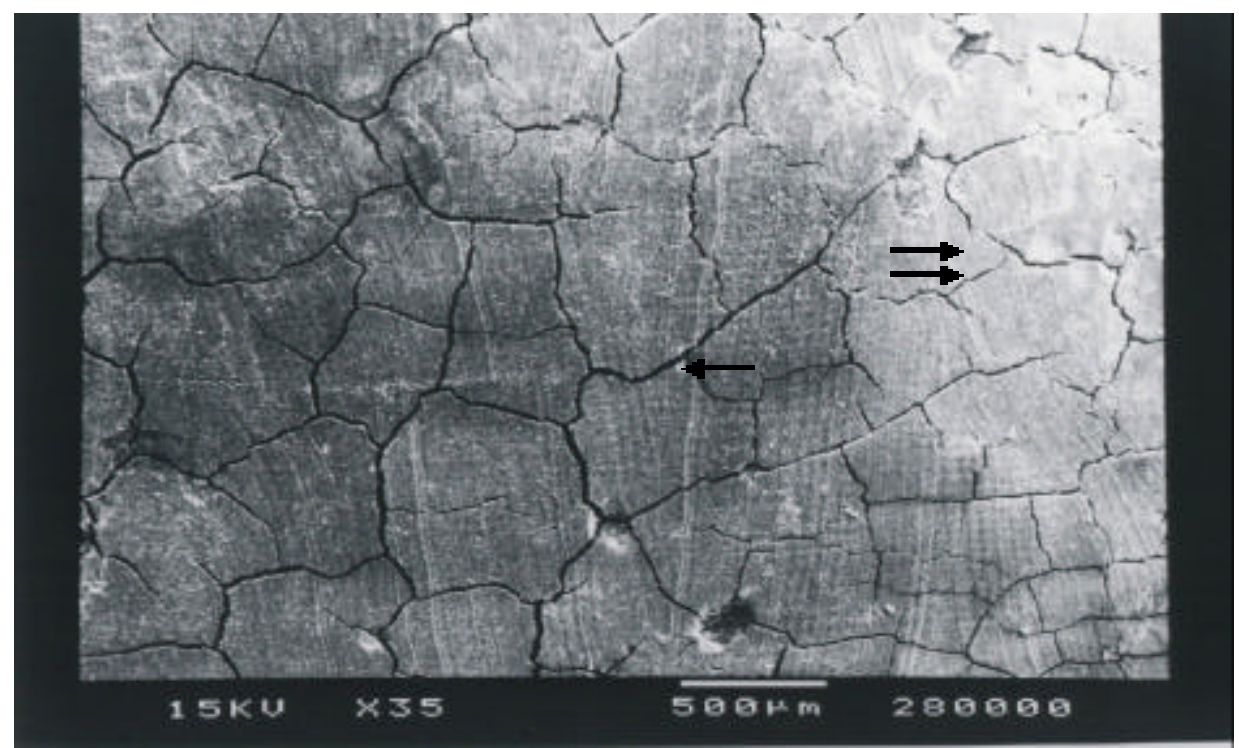

FIGURA 15.C - GRUPO 3 - Vista da instrumentação com US+cureta mostrando superfície com marcas da cureta ( vide seta) porém com cemento em boa quantidade e algumas áreas de dentina exposta (Vide seta dupla) - Aumento 35X

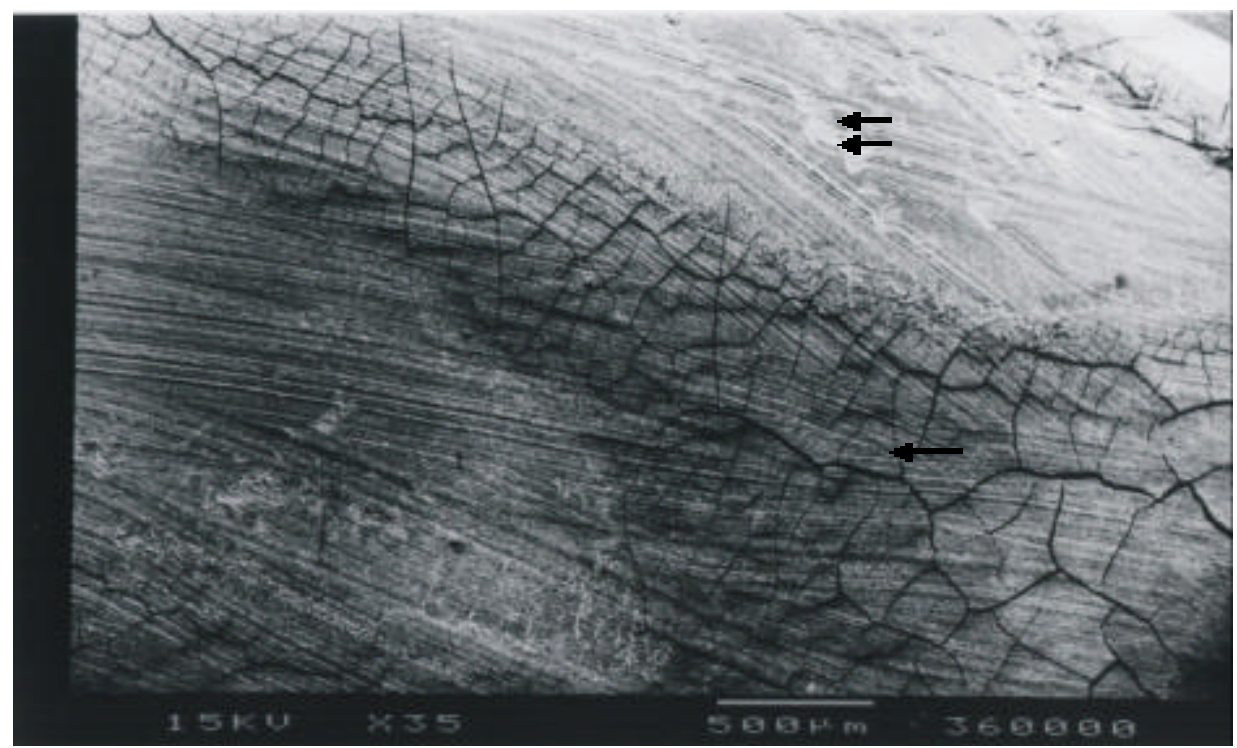

FIGURA 15.D - GRUPO 4 - Vista da instrumentação com cureta+ácido +cureta mostrando superfície com cemento (vide seta simples) e dentina exposta com marcas evidentes do instrumento utilizado (Vide seta dupla) - Aumento 35X 


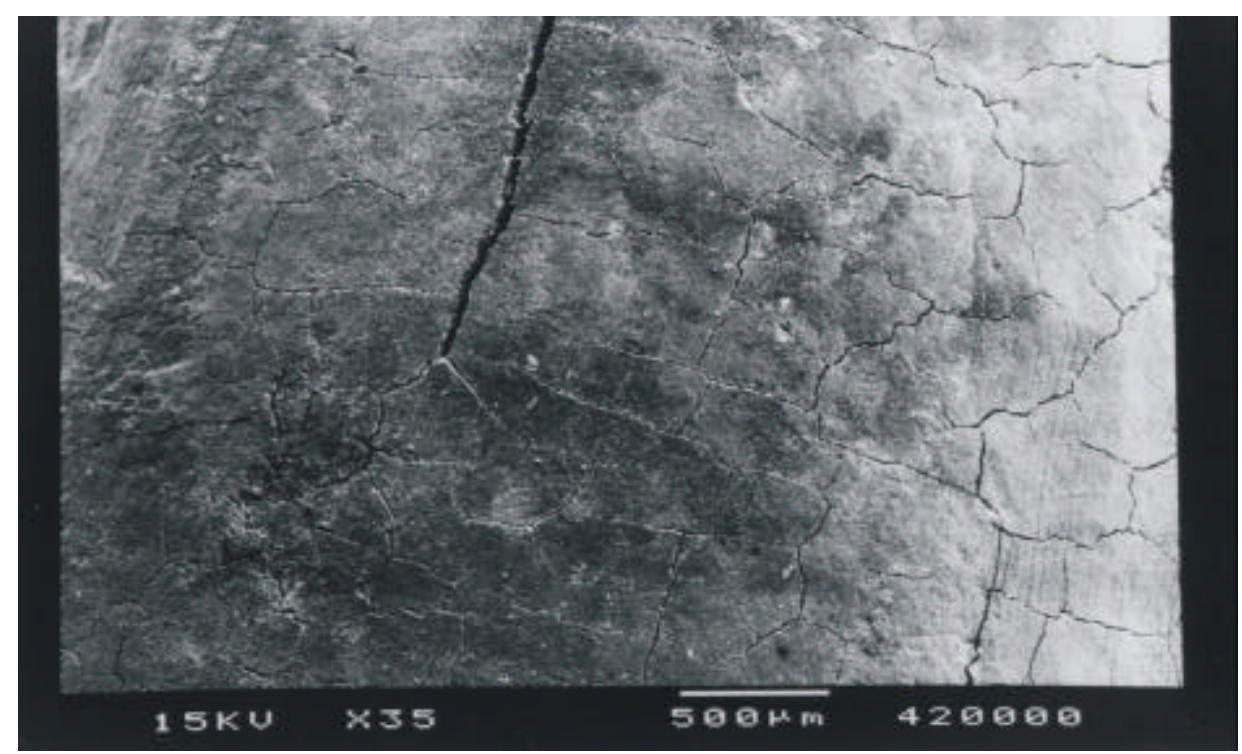

FIGURA 15.E - GRUPO 5 - Vista da instrumentação com US+ácido+US mostrando superfície com cemento em boa quantidade sem visualização de dentina exposta - Aumento 35X

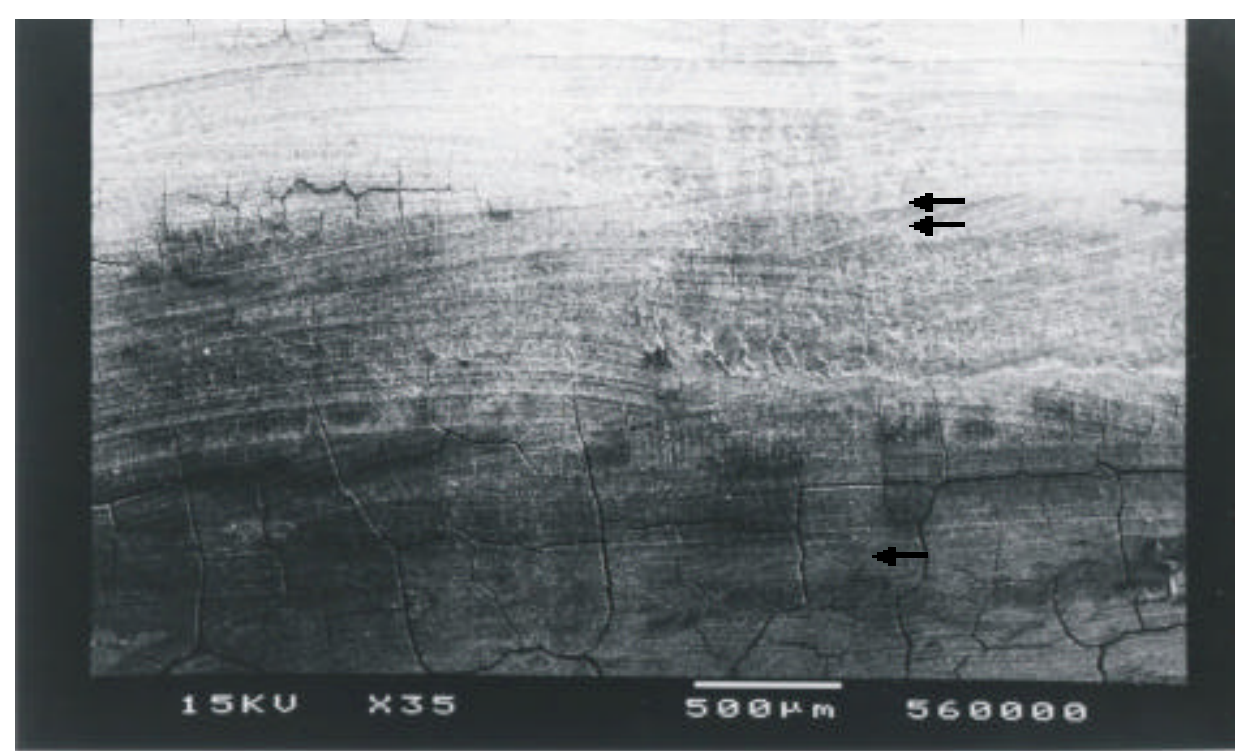

FIGURA 15.F - GRUPO 6 - Vista da instrumentação com US+ácido+cureta mostrando superfície com cemento (vide seta simples) e dentina exposta (vide seta dupla) - Aumento 35X 


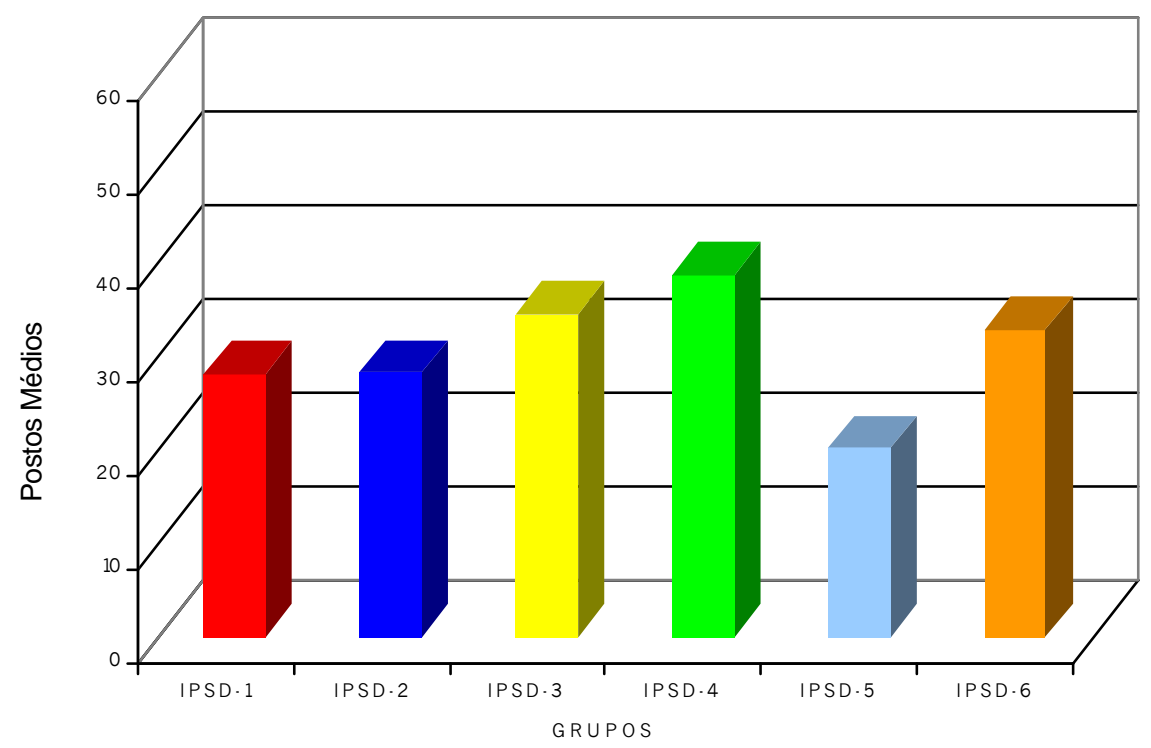

Diferenças não significativas $-p=0,1994(p>0,05)$

FIGURA 16 - Postos Médios das Medianas dos Escores do IPSD

\subsection{Correlação entre os índices ICR, IRS e IPSD}

Nas Figuras 17, 18 e 20 são apresentados os valores da correlação entre ICR e IRS, ICR e IPSD e IRS e IPSD, utilizando a análise estatística não paramétrica de Spearman.

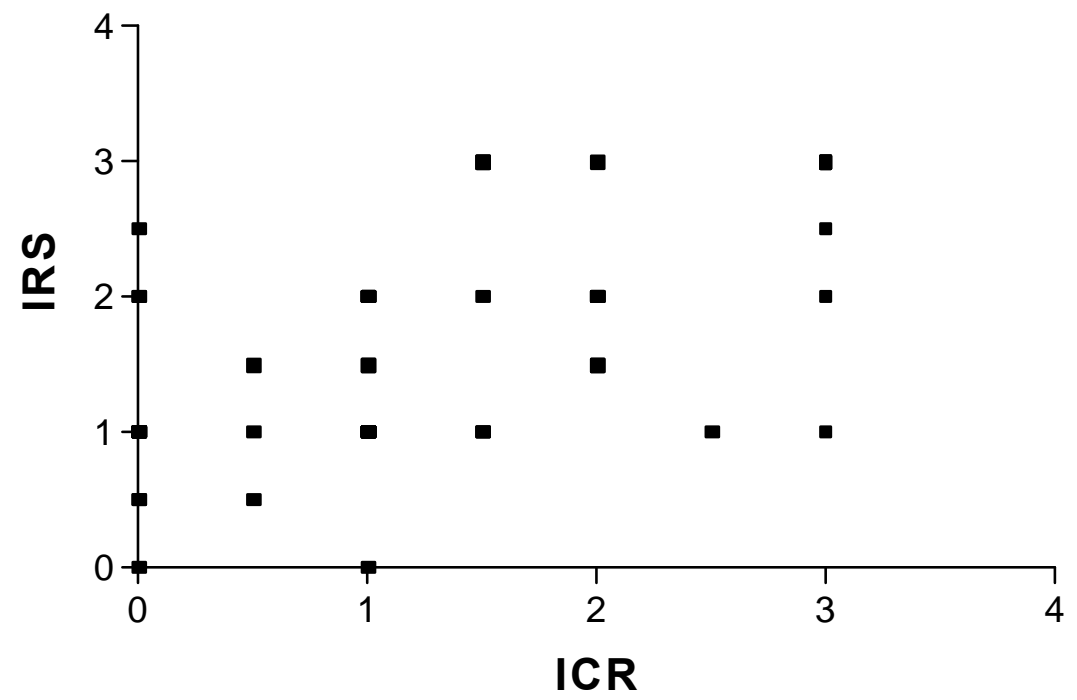

$r=0,5491$, sendo $p<0,0001$ - considerado significativa $(p<0,05)$

FIGURA 17 - Correlação entre os Valores das Medianas dos Escores do ICR e IRS 
Quando se analisa a comparação entre os índices utilizados para avaliação dos vários tipos de instrumentação na superfície radicular, o ICR (Índice de cálculo residual) X IRS (Índice de rugosidade superficial) mostraram-se extremamente significantes $\mathrm{P}<0.0001$ (Vide Figuras 11.B p. 58. e 11.F p. 60).

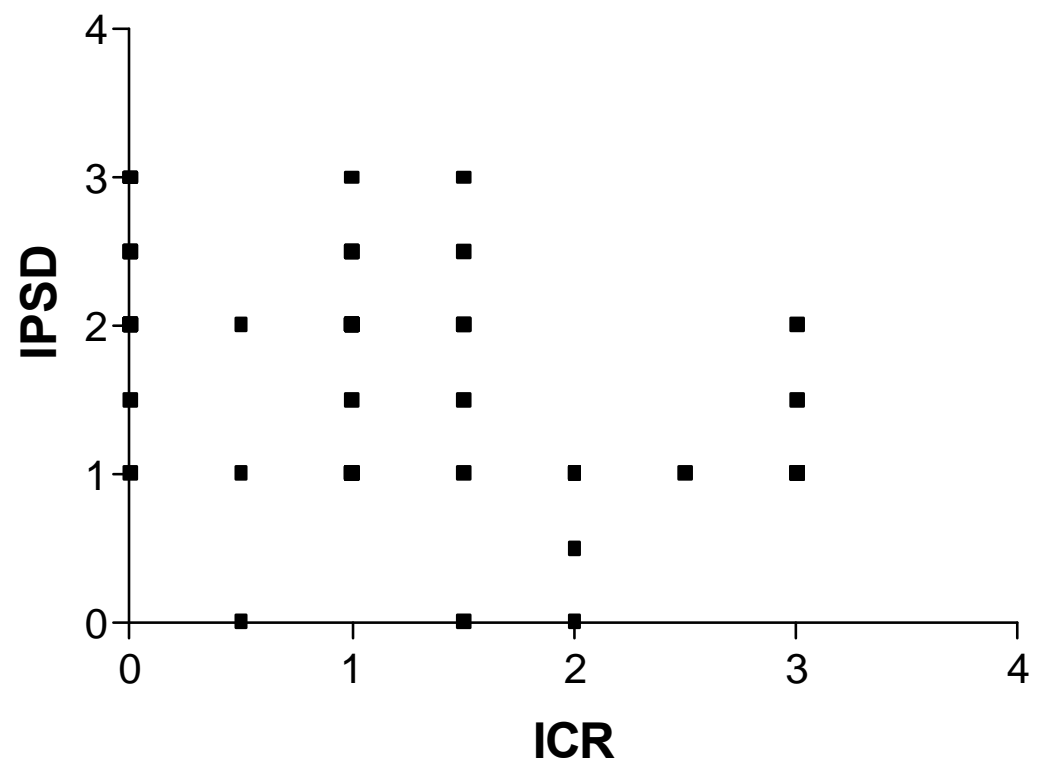

$r=-0,5114$, sendo $p<0,0001-$ considerado significativa $(p<0,05)$

FIGURA 18 - Correlação entre os Valores das Medianas dos Escores do ICR e IPSD

Quando se analisa a comparação entre os índices utilizados para avaliação dos vários tipos de instrumentação na superfície radicular, o ICR (Índice de cálculo residual) X IPSD (Índice de perda de substância dentária) mostraram-se extremamente significantes $P<0.0001$ (Figuras 13.F p. 66 e 19 a seguir). 


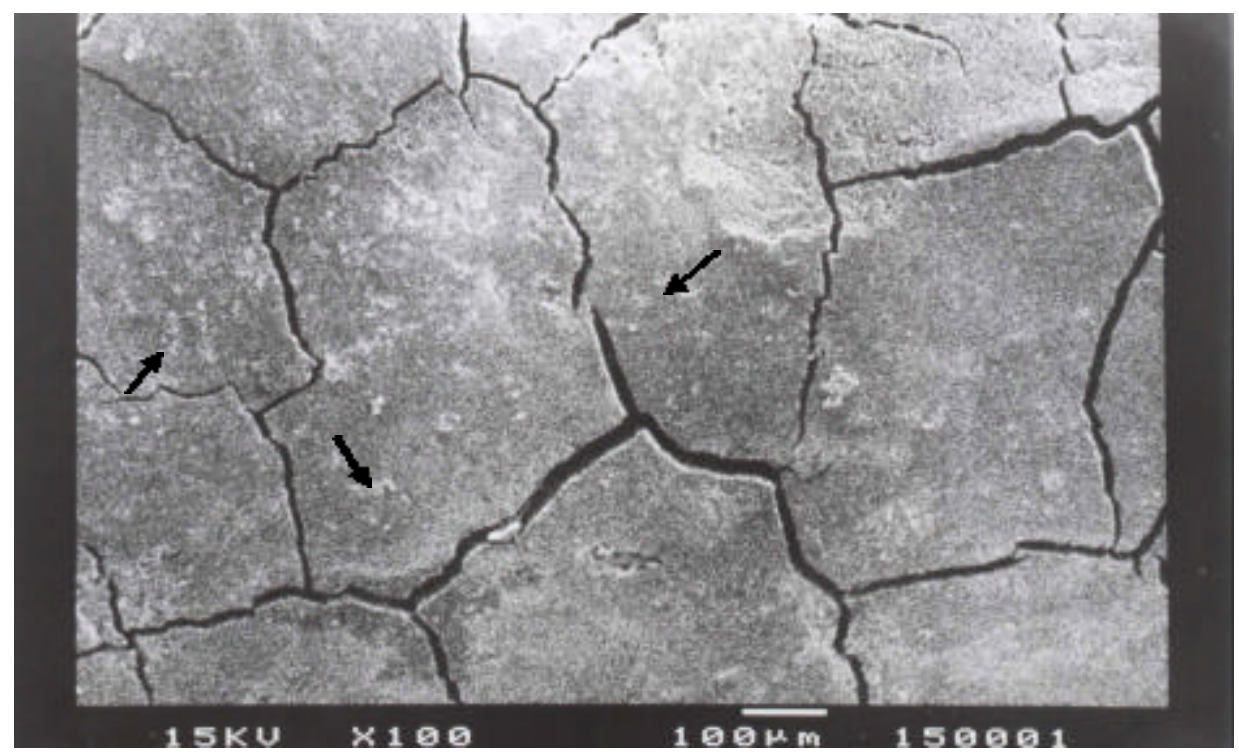

FIGURA 19 - Vista da instrumentação com US isoladamente denotando presença de cálculo (vide setas) o qual demonstra a pouca perda de substância dentária - Aumento 100X

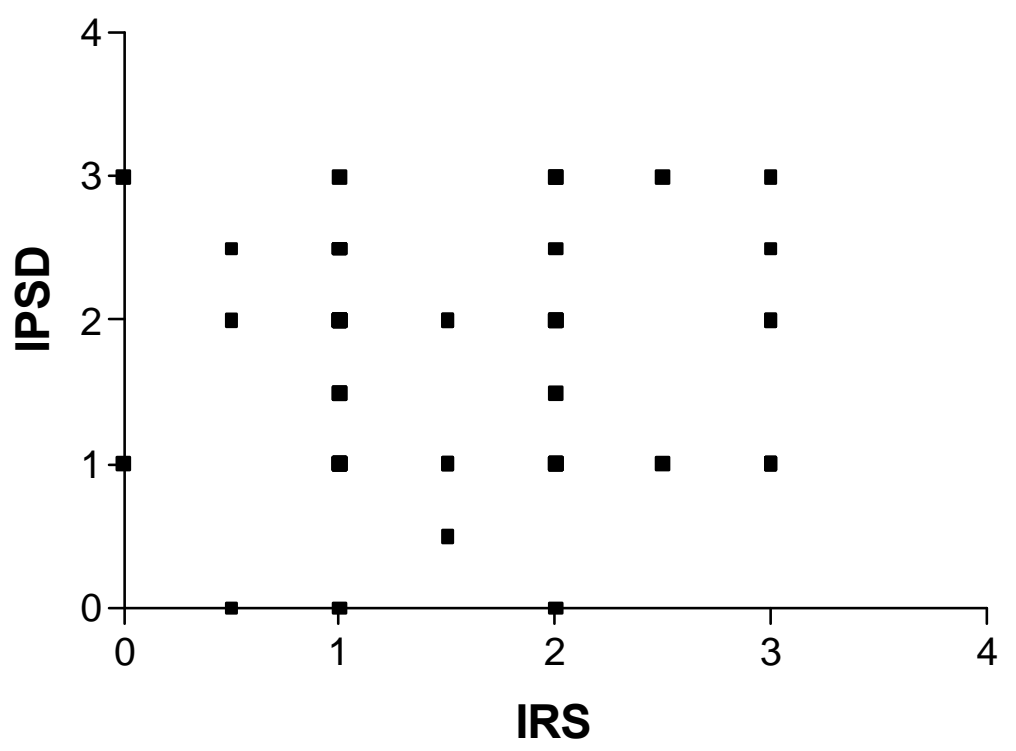

$r=-0,0282$, sendo $p=0,8305$ - considerado não significativa $(p>0,05)$

FIGURA 20 - Correlação entre os Valores das Medianas dos Escores do IRS e IPSD

Quando se analisa a comparação entre os índices utilizados para avaliação dos vários tipos de instrumentação na superfície radicular, o IRS (Índice de rugosidade superficial) X IPSD (Índice de perda de substância dentária) mostraram-se não significantes $\mathrm{P}=0,8305$, demonstrando que não há correlação entre as variáveis (Figuras 21.A e 21.B) 
FIGURA 21 - Comparação entre IRS e IPSD

LEGENDA: Figuras 22.A e 21.B - Superfícies demonstrando grande quantidade de perda de substância, porém com dentina exposta e marcas bem características na mesma (vide setas) denotando presença de rugosidade bem evidente - Aumento 35X $35 \mathrm{~A}$ e 100X 35B

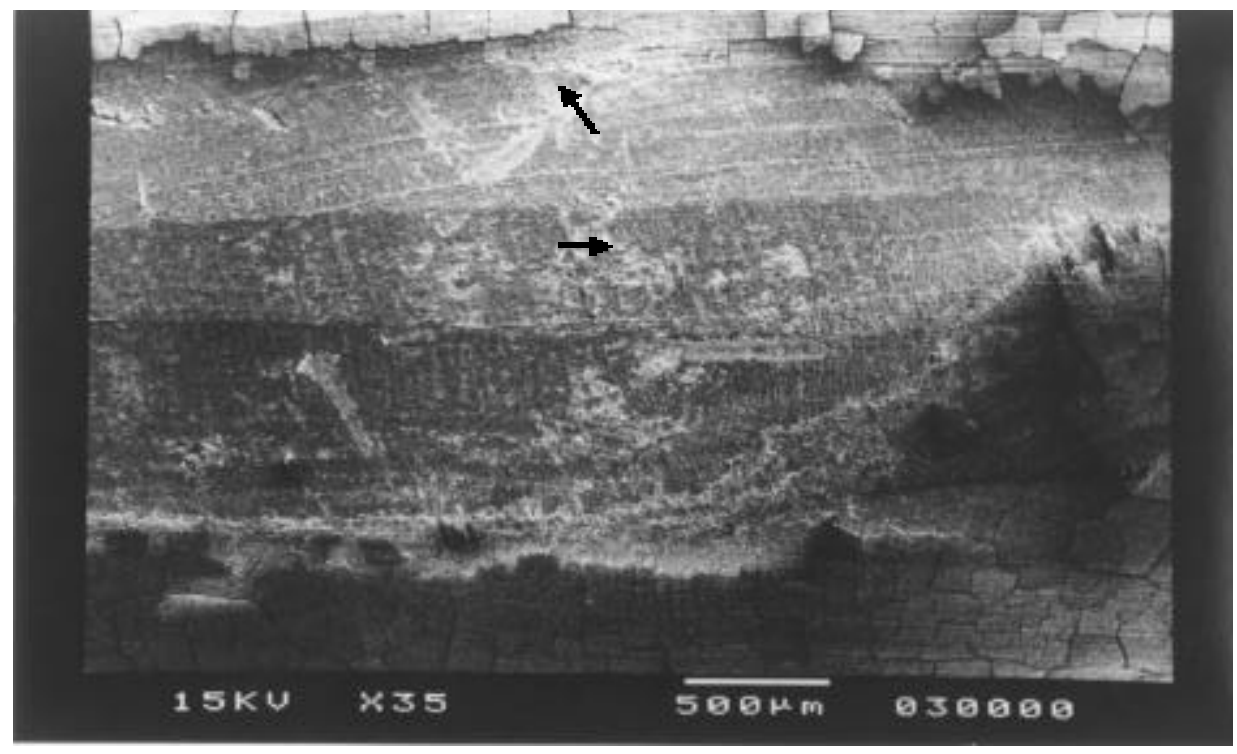

Figura 21.A - Imagem ilustrativa demonstrando marcas da instrumentação em dentina - aumento $35 \mathrm{X}$

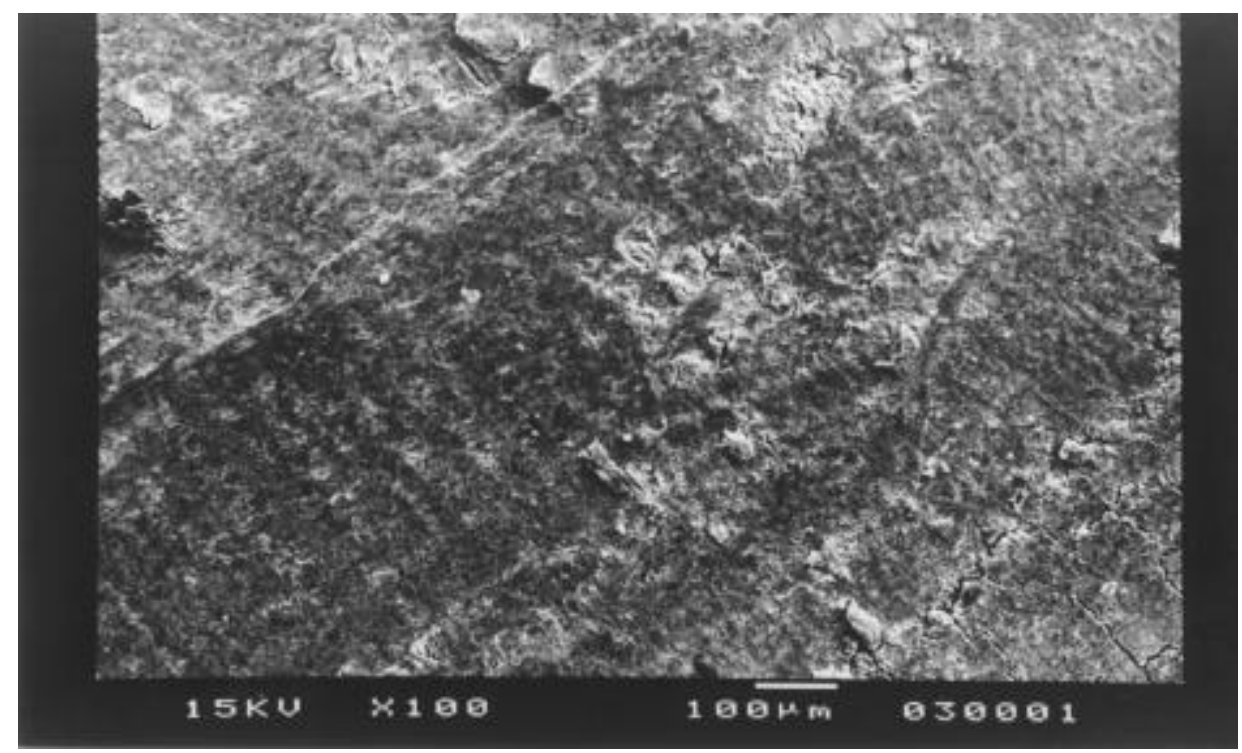

Figura 21.B - Imagem ilustrativa demonstrando em aumento de 100X rugosidades em dentina 


\section{DISCUSSÃO}

A preservação da saúde bucal, e em particular da saúde periodontal, é, sem dúvida nenhuma, de fundamental importância para a saúde geral do paciente, que representa uma unidade biológica e como tal deve ser tratado e respeitado.

A pura e simples introdução recente da chamada Medicina Periodontal parece demonstrar o valor e alcance de tais considerações.

Nesse contexto, assumem relevância tanto as medidas preventivas na sua essência, como também as medidas terapêuticas, que visam propiciar as condições adequadas para a aplicação de medidas preventivas ainda que em níveis mais avançados, porém em condições de fazer prevalecer o bem estar físico, social e moral do paciente, levando-o à plenitude de suas realizações.

Nessas circunstâncias todo e qualquer fator que contribua para o alcance desses objetivos tem que merecer a melhor das atenções para o bom atendimento do ser humano.

Assim há que se ver na Periodontia a ciência que cuida de prover as condições necessárias e mínimas para que o paciente possa ter 0 restabelecimento e/ou manter a higiene bucal em nível compatível com a manifestação dos processos homeostáticos periodontais marginais.

É com esse raciocínio que sobressai a importância do tratamento adequado da superfície radicular de pacientes periodontalmente envolvidos, tratamento esse ainda amplamente discutido na literatura, que até hoje não apresentou consenso formal. Embora muitos princípios filosóficos tenham sido expressos, a grande variabilidade de opiniões parece ser fator suficiente para denotar que ainda não se chegou a uma técnica precisa e definida de tratamento da superfície radicular, razão pela qual se justifica o presente trabalho, mesmo porque, conforme PASSANEZI" "Em ciência ninguém é dono da verdade!!!".

* PASSANEZI E. - Faculdade de Odontologia de Bauru/USP. Disciplina de Periodontia. 2002 
A importância do tratamento adequado da raiz pode ser extrapolada de trabalhos em nível ultra-estrutural ${ }^{27,58}$ e óptico ${ }^{42}$, que observaram alterações na estrutura da superfície dental no ambiente da bolsa, dando algum suporte à proposta de $\mathrm{KROMER}^{36}$ de ser recomendável a obtenção de superfície lisa e dura ("estéril").

Aliás, COGEN et al. ${ }^{15}$, ao submeterem dentes extraídos por razões periodontais e não tratados à cultura de células, não encontraram adesão e crescimento celular sobre raízes, evidenciando o efeito biológico adverso da superfície dental não tratada.

Assim, no presente trabalho procurourse analisar os efeitos de diferentes procedimentos de raspagem, isolados ou combinados e com ou sem condicionamento da superfície, para o tratamento adequado da raiz, cuja avaliação foi feita pela análise desses diferentes efeitos sobre a superfície radicular, como discutido a seguir.

Para possibilitar a padronização dos critérios utilizados no levantamento das variáveis utilizourse a proposta de LIE; MEYER ${ }^{37}$; MEYER; $\mathrm{LIE}^{40}$, que padronizou escores para cada uma dessas variáveis, conforme apresentado no capítulo de material e métodos.

Saliente-se que a instrumentação e análise foram feitas por profissional especialista na área, devidamente calibrado, com a finalidade de evitar a introdução de variações inter-examinadores, mesmo porque a realização dos procedimentos apresenta fatores de natureza subjetiva, que poderiam merecer a participação de muitos examinadores para validar a análise.

SCHLAGETER et al. $^{57}$, procurando padronizar rigorosamente a qualidade de execução dos procedimentos experimentais, também usaram um único profissional realizando todos os procedimentos.

Também O'LEARY; KAFRAWY ${ }^{47}$; BENFENATI et al. ${ }^{07}$; BUSSLINGER et al. ${ }^{10}$ destacaram a realização do procedimento de tratamento da raiz por um único operador, enquanto MOSKOW ${ }^{42}$ realizou a análise dos espécimes independentemente.

Mencione-se, de início, que a simples remoção das concreções e conseqüente exposição das raízes experimentais, permitindo o levantamento 
dos índices correspondentes às variáveis estudadas, é evidência cabal e inequívoca da efetividade dos procedimentos experimentais empregados.

A avaliação da quantidade de cálculo remanescente, rugosidade da superfície e perda de substância dentária foi baseada na inspeção visual em fotomicrografias e escores com os critérios definidos, método esse passível de erro inerente à subjetividade de seu julgamento. Todavia, comparando os dados obtidos por um único examinador por meio de dois exames feitos às cegas e em momentos diferentes, encontrou-se concordância satisfatória entre os 3 índices (Tabelas 1, 2 e 3), validando a confiabilidade das demais análises.

Relativamente à avaliação da eficiência dos procedimentos na remoção de cálculo, a análise das Tabelas 4 e 5 mostra que houve variação significante entre os grupos, enquanto a da Tabela 6 e da Figura 12 localizou a significância estatística da diferença entre os grupos 2 e 3 (ultra-som e ultra-som+cureta), 2 e 4 (ultra-som e cureta+ácido+cureta), 2 e 6 (ultra-som e ultra-som+ácido+cureta), 4 e 5 (cureta+ácido+cureta e ultra-som+ácido+ ultra-som) e 5 e 6 (ultra-som+ácido+ultra-som e ultra-som+ácido+cureta), ilustrando, também falta de diferenças significantes entre quaisquer outras combinações de tratamentos.

Esses resultados conduzem à inferência de que o US empregado isolado e o US+ácido+US, seguido de perto pelas curetas, foram os procedimentos que deixaram maior quantidade de cálculo residual (Figura 12), de modo que o emprego do ácido também não favoreceu significativamente a remoção do cálculo quando associado ao US, ficando também a impressão de que o US foi instrumento que removeu menos cálculo. Quando o ácido foi associado à cureta (grupo 4) ou ao ultra-som seguido pela cureta (grupo 6) aumentou a efetividade da remoção de cálculo. Isso parece demonstrar a existência de alguma variabilidade da efetividade de curetas e US, embora não significante entre si, porém sim em relação ao ultra-som isolado ou combinado com ácido cítrico.

Nesse sentido, os resultados apresentados na literatura têm sido até certo ponto conflitantes, embora na maioria concordantes com os resultados deste trabalho. 
Assim, DRAGOO ${ }^{19}$; YUKNA et al. ${ }^{67}$ encontraram menor quantidade de cálculo residual com o uso do US em vez de curetas. Entretanto, enquanto DRAGOO ${ }^{19}$ utilizou ponta ultra-sônica modificada, YUKNA et al. ${ }^{67}$ usaram ponta ultra-sônica diamantada, que podem ter aumentado a efetividade do instrumento.

Por outro lado, os resultados deste trabalho, são concordantes amplamente com os de STENDE; SCHAFFER ${ }^{61}$; MOSKOW; BRESSMAN ${ }^{41}$, WILKINSON; MAYBURY ${ }^{64}$; WOODRUFF et al. ${ }^{66}$; ESCHLER; RAPLEY ${ }^{20}$; JONES et al. ${ }^{33}$ e BUSSLINGER et al. ${ }^{10}$, para os quais a efetividade da cureta e do US é praticamente igual quanto à remoção de cálculo. Além disso, considerando a variabilidade do comportamento das amostras de tratamentos combinados nos quais houve a participação do uso das curetas, os resultados, de modo geral, também foram praticamente concordantes com os LIE ; MEYER ${ }^{37}$; MEYER; LIE ${ }^{40}$; HUNTER et al. ${ }^{30}$, BENFENATTI et al. ${ }^{07} \mathrm{e}$ KOCHER et al..$^{35}$, que encontraram superioridade das curetas em relação ao US, no que diz respeito ao ICR. Aliás para KOCHER et al. $^{35}$ a cureta praticamente não deixou cálculo ( $\mathrm{ICR}=2,5 \%)$, porém o US foi quase tão eficiente quanto as curetas (ICR=7,8\%).

Repita-se uma vez mais a tendência do ICR ser menor para as curetas do que US, embora sem diferença significante. Todavia, essa tendência pode ser vista quando se considera a significância de diferença dos resultados entre os grupos 2 e 3 e não significância entre 1 e 3.

Aliás a significância da diferença entre os grupos 2 e 3 e não significância entre 1 e 3 mostra que o emprego das curetas após o US conduz à melhoria na remoção de cálculo, o que é de se esperar porque ao US associou-se o emprego da cureta, que tem tendência de remover mais efetivamente o cálculo, de modo que, mesmo não havendo evidências definitivas da vantagem das curetas, a ação somada dos instrumentos produziu pelo menos a duplicação do número de golpes, favorecendo a remoção do cálculo. Todavia, para ESCHLER; RAPLEY ${ }^{20}$ a comparação entre o uso de cureta ou US com ponta convencional isoladamente ou US com pontas diamantadas+cureta seqüencialmente, ou US com ponta 
diamantada unicamente, mostrou a mesma efetividade na remoção de cálculo.

É mister ressaltar, entretanto, que estes autores não só se preocuparam com a variação na efetividade do US conforme a graduação da potência do aparelho usada, a força de pressão das pontas nas superfícies e do tempo de aplicação entre outros, como também utilizaram pontas ultrasônicas diamantadas para aumentar a efetividade.

Portanto, parece plausível considerar-se que os resultados obtidos conformam-se com a proposta de STENDE; SCHAFFER ${ }^{61}$; e GARRET ${ }^{24}$, segundo os quais a associação do emprego de US e cureta representou boa norma de instrumentação da superfície radicular quanto à remoção de cálculo.

Quando se relacionou a rugosidade superficial das raízes instrumentadas (IRS) entre os vários grupos a análise das Tabelas 7 e 8 mostra que houve variação significante entre os grupos, enquanto a Tabela 9 e a Figura 14 localizaram a significância estatística da diferença entre o grupo 2 (US) e os grupos 1 (cureta), 4 (cureta+ácido+cureta) e 6 (US+ácido+ cureta) e entre o grupo 5 (US+ácido+US) e os grupos 1 (cureta) e 6 (US+ácido+cureta), não se evidenciou diferenças estatisticamente significantes entre os grupos 1, 3, 4 e 6, entre os grupos 2 e 3 e os grupos 5 e 3.

Esses resultados parecem ilustrar que o emprego de curetas, isoladas ou combinadas com outras formas de instrumentação leva à obtenção de textura superficial mais lisa ou menos rugosa.

Essa observação fundamenta-se na inexistência de diferenças significantes entre os grupos 1, 3, 4 e 6 e entre os grupos 2 e 3 e 5 e 3, porém não significantes entre os grupos 3 e os demais, ou seja, os melhores resultados parecem manifestar-se nos grupos em que houve participação das curetas. Veja-se que, embora o grupo 3 não tenha apresentado diferenças significantes em relação aos grupos 2 e 5, que foram os de maior IRS, também não apresentaram em relação aos grupos 1, 4 e 6, que foram os de menor IRS. 
Analisando o comportamento dos grupos 2 e 5 observa-se que o uso do ácido não induziu melhora no IRS, evidentemente porque se fez uso do US como instrumentação final.

Por outro lado, a falta de diferença significante no IRS entre os grupos 2 e 3 denota que o emprego de curetas não foi suficiente para eliminar toda a rugosidade superficial produzida pelo US, que pode deixar marcas profundas da instrumentação até na dentina conforme LIE; MEYER ${ }^{37}$.

Entretanto, quando se compara o grupo 6 com o 2 observa-se que o condicionamento ácido influenciou significativamente o preparo da superfície dental quanto ao IRS, uma vez que a instrumentação com US seguida por instrumentação com curetas após condicionamento ácido produziu diferenças significativas nos resultados alcançados.

Quando se usou curetas isoladamente ou como último tipo de instrumentação em quaisquer das combinações não houve diferenças significantes, ilustrando a efetividade das curetas, conforme observado também por LEKNES et al. ${ }^{38}$.

A rugosidade da superfície radicular tem sido associada ao acúmulo de placa dentobacteriana e desenvolvimento da inflamação gengiva ${ }^{39,56,65}$, tendo sido a cureta mais efetiva na produção de superfícles lisas nos trabalhos de ALEO et al. ${ }^{04}$; BENFENATTI et al. ${ }^{07}$; BYE et al. ${ }^{11}$; GARRETT $^{24}$; HUNTER et al. ${ }^{30}$; MEYER; LIE ${ }^{40}$; ROSENBERG; ASH ${ }^{55}$; SCHLAGETER et al. ${ }^{57}$; VAN VOLKINBURG et al. ${ }^{63}$; WILKINSON; MAYBURY ${ }^{64}$; e YUKNA et al. ${ }^{67}$, concordantes, portanto, com os resultados do presente trabalho.

Cite-se, entretanto, que DRAGOO ${ }^{19}$ encontrou esta mesma correlação quando usou US com pontas convencionais, porém quando usou pontas modificadas, a lisura superficial foi mais efetiva com o seu uso. Também para MOSKOW; BRESSMAN ${ }^{41}$; PAMEIJER et al. ${ }^{48}$; e WOODRUFF $^{66}$ o uso de US foi mais efetivo que o de curetas, talvez evidenciando a variabilidade de adestramento individual no uso dos instrumentos, uma vez que estes autores usaram pontas convencionais de ultra-som.

Há que se ter em conta, ainda, que a textura superficial lisa deveria promover melhor prevenção da formação de placa dentobacteriana, o que 
não foi obtido no trabalho de ROSENBERG; $\mathrm{ASH}^{55}$, talvez pelo fato de que a amostra humana empregada não desenvolveu bons hábitos de higiene bucal.

Sendo assim, parece importante levar-se em conta que a textura superficial produzida apresenta biocompatibilidade celular, favorecendo a migração, adesão e proliferação de células na superfície dental.

Neste mister COGEN et al. ${ }^{15}$ observaram que raízes raspadas e aplainadas com curetas seguidas ou não pelo condicionamento ácido, permitiram igualmente adesão e crescimento de fibroblastos, o que não aconteceu em raízes não tratadas mecanicamente ou tatadas apenas por condicionamento ácido.

Por sua vez, ZAMAN et al. ${ }^{68}$ propuseram que a raspagem e aplainamento radicular de dentes periodontalmente envolvidos,quer deixe superfícies de cemento ou dentina expostas mediante instrumentação com curetas, permite a adesão e orientação de células, as quais se produzem melhor após a desmineralização.

Da mesma forma, SANT'ANA ${ }^{56}$ observou que a textura superficial produzida pelas curetas foi suficiente para tornar as superfícies tratadas receptivas à mobilização celular, que se tornou mais manifesta à aplicação de fatores de crescimento (PDGF, TGF e IGF) quando se fez a aplicação de ácido cítrico e tetraciclina após raspagem com curetas.

Apesar das diferenças estatísticas significantes deste trabalho em relação ao uso de curetas e US, a receptividade da superfície radicular após o uso do US também foi demonstrada no trabalho de GILMAN; MAXEY ${ }^{25}$. Entretanto, recentemente, BABAY ${ }^{05}$, tratando a superfície radicular com US até a obtenção de superfície lisa e plana, não encontraram receptividade biológica para migração de fibroblastos em cultura de células.

Ainda em relação à efetividade comparativa de curetas e US, BUSSLINGER et al. ${ }^{10}$; CHECCHI; PELLICCIONI ${ }^{13}$; e KOCHER et al. ${ }^{35}$ não encontraram variações significativas entre ambos os procedimentos.

Essa variabilidade de resultados dos diferentes autores provavelmente foi determinada não só por variações inter-examinadores, como também, pela variação nas intensidades das potências usadas no US e da aplicação das forças de instrumentação, além das características 
pertinentes ao instrumento em si e a amplitude e velocidade do movimento de trabalho executado $01,08,23,31$.

De qualquer forma algum grau de rugosidade parece ser necessário, uma vez que segundo BABAY ${ }^{05}$ as células aderem mais sobre superfícies ultra-estruturalmente rugosas do que lisas.

No que diz respeito ao IPSD, as Tabelas 10 e 11 e a Figura 16 permitem observar que não houve diferenças estatisticamente significantes entre os grupos, de modo que se suprimiu a aplicação do teste de Spearman.

Esses resultados parecem denotar que a calibração inicial de um único operador possibilitou padronização confiável do tratamento da raiz em relação aos vários requisitos propostos pela A.A.P. ${ }^{01}$ e por BJORN; LINDHE $^{08}$.

Veja-se que CLARK et al. ${ }^{14}$, observaram que em certas situações o emprego de potência média no US, bem como forças aplicadas de pequena magnitude resultaram em remoção mínima de estrutura dental em volume e profundidade.

Portanto, a perda de substância dental pode ser considerada semelhante entre os grupos, embora tenha sido irregular nos diferentes padrões, ora deixando cemento, ora expondo dentina, além de alterações na profundidade das estrias ou irregularidades produzidas (Vide Figura 15.A, 15.D e 15.F).

Em linhas gerais os resultados deste trabalho quanto ao IPSD são consensuais com aqueles de LIE; MEYER ${ }^{37}$; ESCHLER; RAPLEY ${ }^{20}$, porém não o são em relação aos trabalhos de JACOBSON et al. ${ }^{31}$; JONES et al. ${ }^{32}$; PAMEIJER et al. ${ }^{48}$; RITZ et al. ${ }^{53}$, para os quais o US remove menos quantidade de estrutura dental, contrariamente à proposta de BELTINE; SPUJT ${ }^{06}$ de que o US produz mais dano à superfície dental do que as curetas manuais.

Se, de um lado, isso poderia justificar a importância das curetas na preparação de superfícies lisas e planas ${ }^{24,10}$, de outro, parece indicativo da necessidade de melhor padronização dos procedimentos para obtenção de resultados similares como os obtidos no presente trabalho. 
Aliás, a padronização do uso dos diferentes instrumentais e técnicas tem sido amplamente ressaltada na literatura ${ }^{01,31,08,23,53,16}$, corroborando os resultados de ZAPPA et al. ${ }^{69}$, que encontraram aumento progressivo no IPSD com o aumento do número de golpes de instrumentação com curetas.

É de se ressaltar, contudo, que O'LEARY; KAFRAWY ${ }^{47}$ não conseguiram eliminar todo o cemento mesmo com a aplicação de 50 golpes de raspagem com diferentes tipos de curetas manuais.

Entretanto, a padronização de 30 golpes de instrumentação neste trabalho parece ter sido bem adequada, considera-se que em todas as situações propostas a quantidade de estrutura dental removida foi semelhante, não induzindo resultados significativamente diferentes entre os grupos.

Dessa forma, a análise conjunta dos parâmetros avaliados assume importância para o estabelecimento das várias correlações entre si e sua extrapolação clínica filosófica.

As correlações formuladas podem ser vistas nas Figuras 17 (ICR X IRS), 18 (ICR X IPSD) e 20 (IRS X IPSD), evidenciando correlação significativa entre ICR e IRS e ICR e IPSD, porém não significativa entre IRS e IPSD.

A correlação significativa entre ICR e IRS foi positiva, indicando que quanto menor o índice de cálculo residual, menor o índice de rugosidadde superficial, correspondendo, pois à superfície dental lisa.

Portanto, quando se analisa conjuntamente o ICR e o IRS observa-se que a utilização das curetas parece mais efetiva na somatória desses efeitos.

A correlação significativa entre ICR e IPSD foi negativa, ilustrando que à retenção de cálculo corresponde menor perda de substância dental, ou seja, quanto maior a raspagem, menor a quantidade de cálculo residual e maior remoção de estrutura dental.

É interessante observar, pois, que para quaisquer tipos de tratamento usado, deve-se proceder ao aumento da remoção de estrutura dental para que se possa obter redução na quantidade de cálculo residual

Essa correlação parece ser indicativa de que as curetas preencheram melhor o efeito conjugado, uma vez que foram os instrumentos que 
produziram menor ICR quaisquer que fossem as combinações terapêuticas empregadas, (Tabela 6, Figura 12), ao passo que quanto ao IPSD não houve diferença significante entre os procedimentos (Tabela 11 e Figura 16).

A significância dessas correlações se reveste de maior importância quando se considera que a padronização dos procedimentos pelo emprego de um único profissional calibrado, eliminou a influência de variáveis como sensibilidade tátil, força aplicada, princípios técnicos, enfim fatores inerentes ao operador $r^{08,20,23}$.

É interessante mencionar que MOSCOW ${ }^{42}$ aceitou a possibilidade de formação de cálculo no interior da substância radicular e propôs que pode haver formação de cálculo na junção cemento-dentina, na qual a fragmentação do cemento é mais freqüente no ambiente da bolsa. Aplainamento e alisamento completo da raiz até a dentina é, portanto, requerido quando se deseja remoção completa do acúmulo calcáreo, pois a remoção incompleta do cálculo pode atuar como núcleo de sedimentação de depósitos adicionais.

Essas observações explicariam porque no presente trabalho houve persistência de pontos focais de cálculo, uma vez que nem todo o cemento foi removido.

Talvez de forma incongruente, LIE; MEYER ${ }^{37}$ propuseram que 0 clínico deve procurar estabelecer superfícies radiculares biologicamente aceitáveis pela remoção apenas de tanta estrutura dental quanto necessária para a remoção completa do cálculo dental e criação de superfície dental lisa.

JONES; O'LEARY ${ }^{33}$ consideraram importante a remoção de todo o cemento quando a reinserção periodontal é desejada, não havendo razão para não se realizar aplainamento radicular vigoroso, uma vez que cemento pode se formar sobre dentina exposta ou cemento existente. Por isso mencionaram os relatos de Zander e de Levine de que uma superfície lisa, dura e limpa é mandatória para reinserção, pois cemento não se forma sobre superfície contaminada, a qual, por sua vez, funciona como corpo estranho.

Corroborando esses pontos de vista, HERTING ${ }^{27}$ propôs que a capacidade funcional ou habilidade funcional do tecido cementário somente pode ser restaurada se acreções, camadas superficiais alteradas de cemento 
e bactérias invasoras foram removidas por instrumentação vigorosa, de modo que a superfície fique formada por cemento normalmente estruturado.

Além desses aspectos é interessante observar pela análise conjunta das correlações elaboradas que, apesar de se encontrar correlação significante entre os ICR e IRS e ICR e IPSD, não se encontrou entre IRS e IPSD.

Considerando que houveram diferenças significantes de ICR e IRS, porém não de IPSD (Tabela 6, 9 e 11), talvez se pudesse inferir que o desgaste adicional produzido pelas diferentes composições terapêuticas não tenha levado à perda de substância dental de maneira substancial, provavelmente devido a possibilidade da existência de camadas de hipermineralização do cemento no ambiente da bolsa ${ }^{16,24,42,47,58,65}$.

Veja-se que houve tendência de se ter menor ICR e menor IRS quando se agregou o emprego do ácido.

Para RABBANI et al. ${ }^{52}$, a remoção de placa bacteriana e cálculo é importante aspecto de toda terapia periodontal.

Essas concepções e resultados alcançados merecem, pois, uma análise à luz de suas implicações clínicas e biológicas, com vistas à contribuição para vislumbrar a melhor conduta no que diz respeito à avaliação da efetividade do tratamento da raiz.

Dentro deste contexto há que se destacar inicialmente a correlação do efeito do tratamento da superfície dental com o objetivo proposto de cura da ferida cirúrgica, ou seja, se o propósito é a formação de epitélio juncional longo ou o estabelecimento de fibras de Sharpey, quer em processos de reinserção ou regeneração periodontal.

Conforme COLDIRON et al. ${ }^{16}$ o tratamento puro e simples da superfície dental por polimento usual é capaz de suprimir a camada de cemento impregnada por endotoxina, resultando em saúde periodontal clínica em animais e seres humanos, porém com resposta biológica em animais caracterizada predominantemente pela formação de epitélio juncional longo. Todavia, esses autores consideraram que 20 golpes de instrumentação são suficientes para remover todo o cemento, muito embora tenham encontrado cemento remanescente mesmo com 50 golpes. Em função desses eventos, 
consideraram haver evidências inconclusivas da relação entre rugosidade superficial e a resposta de dentes envolvidos periodontalmente ao passo que enfatizaram a necessidade de pelo menos 50 ou mais golpes de instrumentação para alcançar toda zona de penetração bacteriana e produzir 0 aplainamento radicular.

Enquanto NAKIB et al. ${ }^{43}$ consideraram a união de endotoxinas ao cemento náo só superficial, como fraca, NYMAN et al. ${ }^{46}$ (1988). encontraram o mesmo quadro de resposta periodontal ao tratamento radicular, quer removendo todo cemento ou não, porém mantendo visitas periódicas a cada 3 meses durante 2 anos. Provavelmente este trabalho foi desenvolvido em função dos resultados histológicos de estudo anterior de NYMAN et al. ${ }^{45}$, que sugeriram não ser necessária a remoção do cemento com o propósito de eliminar endotoxinas. para alcançar saúde periodontal, pois identificaram formação de epitélio juncional longo com tecido conjuntivo subjacente não inflamado, quer houvesse remoção ou não do cemento radicular previamente exposto.

Ademais e baseado nisso, o relatório da $A A^{01}$ de 2000 deixou implícito que a remoção completa de cálculo não é o objetivo obrigatório, pois requer instrumentação extensa e pode resultar em perda de quantidades significantes de cemento e dentina, induzindo hipersensibilidade dentinária e aumento da prevalência de pulpite., Some-se o fato de que a remoção intencional do cemento não foi incluída como desejável no tratamento periodontal, com o propósito de remover substâncias tóxicas da superfície radicular. Entretanto, enalteceram a importância da manutenção controlada para preservação da saúde periodontal.

É interessante ressaltar que DALY ${ }^{17}$ propôs a necessidade de eliminação completa do cemento, principalmente em função de ter encontrado invasão bacteriana na junção cemento-dentina na região radicular correspondente ao ambiente da bolsa e não puramente a presença de endotoxinas.

Corroborando estes achados, ADRIAENS et al. ${ }^{02}$ encontraram invasão bacteriana inclusive na área pulpar na região radicular exposta à bolsa, tendo considerado que as raízes de dentes potencialmente doentes 
poderiam atuar como reservatórios bacterianos ${ }^{07}$, a partir dos quais poderia ocorrer a recolonização da superfícies radiculares tratadas mecanicamente.

Mencione-se, uma vez mais, os achados de MOSKOW ${ }^{42}$ que implicaram a extensão do cálculo até a região da união cemento-dentina. Além disso, CHAVES et al. ${ }^{12}$ consideraram que, em nível ultra-estrutural, a superfície radicular apresenta estrutura mais complexa do que uma superfície aplainada e clinicamente lisa.

A par desses aspectos, GARRETT ${ }^{24}$ considerou que a única tendência clínica de que houve remoção de cálculo subgengival é a lisura superficial. Ainda mais, para alcançar reinserção ou nova inserção inferiu a importância do aplainamento radicular e até a remoção da camada de cemento hipermineralizado, que seria pré-requisito para desmineralização efetiva. Especula a possibilidade de que o colágeno radicular assim exposto poderia se fundir ao colágeno do tecido mole adjacente, proporcionando nova inserção de tecido conjuntivo.

Esses considerandos permitem inferir, pois, que a tendência é considerar a re-inserção o objetivo mais desejável a ser alcançado.

Assim, assume importância avaliar a resposta de biocompatibilidade da raiz principalmente à presença de fibroblastos, embora os resultados não sejam, conclusivos.

COGEN et al..$^{15}$ aceitaram que raízes aplainadas e desmineralizadas pareceram ser tão efetivas na promoção de adesão e crescimento de fibroblastos quanto aqueles tratados apenas por aplainamento radicular. Ressaltaram também que o tratamento por ácido cítrico somente promoveu adesão e crescimento celular quando realizado após aplainamento radicular, o que parece ser indicativo de incompatibilidade do cemento contaminado.

Também GILMAN; MAXEY25 não encontraram crescimento de fibroblastos em superfícies radiculares contaminadas por cálculo. $O$ fato de não haver crescimento ou viabilidade celular tanto sobre o fragmento radicular, como no meio de cultura, sugeriu ainda mais que a toxicidade do fragmento cálculo/ raiz atua perifericamente sobre o fibroblasto em cultura de tecido. Digno de menção foi o fato de terem reportado que o tratamento puro com US resultou em alguma efetividade no crescimento de fibroblastos, 
porém a morfologia e distribuição celulares foram irregulares, indicando provável efeito citopático de substâncias tóxicas remanescentes nos fragmentos radiculares tratados pelo US.

Trabalhando com células de ligamento periodontal humano, ZAMAN et al. ${ }^{68}$ consideraram, que, após desmineralização, o cemento pode propiciar superfície hospitaleira para migração, adesão e orientação daquelas células tanto quanto a dentina, tendo esse comportamento sido menos intenso quando fizeram apenas raspagem e aplainamento radicular. Fundamentados nessa observação reforçaram o ponto de vista de NYMAM et al. ${ }^{46}$ de que a remoção intencional excessiva de cemento durante aplainamento radicular com o propósito de eliminar endotoxina não é justificável.

Por sua vez, BABAY ${ }^{5}$ também encontrou efeito estimulante de atividades celulares biocompatíveis após a desmineralização de superfícies radiculares tratadas com curetas ou US. Entretanto, nos fragmentos não desmineralizados houve algum acúmulo de fibroblastos naquelas superfícies planas e lisas produzidas por curetas, o mesmo não ocorrendo nos fragmentos tratados com US. Dentro do nível ultra-estrutural a exposição da dentina e ampliação dos túbulos dentinários produziu superfícies rugosas que favoreceram o afluxo de maior número de fibroblastos do que superfícies apenas aplainadas (lisas).

Esses resultados parecem ser corroborados pelos achados de SANT'ANA ${ }^{56}$, que encontrou maior adesão e migração de fibroblastos de ligamento periodontal humano sobre fragmentos de dentes humanos periodontalmente doentes quando do tratamento mecânico da superfície dental seguiu-se a desmineralização com ácido cítrico/tetraciclina, acompanhados pela aplicação de fatores de crescimento (PDGF, TGF e IGF).

Esses considerandos parecem denotar que o tratamento radicular envolve o controle de fatores ainda indefinidos, mais do que simplesmente a presença de endotoxina contaminante.

Talvez seja nesse contexto que GARRETT ${ }^{24}$ tenha considerado que o único critério clínico disponível para indicar a remoção de cálculo subgebngival seja a lisura radicular, o que não pode ser tão preciso quanto 
se almeja ${ }^{59,12}$, pois neste trabalho e nos vários mencionados identificou -se cálculo em nível ultra-estrutural. ${ }^{34}$

Assim sendo, se o propósito terapêutico for o estabelecimento de epitélio juncional longo, parece sugestivo que se opte pela preservação de alguma camada de cemento, de modo a proteger mais estrutura dentinária/pulpar; se o propósito envolve reconstrução de fibras de Sharpey, parece mais salutar a remoção de maior quantidade de agentes irritativos, produção de superfície menos rugosa, reforçando a proposta de KROMER ${ }^{36}$, à qual se soma a possibilidade da ocorrência de eventos biológicos que favoreçam a re/nova inserção.

Ressalte-se, pois, que dentro desse contexto, o tratamento que combinou US+ácido+cureta foi o que produziu menor ICR, menor IRS e similar IPSD em relação aos demais grupos, enquanto que o US isolado ou combinado com ácido produziu os maiores ICR e IRS. Quanto às demais combinações, todas nas quais a cureta finalizou o procedimento produziram os menores ICR e IRS.

Sob esses aspectos a primeira combinação ou aquelas que finalizam com o uso de curetas parecem ser a ordem preferencial de tratamento, ou optando-se simplesmente pelo uso da cureta.

Embora a proposta de GARRETT ${ }^{24}$ seja essa análise das características superficiais como único meio de avaliação da efetividade do tratamento radicular, RABBANI et al. ${ }^{52}$ consideraram que os resultados poderiam ser melhorados se fossem repetidos os procedimentos de raspagem e aplainamento radiculares.

Ampliando o significado clínico biológico dessas propostas, PASSANEZl* ${ }^{*}$ defendeu o ponto de vista de que a avaliação da efetividade do procedimento de raspagem e aplainamento radicular não deve estar fundamentada apenas na análise da textura superficial, da raiz, mas principalmente na resposta gengival após 1 semana, traduzindo

\footnotetext{
** PASSANEZI E. Apresentação no Simpósio do Seminário Internacional de Periodontia. São Paulo, 1993.
} 
a manifestação de receptividade celular da raiz envolvida. Áreas com inflamação persistente requereriam novas instrumentações.

A viabilização clínica destas combinações com biomodificação por ácido é feita pela raspagem inicial com curetas isoladamente até obter-se resposta periodontal adequada, após o que, para os casos que necessitem tratamento cirúrgico, seguir-se-á o condicionamento ácido a campo aberto, raspagem com curetas e novo condicionamento para remoção da "smear layer" e, liberação de colágeno e/ou fatores de crescimento da superfície dental.

De qualquer maneira, embora os comentários apresentados tenham abordado uma complexidade de fatores, a definição exata da melhor maneira de tratamento da superfície radicular analisada merece novos estudos elucidativos. 


\section{CONCLUSÕES}

Por meio de aplicação de diferentes meios de instrumentação da superfície radicular, dentro da metodologia proposta, pôde-se concluir que:

1) A instrumentação da superfície radicular por meio de curetas ou US, associada ou não ao condicionamento ácido da raiz, não possibilita a remocão completa de cálculo;

2) A menor quantidade de cálculo residual é obtida quando se realiza a instrumentação inicial com US, seguindo-se desmineralização radicular e nova instrumentação com curetas. Em ordem crescente de cálculo residual seguem-se instrumentação com curetas+ácido+curetas, US+curetas, somente curetas, US+ácido+US e finalmente US;

3) A instrumentação manual com curetas, usadas após US+ácido, ou isoladamente, produz superfície radicular com textura mais lisa do que US isoladamente ou em associação ao ácido. Em ordem crescente de rugosidade superficial seguem-se a duplicação do uso de curetas, intercaladas pela aplicação do ácido e o uso de curetas após US;

4) A perda de substância dental produz-se de maneira uniforme para quaisquer tipos de tratamento realizado da superfície radicular, talvez devido ao aumento da resistência da estrutura dental à medida em que ele é desgastado; entretanto, áreas irregulares de cemento e/ou dentina são deixadas na supefície dental em nível ultra-estrutural;

5) O emprego de ácido intermediariamente entre instrumentações conjugadas favorece a remoção adicional de substância dental, conduzindo à obtenção de superfícies mais lisas e com menos cálculo residual;

6) As correlações entre os vários índices demonstra que a utilização das curetas isoladas ou após o uso do ultra-som, seguida ou não pelo condicionamento ácido, leva ao menor ICR e menor IRS; 
7) A correlação entre os índices mostra relação proporcional inversa significativa entre ICR e IPSD, significando que quanto maior o desgaste da superfície dental, menor a quantidade de cálculo remanescente. 


\section{REFERÊNCIAS BIBLIOGRÁFICAS*}

1 - AMERICAN ACADEMY of PERIODONTOLOGY. Sonic and ultrasonic scalers in periodontics. J. Periodont., v. 71, p. 1792-801, 2000.

2 - ADRIAENS, P.A., BOEVER, J.A. e LOESCHE, W.J. Bacterial invasion in root cementum and radicular dentin of periodontally diseased teeth in humans.- A reservoir of periodontopathic bacteria. J. Periodont., v. 59 , p. $222-30,1988$.

3 - ALEO, J.J. et al. The presence and bilogic activity of cementum-bound endotoxin. J. Periodont., n. 9, v. 45, p. 672-74, 1974.

4 - ALEO, J.J. et al. In vitro attachment of human gingival fibroblasts to root surfaces. J. Periodont., v. 46, p. 639-45, 1975.

5 - BABAY, N. Attachment of human gingival fibroblasts to periodontally involved root surface following scaling and/or etching procedures: a scanning electron study. Braz. dent. J., n. 1, v. 12, p. 17-21, 2001.

6 - BELTING, C.M. e SPJUT, P.J. Effects of high-speed periodontal instruments on the root surface during subgingival calculus removal. J. Amer. Dent. Ass. v. 69, p. 578-84, 1964.

7 - BENFENATI, M.P. et al. Scanning electron microscope: An SEM study of periodontally instrumented root surfaces, comparing sharp, dull and damaged curettes and ultrasonic instruments. Int. J. Periodont. Restorat. Dent., v. 7, n. 2, p. 51-67, 1987.

8 - BJORN, H. e LINDHE, J. The influence of periodontal instruments on the tooth surface. A methodological study. Odont. Revy., v. 13, p. 355-69, 1962.

9 - BLOMLÖF, J.P.S.; BLOMLÖF, L.B.; LINDSKOG, S.F., Smear layer formed by different root planing modalities and its removal by na ethylenediaminetetaracetic acid gel preparation. Int. J. Periodont. Restorat. Dent. v. 17, p. 243-49, 1997.

10 - BUSSLINGER, A. et al. A comparative in vitro study of a magnetostrictive and piezoelectric ultrasonic scaling instrument. J. Clin. Periodont., v. 28, p. 642-9, 2001.

11 - BYE, F.L., GHILZON, R.S., CAFFESSE, R.G. Root surface roughness after use of different modes of instrumentation. Int. J. Periodont. Restorat. Dent., v. 6, p. 37-47, 1986.

\footnotetext{
* Normas recomendadas para uso no âmbito da Universidade de São Paulo. Com base no documento "Referências Bibliográficas: exemplos", emanado do Conselho Supervisor do Sstema Integrado de Bibliotecas da USP, em reunião de 20 de setembro de 1990
} 
12 - CHAVES, E. et al. The effect of acid citric application on periodontally involved root surfaces. II. An in vitro scanning electron microscopy study. Int. J. Periodont. Restorat. Dent., v.13, p.189-96, 1993.

13 - CHECCHI, L., PELLICCIONI, G.A. Hand versus ultrasonic instrumentation in the removal of endotoxins from root surfaces in vitro. J. Periodont., v. 59, p. 398-402, 1988.

14 - CLARK, S.M., GRUPE, H.E. e MAHLER D.B. The effect of ultrasonic instrumentation on root surfaces. J. Periodont., v. 39, p.135-7, 1968.

15 - COGEN R.B., GARRISON, D.C. e WEATHERFORD, T.W. Effect of various root surface treatments on the viability and attachment of human gingival fibroblasts. J. Periodont., v. 54, p. 277-82, 1983.

16 - COLDIRON, N. et al. A quantitave study of cementum removal with hand curettes. J Periodont., v. 61, p. 293-9, 1990.

17 -DALY, C.G. Anti-bacterial effect of citric acid treatment of periodontally diseased root surfaces. J. clin. Periodont., v. 9, p. 386-92, 1982.

18 - DALY, C.G. et al. Histological assessment of periodontally involved cementum. J. clin. Periodont., v. 9, p. 266-74, 1982.

19 - DRAGOO, M.R. A clinical evaluation of hand and ultrasonic instruments on subgingival debridement. Part I. With unmodified and modified ultrasonic scalers inserts. Int. J. Periodont. Restorat. Dent., n. 4, v.12, p.311-23, 1992.

20 - ESCHLER, B.M., RAPLEY, J.W. Mechanical and chemical root preparation in vitro: efficiency of plaque and calculus removal. $\mathbf{J}$ Periodont., v. 62, p. 755-60, 1991.

21 - FEIST, I.S. Adesão e proliferação de fibroblastos de gengiva humana cultivados sobre superfície radiculares tratadas com laser de Er:YAG. São Paulo, 2002. 61p. Tese (Doutorado) Faculdade de Odontologia da Universidade de São Paulo, Universidade de São Paulo.

22 - FINE, D.H. et al. Preliminary characterization of material eluted from the roots of periodontally diseased teeth. J. Periodont. Res., v. 15, p. 109, 1980.

23 - FLEMMIG, T.F., et al. Working parameters of a magnetostrictive ultrasonic scaler influencing root substance removal in vitro. J. Periodont., v. 69, p. 547-53, 1998.

24 - GARRET, J.S. Root planing: a perspective. J Periodont. v. 48, p. 553-7, 1977 
25 - GILMAN R.S.; MAXEY B.R. The effect of root detoxification on human gingival fibroblasts. J. Periodont., v. 57, n. 7, p. 436-40, 1986.

26 -HATFIELD, C.G. e BAUMHAMMERS, A. Citotoxic effects of periodontally involved surfaces of human teeth. Arch. oral Biol., v.16, n. 4, p. 465-8, Apr., 1971.

27 -HERTING, H.C. Electron microscope studies of the cementum surface structures of periodontally healthy and diseased teeth. J. dent. Res. Supplement, v. 46, n. 6, p.1247, 1967.

28 - HUERZELER, M.B. et al. The effectiveness of different root debridement modalities in open flap surgery. J. clin. Periodont., v. 25, p. 202-8, 1998.

29 -HUGHES F.J. e SMALES F.C. The distribution and quantitation of cementum-bound lipopolysaccharide on periodontally diseased root surfaces of human teeth. Arch. oral Biol., n. 4, v. 35, p. 295-9, 1990.

30 - HUNTER, R.K., O'LEARY, T.J., KAFRAWY, A.H. The effectiveness of hand versus ultrasonic instrumentation in open flap root planing. $\mathbf{J}$. Periodont., v. 55, p. 697-703,1984.

31 - JACOBSON, L. et al. Root surface texture after different scaling modalities. Scand. J. dent. Res., v. 102, p. 156-60, 1994.

32 - JONES, S.J., LOZDAN, J., BOYDE, A. Tooth surfaces treated in situ with periodontal instruments. Brit. dent. J., v. 132, p. 57-64, 1972.

33 - JONES W.A. e O'LEARY T.J. The effectiveness of in vivo root planning. In: removing bacterial endotoxin from the roots of periodontally involved teeth. J. Periodont ., v. 49, n. 7, p. 337-42, 1978.

34 - KEPIC, T.J., O'LEARY, T.J., KAFRAWY, A.H. Total calculus removal: an attainable objective? J. Periodont., v. 61, p. 16-20, 1990.

35 - KOCHER, T.H. et al. Subgingival polishing with a Teflon-coated sonic scaler insert in comparasion to conventional instruments as assessed on extracted teeth. J. Clin. Periodont., v. 27, p. 243-49, 2000.

36 - KROMER, H. Implantation of bone homografts in periodontal pockets. Dent. Clin. N. Amer., v. 7, p. 471-83,1962.

37 - LIE, T., MEYER, K. Calculus removal and loss of tooth substance in response to different periodontal instruments - A scanning electron microscope study.. J Clin Periodont., v. 4, p. 250-62, 1977.

38 - LEKNES, K.N., et al. Influence of tooth instrumentation roughness on subgingival microbial colonization. J Periodont., v. 65, p. 303-8, 1994. 
39 - LÖE, H., THEILADE, E., and JENSEN, S.B. Experimental gingivitis in man. J. Periodont., v. 36, p. 177-87, 1965.

40 - MEYER, K., LIE, T. Root surface roughness in response to periodontal instrumentation studied by combined use of microroughness measurements and scanning electron microscopy. J. Clin. Periodont., v. 4, p. 77-91, 1977.

41 - MOSKOW, B.S. ; BRESSMAN, E. Cemental response - to ultrasonic and hand instrumentation. J. Amer. dent. Ass., v. 68, p. 698-703, 1964.

42 - MOSKOW, B.S. Calculus attachment in cemental separations. J. Periodont., v. 40, p.125-30, 1969.

43 - NAKIB, N.M. et al. Endotoxin penetration into root cementum of periodontally healthy and diseased human teeth. J. Periodont., v. 53, n. 6 , p. 368-78, 1982.

44 - NISHIMINE D. e O'LEARY T.J. Hand instrumentation versus ultrasonics in the removal of endotoxins from root surfaces. J. Periodont., v. 50, p. 345- 9, 1979.

45 - NYMAN, S. et al. Role of "diseased" root cementum in healing following treatment of periodontal disease. An experimental study in the dog. J. Periodont. Res., v. 21, p. 496-503, 1986.

46 - NYMAN et al. Role of "diseased" root cementum in healing following of periodontal disease. A clinical study. J. clin. Periodont., v. 15, p. 464-8, 1988.

47 - O'LEARY T.J. e KAFRAWY A.H. Total cementum removal: a realistic objective. J. Periodont., v. 54, p. 221-6, 1983.

48 - PAMEIJER, C.H., STALLARD, R.E. e HIEP, N. Surface characteristics of teeth following periodontal instrumentation: a scanning electron microscope study. J. Periodont., v. 43, p. 628-33, 1972

49 - PATTISON, G. L., PATTISON, A. M. Raspagem e alisamento radicular. In: _. Instrumentação em periodontia: orientação clínica. São Paulo: Medicina Panamericana, 1988. Cap.3, p.121-253.

50 - POLSON, A.M. The production of a root surface smear layer by instrumentation and its removal by citric acid. J. Periodont., v. 55, n. 8, p. 443-6, 1984.

51 - PITARU, S. ET AL. The influence of the morphological and chemical nature of dental surfaces on the migration, attachment, and orientation of human gingival fibroblasts in vitro. J. Periodont. Res., v. 19, p. 408$18,1984$. 
52 - RABBANI, G.M., ASH, M.M., CAFFESSE, R.G. The effectiveness of subgingival scaling and root planing in calculus removal. J Periodont., v. 52 , p. $119-23,1981$.

53 - RITZ, L.; HEFTI, A.F.; RATEITSCHAK, K.H. An in vitro investigation on the loss of root substance in scaling with various instrument. J. clin. Periodont., v. 18, p. 643-7, 1991

54 - RUBEN, M.P. e SHAPIRO, A. An analysis of root surface changes. In: periodontal disease - a review. J. Periodont., v. 49, p. 89-91, 1978.

55 - ROSENBERG, R.M., ASH JR., M.M. The effect of root roughness on plaque accumulation and gingival inflammation. J. Periodont. v. 45, n. 3, p. 146-150, Mar. 1974

56 - SANT'ANA, A.C.D. Efeitos da aplicação de diferentes fatores de crescimento (PDGF,-BB, IGF-1 e TGF-B1) isolados ou combinados na taxa de proliferação e na adesão de fibroblastos derivados de ligamento periodontal humano a fragmento radiculares tratados ou não com ácido cítrico e tetraciclina após raspagem. Bauru, 2001. 144p. Tese (Doutorado) - Faculdade de Odontologia de Bauru, Universidade de São Paulo.

57 - SCHLAGHTER, L.; RATEITSCHAK-PLUSS, E.M.; SCHWARZ, J.P. Root surface smoothness or roughness following open debridment. J. Clin. Periodont., v. 23, n. 5, p. 460-4. 1996.

58 -SELVIG, K. A. Ultrastructural changes in cementum and adjacent connective tissue in periodontal disease. Acta odont. scand., v. 24, p. 459.500, 1966.

59 - SHERMAN, P.R. et al. The effectiveness of subgingival scaling and root planning. I- Clinical detection of residual calculus. J. Periodont., v. 61, p. $3-8,1990$.

60 - SMART, G.J. et al. The assessment of ultrasonic root surface debridement by determination of residual endotoxin levels. J Clin Periodont., v. 17, p. 174-8, 1990.

61 - STENDE G.W. e SCHAFFER, E.M. A comparison of ultrasonic and hand scaling. J. Periodont., v. 32, p. 312-4, 1961.

62 - TANAKA, K., O'LEARY, T.J., KAFRAWY, A.H. The effect of acid citric on retained plaque and calculus. J. Periodont., v. 60, n. 2, p. 81-3, 1989.

63 - VAN VOLKINBURG, J.W., GREEN, E., ARMITAGE, G.C. The nature of root surfaces after curette, cavitron and alpha-sonic instrumentation. J. Periodont. Res., v. 11, p. 374-81, 1976. 
64 - WILKINSON, R.F. e MAYBURY, J.E. Scanning electron microscopy of the root surface following instrumentation. J. Periodont., v. 44, n. 9, p. 559-63, Sept. 1973.

65 - WIRTHLIN, M.R. et al. The hypermineralization of diseased root surfaces. J. Periodont., v. 50, n. 3, p. 125-7, 1997.

66 - WOODRUFF, H.C., LEVIN, M.P., BRADY, J.M. The effects of two ultrasonic instruments on root surfaces. J. Periodont., v. 46, p. 11926, 1975.

67 - YUKNA, R.A. et al. Clinical evaluation of the speed and effectiveness of subgingival calculus removal on single-rooted teeth with diamondcoated ultrasonic tips. J. Periodont., v. 68, p. 436-42, 1997.

68 - ZAMAN K.U. et al. A study of attached and oriented human periodontal ligament cells to periodontally diseased cementum and dentin after demineralizing with neutral e low $\mathrm{pH}$ etching solution. J. Periodont. v. 71, p. 1094-9, 2000.

69 - ZAPPA, U. et al. Root substance removal by scaling and root planning. J. Periodont., v. 62, n. 12, p. 750-54, 1991. 


\section{ABSTRACT \\ Evalution of root surface after manual and ultra-sonic instrumentation, following by a manual instumentation, utilizing mineralized and desmineralized teeth.}

The present work aimed at evaluating the effect of root treatment by instrumentation of not only mineralized teeth with curettes, ultra-sonics (US) and US followed by curettes, but also of teeth intermediately demineralized in combined instrumentations, by using citric acid and tetracycline. The dental surfaces were analysed on SEM by a unique examiner, being utilized 66 uniradicular teeth presenting calculus and thus indicating periodontal disease. The teeth were divided into 6 experimental groups with 10 teeth each and a control group consisting of 6 teeth with no treatment. The treatment protocol for the groups was as follows: group 1- mineralized teeth instrumented with curettes; group 2- mineralized teeth instrumented with US; group 3mineralized teeth instrumented with US, followed by curette; group 4 - teeth instrumented with curettes, demineralized and again instrumented with curettes; group 5 - teeth instrumented with US, demineralized and again instrumented with US; and, group 6- teeth instrumented with US, demineralized and instrumented with curettes. The amount of residual calculus $(\mathrm{RCl})$, roughness of the radicular surface (SRI) and loss of dental substance (LTSI) were assessed. The results demonstrated statistically significant differences regarding the $\mathrm{RCl}$ of group 2 in relation to groups 3,4 and 6 , and that of group 5 with groups 4 and 6; as for the SRI, there were statistically significant differences between group 2 and groups 1, 4 and 6, and between group 5 and groups 1 and 6; no statistically significant differences were observed for the LTSI among groups. The use of curettes, alone or following US, seems more suitable for the criteria of adequate root preparation, as a function of the parameters evaluated. 